University of Nebraska - Lincoln

DigitalCommons@University of Nebraska - Lincoln

November 2006

\title{
A REVIEW OF THE FAMILY-GROUP NAMES FOR THE SUPERFAMILY SCARABAEOIDEA (COLEOPTERA) WITH CORRECTIONS TO NOMENCLATURE AND A CURRENT CLASSIFICATION
}

Andrew B. T. Smith

University of Nebraska - Lincoln, asmith@unl.edu

Follow this and additional works at: https://digitalcommons.unl.edu/entomologypapers

Part of the Entomology Commons

Smith, Andrew B. T., "A REVIEW OF THE FAMILY-GROUP NAMES FOR THE SUPERFAMILY SCARABAEOIDEA (COLEOPTERA) WITH CORRECTIONS TO NOMENCLATURE AND A CURRENT CLASSIFICATION" (2006). Papers in Entomology. 122.

https://digitalcommons.unl.edu/entomologypapers/122

This Article is brought to you for free and open access by the Museum, University of Nebraska State at DigitalCommons@University of Nebraska - Lincoln. It has been accepted for inclusion in Papers in Entomology by an authorized administrator of DigitalCommons@University of Nebraska - Lincoln. 


\title{
A Review of the Family-Group Names for the Superfamily Scarabaeoidea (Coleoptera) with Corrections to Nomenclature and a Current Classification
}

\author{
Andrew B. T. SMith \\ Canadian Museum of Nature, P.O. Box 3443, Station D \\ Ottawa, ON K1P 6P4, CANADA \\ asmith@mus-nature.ca
}

\begin{abstract}
For the first time, all family-group names in the superfamily Scarabaeoidea (Coleoptera) are evaluated using the International Code of Zoological Nomenclature to determine their availability and validity. A total of 383 family-group names were found to be available, and all are reviewed to scrutinize the correct spelling, author, date, nomenclatural availability and validity, and current classification status. Numerous corrections are given to various errors that are commonly perpetuated in the literature. A reversal of precedence is used to preserve the prevailing usage of the following family-group names: Eupariini Schmidt, 1910 (over Ataeniini Harold, 1868); Pachydemini Burmeister, 1855 (over Elaphocerini Blanchard, 1851); Heterosternina Bates, 1888 (over Macropnina Horn, 1866); and Anomalina Streubel, 1839 (over Euchlorina Hope, 1839).
\end{abstract}

Houston, we've had a problem here -Apollo 13 Astronaut Jack Swigert

13 April 1970

Trust No One

-X-Files mantra

Recently, there has been an effort to investigate and modernize the familygroup names for many taxa. Within Coleoptera, family-group names have been evaluated and listed for Geodephaga (Madge 1989), Staphyliniformia (Newton and Thayer 1992), Cucujoidea (Pakaluk et al. 1994), Tenebrionidae (Bouchard et al. 2005), and Curculionoidea (Alonso-Zarazaga and Lyal 1999). Lawrence and Newton (1995) also summarized all of the family and subfamilies of Coleoptera recognized in their classification. Until now, there has never been a serious effort to evaluate all the Scarabaeoidea family-group names using the International Code of Zoological Nomenclature (hereafter called the ICZN) (International Commission on Zoological Nomenclature 1999). Consequently, the state of affairs has been a disastrous mess! In this paper, all family-group names in the superfamily Scarabaeoidea that are available under the ICZN are listed with their current status (valid or invalid), original spelling, and type genus. Unavailable family-group names (nomina nuda, etc.) are not extensively reviewed in this paper, but some of the notable and/or better-known examples are briefly discussed.

Usage of family-group names in Scarabaeoidea follows the conventions of most other Coleoptera with taxa recognized at the levels of superfamily, family, subfamily, tribe, and subtribe. A total of 383 family-group names have been established for Scarabaeoidea in a code-compliant manner. In this paper, 12 families, 43 subfamilies, 118 tribes, and 94 subtribes are recognized as valid. 
The purpose of this paper is to review the nomenclatural status and classification of all Scarabaeoidea family-group names. All names found were evaluated using the ICZN to determine if they were available for use. The ICZN was also used to determine the correct spelling, author, and date of all names. Then the current literature was consulted to determine and extrapolate what names were valid, what rank they should be classified at, and synonymy with other taxa. All of this information is summarized in the catalog below.

During the course of my research on Scarabaeoidea family-group names it was obvious that many family-group name nomenclatural acts lay hidden in old and sometimes obscure publications. I fully expect that a few additions and corrections will need to be made as more of these nomenclatural acts are rediscovered.

\section{Family-Group Names and the ICZN}

There is a specific set of rules in place for the validation of family-group names under the ICZN. For new names (published from 2000 to the present), the basic criteria for publication and derivation of the name must be met. Family-group names must be based on a valid genus within that family-group taxon, they must be explicitly indicated as intentionally new, and the type genus must be explicitly stated. The name must be formed using a stem based on the type genus (for example Lucan- for Lucanus) and a suffix for the appropriate family-group rank (-oidea for a superfamily, -idae for a family, -inae for a subfamily, -ini for a tribe, and -ina for a subtribe). Generally, the stem of a family-group name is formed by deleting the case ending of the appropriate genitive singular of a Greek, Latin, or Latinized genus-group name (for example: Scarabae- for Scarabaeus, Belohin- for Belohina, Aegiali- for Aegialia, etc.). However, this is not always straightforward (for example: Trog- for Trox, Heteronych- for Heteronyx, Osmodermat- for Osmoderma, etc.). Article 29 of the ICZN and Greek and Latin dictionaries should be carefully consulted before publishing new family-group names. Note that the stem of a family-group name must always be emended if the spelling of the type genus is altered or found to be incorrect.

When evaluating names that were published in the past, different rules apply for different periods of time. Some of the most relevant examples follow below. The dates below are explicitly cited in the current edition of the rules of nomeclature (ICZN 1999). Only the current edition of the rules of nomenclature should be used to evaluate names because this version overrides all previous versions.

1758-1900: Family-group names first published during this period in vernacular (nonLatinized) form (for example: Bolbocéraires, Pachypoden, Chasmatoptérides, etc.) are permitted only when they were subsequently Latinized and generally accepted as valid dating from the first publication in non-Latinized form. Latinized family-group names are available simply from their use during this period. No descriptions, definitions, or indications are necessary other than the requirement that the stem of the family-group name must be based on an available generic name.

1901-1930: Family-group names must be Latinized to be available during this period or any time later. Otherwise, a family-group name is available "by indication" simply by using an available generic name to form the stem. No description is necessary.

1931-1960: Family-group names must be accompanied by a description or definition (or bibliographic reference to such a published statement) that states characters that differentiate the taxon (unless the name is a replacement name). An exception to the preceding exists if a subsequent author validated the name from 1961-1999 using Article 13. 
The family-group name must also be based on a genus-group name that was considered to be valid and within that family-group taxon when it was first proposed.

1961-1999: Similar to 1931-1960 but without the Article 13 exception mentioned above.

There are many other rules regulating family-group names, and the ICZN (1999) should be consulted to determine the availability and validity of names previously published. Note that for family-group names published from 17581999, the stem can be emended if it was formed incorrectly (unless the incorrect version is in prevailing usage; see Article 29.5). For names published in 2000 or later, the stem should not be altered even if it was not formed correctly (Article 29.4).

The Principal of Priority (Article 23.1) generally applies to family-group names, but the rules are more flexible relative to generic and specific names. When it is discovered that a younger name is placed at a higher rank then an older name within that taxon, the older name should not replace the younger name if the younger name is in prevailing usage (Article 35.5) (for example: Melolonthidae Leach, 1819 containing Cetoniinae Leach, 1815 of some authors). The Principal of Homonymy applies to family-group names as with other names. If the stem of a family-group name is identical to the stem of another family-group name, the younger name is permanently invalid and must be replaced. Additionally, if the type genus of a family-group name is a junior homonym, the family-group name is permanently invalid and must be replaced.

Authorship of family-group names has been a source of confusion for some authors. According to the Principle of Coordination (Article 36), the author and date of a family-group name remains the same-even when the suffix must be changed when the taxon is raised or lowered in rank. For example, Geotrupidae Latreille, 1802; Geotrupinae Latreille, 1802; and Geotrupini Latreille, 1802 all simultaneously have the same author and date, regardless of what author first placed this family-group name at the family, subfamily, or tribal rank.

\section{Explanation of the Catalog Format}

The entries below are organized phylogenetically based largely on the current, prevailing classifications of the various groups. For many taxa, there have been recent overviews of the classification that were followed. Many other groups, however, have been sadly neglected when it comes to worldwide overviews of the classification (most notably Melolonthinae). For many of the more poorly known groups, it was necessary to use a patchwork of literature to try and piece together an overall classification. This was often complicated by the fact that authors working on the same groups do not always use the same classification scheme for their group, especially when determining the rank to use for a taxon. Although I had to make some of my own decisions about what classification scheme to use and what rank at which to place certain taxa, I think that the catalog below is a good reflection of the current literature. There are obvious problems with some groups, but these are beyond the scope of this paper. It is my hope that this review of scarab family-group names will be a catalyst for others to critically review and research higher-level scarab classification. The following works were used as a basis for the classification and phylogenetic order of some of the major groups of Scarabaeoidea: Scarabaeoidea-Browne and Scholtz 1995, Lawrence and Newton 1995; Passalidae-Boucher 2005; Ochodaeidae-Scholtz et al. 1988; Hybosoridae-Ocampo 2006; Scarabaeidae-Browne and Scholtz 1995, Ratcliffe et al. 2002; Aphodiinae-Dellacasa 1988; Scarabaeinae-Cambefort 1991; Melo- 
lonthinae-Britton 1957, Evans 2003; Rutelinae-Machatschke 1972, Jameson 1998; Dynastinae-Endrödi 1985; and Cetoniinae-Krikken 1984, Ratcliffe et al. 2002. Although the works above were used as a starting point, there are obvious problems and omissions in many of them, and several modifications were necessary based on more recently published papers. The classification of the families Geotrupidae and Lucanidae is more problematic. Because of the numerous and widely differing opinions about relationships within each of these groups, it was impossible to pick a single reference as the authority on either group. Therefore, I decided to take a somewhat conservative approach for each with some consideration given to molecular phylogenetics results (Smith et al. 2006). The Geotrupidae (including Bolboceratinae) were divided into three subfamilies with Bolboceratinae and Geotrupinae each further divided into several tribes loosely based on works such as Zunino (1984) and Nikolajev (2003). It is clear that more phylogenetics research must be done on this group before a strongly supported classification scheme can emerge for this group. Similarly, the family Lucanidae is in a state of taxonomic chaos at the higher levels. I based the classification loosely on Holloway $(1968,1997)$ and Howden and Lawrence (1974). The tribal classification within the subfamily Lucaninae was so haphazard that I decided to not recognize any of them in this work, even though there is undoubtedly merit in recognizing some of the groups as tribes (for example Platycerini, Chiasognathini, and Figulini). Since my expertise on this group is limited, I will leave it to future lucanid workers to develop a reasonable tribal classification scheme within the subfamily Lucaninae. Some of the phylogenetic order and classification decisions in this paper were based on a large-scale molecular phylogenetics project currently underway on Scarabaeoidea (introduced in Smith et al. 2006). Molecular data were only used in cases where there is no prevailing phylogenetic ordering or classification scheme used for a particular group. It should be noted that many more changes to higher-level scarab classification will be necessary once detailed reports on the findings of the molecular data are published. Until these detailed papers are published, I will refrain from making changes based solely on these findings.

Entries in the catalog are ordered by rank within a taxon, and there are multiple entries for family-group names with simultaneous ranks (for example: Scarabaeoidea: Scarabaeidae: Scarabaeinae: Scarabaeini). In cases where there are multiple entries, "Remarks" are most often given with highest ranked entry and synonyms are given only with the lowest ranked entry. Entries include the valid name for the taxon in bold followed by the original spelling and citation of the family-group name, the type genus, and when needed, remarks on the nomenclature or classification of the family-group or genus-group names dealt with in the entry. Any synonyms that exist for a taxon are also listed in separate entries after the entry for the valid name. Synonymy entries include the information mentioned above in addition to the correct stem and suffix for the taxonomic rank under which it is placed. An asterisk (*) indicates bibliographic references that I have not examined personally. The " $\uparrow$ " symbol indicates extinct fossil taxa.

\section{Superfamily SCARABaEOIDEA Latreille, 1802}

Original spelling and citation: Scarabæïdes Latreille 1802: 144

Type genus: Scarabaeus Linnaeus, 1758: 345

Remark: Scaraboides (von Laicharting 1781: II) was used prior to Latreille (1802) but does not fulfill the ICZN criteria for availability because it was used at the order rank not the family-group level. Scaraboides sensu von Laicharting was used as the name for all 
beetles ( $=$ order Coleoptera). This name has not been adapted at the order level and is unavailable at the family-group level (Article 1.2.2).

\section{Family Pleocomidae LeConte, 1861}

Original spelling and citation: Pleocomini LeConte 1861: 128

Type genus: Pleocoma LeConte, 1856: 24 (LeConte 1856b)

\section{Subfamily Pleocominae LeConte, 1861}

Original spelling and citation: Pleocomini LeConte 1861: 128

Type genus: Pleocoma LeConte, 1856: 24 (LeConte 1856b)

\section{$\dagger$ Subfamily Cretocominae Nikolajev, 2002}

Original spelling and citation: Cretocomini Nikolajev 2002a: 53

Type genus: Cretocoma Nikolajev, 2002: 54 (Nikolajev 2002a)

Family Geotrupidae Latreille, 1802

Original spelling and citation: Geotrupini Latreille 1802: 142

Type genus: Geotrupes Latreille, 1797: 6

\section{Subfamily Taurocerastinae Germain, 1897}

Original spelling and citation: Taurocerastidae Germain 1897: 287

Type genus: Taurocerastes Philippi, 1866: 115

\section{Subfamily Bolboceratinae Mulsant, 1842}

Original spelling and citation: Bolbocéraires Mulsant 1842: 347

Type genus: Bolboceras Kirby, 1819: 459 (Kirby 1819b)

Remark: Although this family-group name was not originally proposed in a Latinized form, it has subsequently been Latinized by numerous authors and should be considered available under Article 11.7.2.

\section{Tribe Bolboceratini Mulsant, 1842}

Original spelling and citation: Bolbocéraires Mulsant 1842: 347

Type genus: Bolboceras Kirby, 1819: 459 (Kirby 1819b)

\section{Tribe Athyreini Howden and Martínez, 1963}

Original spelling and citation: Athyreini Howden and Martínez 1963: 346

Type genus: Athyreus MacLeay, 1819: 123

Remark: Athyréites Blanchard 1845: 221 was not Latinized and was not subsequently Latinized until the tribe was formally described by Howden and Martínez (1963). Since Blanchard, 1845 has never been considered the author and date for this taxon, Article 11.7.2 does not apply and this family-group name should continue to be credited to Howden and Martínez, 1963. From the context of Blanchard (1845), all his "Famille" and "Groupe" names with the "-ides" and "ites" suffixes respectively are French vernacular names (some have accents).

\section{Tribe Bolвochromini Nikolajev, 1970}

Original spelling and citation: Bolbochromini Nikolajev 1970: 34

Type genus: Bolbochromus Boucomont, 1909: 117

Tribe GILLETININI Nikolajev, 1990

Original spelling and citation: Gilletinini Nikolajev 1990: 99

Type genus: Gilletinus Boucomont, 1932: 264

Tribe Eubolbitini Nikolajev, 1970

Original spelling and citation: Eubolbitini Nikolajev 1970: 33

Type genus: Eubolbitus Reitter, 1892: 125

\section{Tribe Bolbelasmini Nikolajev, 1996}

Original spelling and citation: Bolbelasmini Nikolajev 1996: 96

Type genus: Bolbelasmus Boucomont, 1911: 335 
Tribe Australobolbini Nikolajev, 1996

Original spelling and citation: Australobolbini Nikolajev 1996: 96

Type genus: Australobolbus Howden and Cooper, 1977: 19

Tribe Eucanthini Nikolajev, 2002

Original spelling and citation: Eucanthini Nikolajev 2002: 209 (Nikolajev 2002b)

Type genus: Eucanthus Westwood, 1848: 387 (Westwood 1848b)

Tribe STENaSPIDIINI Nikolajev, 2003

Original spelling and citation: Stenaspidiini Nikolajev 2003: 190

Type genus: Stenaspidius Westwood, 1848: 366 (Westwood 1848a)

Subfamily Geotrupinae Latreille, 1802

Original spelling and citation: Geotrupini Latreille 1802: 142

Type genus: Geotrupes Latreille, 1797: 6

Tribe Geotrupini Latreille, 1802

Original spelling and citation: Geotrupini Latreille 1802: 142

Type genus: Geotrupes Latreille, 1797: 6

$\dagger$ Tribe Cretogeotrupini Nikolajev, 1996

Original spelling and citation: Cretogeotrupini Nikolajev 1996: 97

Type genus: Cretogeotrupes Nikolajev, 1992: 80

Tribe Lethrini Mulsant and Rey, 1871

Original spelling and citation: Lethraires Mulsant and Rey 1871: 161

Type genus: Lethrus Scopoli, 1777: 439

Remark: Although this family-group name was not originally proposed in a Latinized form, it has subsequently been Latinized by numerous authors and should be considered available under Article 11.7.2.

\section{Tribe Chromogeotrupini Zunino, 1984}

Original spelling and citation: Chromogeotrupini Zunino 1984: 30

Type genus: Chromogeotrupes Bovo and Zunino, 1983: 404

Tribe Ceratotrupini Zunino, 1984

Original spelling and citation: Ceratotrupini Zunino 1984: 89

Type genus: Ceratotrupes Jekel, 1866: 540

\section{Family Belohinidae Paulian, 1959}

Original spelling and citation: Belohininae Paulian 1959: 40

Type genus: Belohina Paulian, 1959: 42

\section{Family Passalidae Leach, 1815}

Original spelling and citation: Passalida Leach 1815a: 100

Type genus: Passalus Fabricius, 1792: XI

\section{Subfamily Aulacocyclinae Kaup, 1868}

Original spelling and citation: Aulacocyclinae Kaup 1868a: 4

Type genus: Aulacocyclus Kaup, 1868: 4 (Kaup 1868a)

\section{Tribe Aulacocyclini Kaup, 1868}

Original spelling and citation: Aulacocyclinae Kaup 1868a: 4

Type genus: Aulacocyclus Kaup, 1868: 4 (Kaup 1868a)

Tribe Ceracupini Boucher, 2005

Original spelling and citation: Ceracupini Boucher 2005: 319

Type genus: Ceracupes Kaup, 1871: 16

\section{Subfamily Passalinae Leach, 1815}

Original spelling and citation: Passalida Leach 1815a: 100

Type genus: Passalus Fabricius, 1792: XI 


\section{Tribe Proculini Kaup, 1868}

Original spelling and citation: Proculinae Kaup 1868b: 8

Type genus: Proculus Kaup, 1868: 8 (Kaup 1868b)

Synonym: Pseudacanthini Kaup, 1871

Original spelling and citation: Pseudacantheae Kaup 1871: 73

Type genus: Pseudacanthus Kaup, 1869: 9

Synonym: Oileini Kuwert, 1891

Original spelling and citation: Oileinae Kuwert 1891: 192

Type genus: Oileus Kaup, 1869: 3

Synonym: Sertoriini Kuwert, 1891

Original spelling and citation: Sertorinae Kuwert 1891: 175

Type genus: Sertorius Kaup, 1871: 114

Remark: This family-group name is permanently invalid because the type genus,

Sertorius Kaup, 1871, is a junior homonym of Sertorius Stål, 1866 (Hemiptera)

(Article 39). Arrox Zang, 1905 was proposed as a replacement name for Sertorius Kaup, 1871.

Synonym: Unduliferini Kuwert, 1891

Original spelling and citation: Unduliferinae Kuwert 1891: 176

Type genus: Undulifer Kaup, 1869: 6

Synonym: Veturiini Kuwert, 1891

Original spelling and citation: Veturinae Kuwert 1891: 173

Type genus: Veturius Kaup, 1871: 110

Synonym: Popiliini Kuwert, 1896

Original spelling and citation: Popiliinae Kuwert 1896: 221

Type genus: Popilius Kaup, 1871: 75

Synonym: Proculejini Kuwert, 1896

Original spelling and citation: Proculejinae Kuwert 1896: 221

Type genus: Proculejus Kaup, 1868: 13 (Kaup 1868b)

Synonym: Spuriinae Kuwert, 1896

Original spelling and citation: Spuriinae Kuwert 1896: 221

Type genus: Spurius Kaup, 1871: 75

Synonym: Vindicini Kuwert, 1896

Original spelling and citation: Vindicinae Kuwert 1896: 227

Type genus: Vindex Kaup, 1871: 78

\section{Tribe Passalini Leach, 1815}

Original spelling and citation: Passalida Leach 1815a: 100

Type genus: Passalus Fabricius, 1792: XI

Synonym: Neleini Kaup, 1869

Original spelling and citation: Neleinae Kaup 1869: 28

Type genus: Neleus Kaup, 1869: 30

Remark: This family-group name is permanently invalid because the type genus, Neleus Kaup, 1869, is a junior homonym of Neleus Desbonne and Schramm, 1867 (Crustacea) (Article 39).

Synonym: Pertinacini Kaup, 1871

Original spelling and citation: Pertinaceae Kaup 1871: 89

Type genus: Pertinax Kaup, 1869: 21

Synonym: Phoroneini Kaup, 1871

Original spelling and citation: Phoroneae Kaup 1871: 97

Type genus: Phoroneus Kaup, 1869; 10 
Remark: This family-group name is permanently invalid because the type genus, Phoroneus Kaup, 1869, is a junior homonym of Phoroneus Stål, 1865 (Hemiptera) (Article 39). Macrolobus Zang, 1905 was proposed as a replacement name for Phoroneus Kaup, 1869.

Synonym: Mitrorhini Kuwert, 1891

Original spelling and citation: Mitrorhinae Kuwert 1891: 190

Type genus: Mitrorhinus Kaup, 1871: 79

Synonym: Paxillini Kuwert, 1891

Original spelling and citation: Paxillinae Kuwert 1891: 182

Type genus: Paxillus MacLeay, 1819: 105

Synonym: Petrejini Kuwert, 1891

Original spelling and citation: Petrejinae Kuwert 1891: 176

Type genus: Petrejus Kaup, 1869: 36

Synonym: Neleidini Kuwert, 1896

Original spelling and citation: Nelidinae Kuwert 1896: 222

Type genus: Neleides Kaup, 1869: 33

Synonym: Ptichopodini Kuwert, 1896

Original spelling and citation: Ptichopinae Kuwert 1896: 224

Type genus: Ptichopus Kaup, 1869: 27

Synonym: Rhodocanthopini Kuwert, 1896

Original spelling and citation: Rhodacanthopinae Kuwert 1896: 222

Type genus: Rhodocanthopus Kaup, 1871: 90

Synonym: Vatiniini Kuwert, 1896

Original spelling and citation: Vatiniinae Kuwert 1896: 226

Type genus: Vatinius Kaup, 1869: 35

Remark: This family-group name is permanently invalid because the type genus, Vatinius Kaup, 1869, is a junior homonym of Vatinius Stål, 1865 (Hemiptera) (Article 39). Zosterothrix Zang, 1905 was proposed as a replacement name for Vatinius Kaup, 1869.

\section{Tribe Solenocyclini Kaup, 1871}

Original spelling and citation: Solenocycleae Kaup 1871: 24

Type genus: Solenocyclus Kaup, 1868: 10 (Kaup 1868a)

Synonym: Eriocnemini Kaup, 1871

Original spelling and citation: Eriocnemiae Kaup 1871: 35

Type genus: Eriocnemis Kaup, 1868: 21 (Kaup 1868a)

Remark: This family-group name is permanently invalid because the type genus, Eriocnemis Kaup, 1868, is a junior homonym of Eriocnemis Reichenbach, 1849 (Aves) (Article 39). Gnaphalocnemis Heller, 1900 was proposed as a replacement name for Eriocnemis Kaup, 1868.

Synonym: Stephanocephalini Kaup, 1871: 78

Original spelling and citation: Stephanocephaleae Kaup 1871: 78

Type genus: Stephanocephalus Kaup, 1868: 19 (Kaup 1868b)

Synonym: Ciceroniini Kuwert, 1891

Original spelling and citation: Ciceroninae Kuwert 1891: 183

Type genus: Ciceronius Kaup, 1871: 29

Synonym: Erionomini Kuwert, 1891

Original spelling and citation: Erionominae Kuwert 1891: 176

Type genus: Erionomus Kaup, 1868: 16 (Kaup 1868a)

Synonym: Flaminiini Kuwert, 1891

Original spelling and citation: Flamininae Kuwert 1891: 185 
Type genus: Flaminius Kuwert, 1891: 185

Synonym: Semicyclini Kuwert, 1891

Original spelling and citation: Semicyclinae Kuwert 1891: 177

Type genus: Semicyclus Kaup, 1871: 28

Synonym: Gnaphalocnemini Gravely, 1914

Original spelling and citation: Gnaphalocneminae Gravely 1914: 194

Type genus: Gnaphalocnemis Heller, 1900: 10

Tribe Leptaulacini Kaup, 1871

Original spelling and citation: Leptaulaceae Kaup 1871: 28

Type genus: Leptaulax Kaup, 1868: 11 (Kaup 1868a)

Tribe MaCrolinini Kaup, 1871

Original spelling and citation: Macrolineae Kaup 1871: 42

Type genus: Macrolinus Kaup, 1868: 18 (Kaup 1868a)

Synonym: Aceraiini Kaup, 1871

Original spelling and citation: Aceraiae Kaup 1871: 47

Type genus: Aceraius Kaup, 1868: 26 (Kaup 1868a)

Synonym: Gonatini Kuwert, 1891

Original spelling and citation: Gonatinae Kuwert 1891: 169

Type genus: Gonatas Kaup, 1871: 50

Synonym: Mastachilini Kuwert, 1891

Original spelling and citation: Mastachilinae Kuwert 1891: 167

Type genus: Mastachilus Kaup, 1868: 19 (Kaup 1868a)

Synonym: Pharochilini Kuwert, 1891

Original spelling and citation: Pharochilinae Kuwert 1891: 166

Type genus: Pharochilus Kaup, 1868: 20 (Kaup 1868a)

Synonym: Tarquiniini Kuwert, 1891

Original spelling and citation: Tarquininae Kuwert 1891: 164

Type genus: Tarquinius Kuwert, 1891: 164

Synonym: Vellejini Kuwert, 1891

Original spelling and citation: Vellejinae Kuwert 1891: 167

Type genus: Vellejus Kaup, 1871: 35

Remark: This family-group name is permanently invalid because the type genus, Vellejus Kaup, 1871, is a junior homonym of Vellejus Mannerheim, 1830 (Coleoptera: Staphylinidae) and Vellejus Stål, 1865 (Hemiptera) (Article 39). Kaupiolus Zang, 1903 was proposed as a replacement name for Vellejus Kaup, 1871.

Synonym: Aureliini Kuwert, 1896

Original spelling and citation: Aureliinae Kuwert 1896: 230

Type genus: Aurelius Kuwert, 1891: 168

Synonym: Lachini Kuwert, 1896

Original spelling and citation: Lachinae Kuwert 1896: 230

Type genus: Laches Kaup, 1871: 48

Remark: This family-group name is permanently invalid because the type genus, Laches Kaup, 1871, is a junior homonym of Laches Gistl, 1848 (Hymenoptera) and Laches Thorell, 1869 (Arachnida) (Article 39). Chilomazus Zang, 1905 was proposed as a replacement name for Laches Kaup, 1871.

Synonym: Pelopini Kuwert, 1896

Original spelling and citation: Pelopinae Kuwert 1896: 229

Type genus: Pelopides Kuwert, 1896: 229 
Synonym: Pleurariini Kuwert, 1896

Original spelling and citation: Pleurariinae Kuwert 1896: 224

Type genus: Pleurarius Kaup, 1868: 1 (Kaup 1868b)

Synonym: Austropassalini Mjöberg, 1917

Original spelling and citation: Austropassalinae Mjöberg 1917: 11

Type genus: Austropassalus Mjöberg, 1917: 11

\section{Family Trogidae MacLeay, 1819}

Original spelling and citation: Trogidae MacLeay 1819: 59

Type genus: Trox Fabricius, 1775: 31

Subfamily Troginae MacLeay, 1819

Original spelling and citation: Trogidae MacLeay 1819: 59

Type genus: Trox Fabricius, 1775: 31

\section{Subfamily OMORgINAe Nikolajev, 2005}

Original spelling and citation: Omorgini Nikolajev 2005a: 322

Type genus: Omorgus Erichson, 1847: 107 (Erichson 1847a)

\section{Family GLARESIDAe Kolbe, 1905}

Original spelling and citation: Glaresini Kolbe 1905: 543

Type genus: Glaresis Erichson, 1848: 925

\section{Family Diphyllostomatidae Holloway, 1972}

Original spelling and citation: Diphyllostomatidae Holloway 1972: 38

Type genus: Diphyllostoma Fall, 1901: 324

\section{Family LuCANIDAe Latreille, 1804}

Original spelling and citation: Lucanides Latreille 1804: 234

Type genus: Lucanus Scopoli, 1763: 1

\section{Subfamily Aesalinae MacLeay, 1819}

Original spelling and citation: Aesalidae MacLeay 1819: 102

Type genus: Aesalus Fabricius, 1801: 254

\section{Tribe Aesalini MacLeay, 1819}

Original spelling and citation: Aesalidae MacLeay 1819: 102

Type genus: Aesalus Fabricius, 1801: 254

Tribe Ceratognathini Sharp, 1899

Original spelling and citation: Ceratognathini Sharp 1899: 194

Type genus: Ceratognathus Westwood, 1838: 260

Tribe Nicagini LeConte, 1861

Original spelling and citation: Nicagini LeConte 1861: 130

Type genus: Nicagus LeConte, 1861: 130

\section{Subfamily Syndesinae MacLeay, 1819}

Original spelling and citation: Syndesidae MacLeay 1819: 103

Type genus: Syndesus MacLeay, 1819: 104

Synonym: Sinodendrinae Mulsant, 1842

Original spelling and citation: Sinodendriens Mulsant 1842: 600

Type genus: Sinodendron Hellwig, 1792: 391

Remark: Although this family-group name was not originally proposed in a Latinized form, it has subsequently been Latinized by numerous authors and should be considered available under Article 11.7.2.

Synonym: Ceruchinae Jacquelin du Val and Fairmaire, 1859

Original spelling and citation: Ceruchites Jacquelin du Val and Fairmaire 1859: 4

Type genus: Ceruchus MacLeay, 1819: 115 
Remark: Although this family-group name was not originally proposed in a Latinized form, it has subsequently been Latinized by numerous authors and should be considered available under Article 11.7.2. From the context of Jacquelin du Val and Fairmaire (1859), all their "Groupe" names are French vernacular names (some have accents) even though they have the "-ites" suffix.

\section{Subfamily LaMpriminae MacLeay, 1819}

Original spelling and citation: Lamprimidae MacLeay 1819: 97

Type genus: Lamprima Latreille, 1804: 238

\section{Tribe LaMPrimini MacLeay, 1819}

Original spelling and citation: Lamprimidae MacLeay 1819: 97

Type genus: Lamprima Latreille, 1804: 238

\section{Tribe Streptocerini Kikuta, 1986}

Original spelling and citation: Streptocerini Kikuta 1986: 131

Type genus: Streptocerus Fairmaire, 1850: 53

\section{Subfamily LuCANINAE Latreille, 1804}

Original spelling and citation: Lucanides Latreille 1804: 234

Type genus: Lucanus Scopoli, 1763: 1

Remark: Several family-group names have been used for taxa within this subfamily that were never made available under the ICZN. These names were first used after 1930 but do not satisfy Article 13.1 (accompanied by a description or definition etc.): Aegini (Maes 1992b), Allotopini (Maes 1992a), Casignetini (Maes 1992b), Chalcodinae (Didier and Séguy 1953, Lacroix 1979), Colophonini (Maes 1992b), Cyclommatini (Maes 1992a), Homoderini (Maes 1992b), Neoprosopocoilini (Maes 1992b) (which is also not based on an available generic name), Nigidiini (Benesh 1960), Prosopocoilini (Benesh 1960), Pseudodorcini (Benesh 1960), and Rhyssonotini (Benesh 1960).

Synonym: Platycerinae Mulsant, 1842

Original spelling and citation: Platycéraires Mulsant 1842: 593

Type genus: Platycerus Geoffroy, 1762: 87

Remark: Although this family-group name was not originally proposed in a Latinized form, it has subsequently been Latinized by numerous authors and should be considered available under Article 11.7.2.

Synonym: Chiasognathinae Burmeister, 1847

Original spelling and citation: Chiasognathidae Burmeister 1847: 334

Type genus: Chiasognathus Stephens, 1831: 213

Synonym: Figulinae Burmeister, 1847

Original spelling and citation: Figulidae Burmeister 1847: 428

Type genus: Figulus MacLeay, 1819: 109

Synonym: Dorcinae Parry, 1864

Original spelling and citation: Dorcidae Parry 1864: 86

Type genus: Dorcus MacLeay, 1819: 111

Synonym: Cladognathinae Parry, 1870

Original spelling and citation: Cladognathidae Parry 1870: 75

Type genus: Cladognathus Burmeister, 1847: 364

Synonym: Odontolabinae Parry, 1870

Original spelling and citation: Odontolabidae Parry 1870: 106

Type genus: Odontolabis Hope, 1842: 247 (Hope 1842a)

Synonym: Rhaetulinae Miwa, 1931

Original spelling and citation: Rhaetulinae Miwa 1931: 323

Type genus: Rhaetulus Parry, 1871: 353 (Westwood 1871) 
Synonym: Systenocerinae Portevin, 1931

Original spelling and citation: Systenocerini Portevin 1931: 3

Type genus: Systenocerus Weise, 1883: 93 (Heyden et al. 1883)

Synonym: Penichrolucaninae Arrow, 1950

Original spelling and citation: Penichrolucaninae Arrow 1950: 233

Type genus: Penichrolucanus Deyrolle, 1863: 485

Synonym: Dendeziinae Benesh, 1955

Original spelling and citation: Dendeziini Benesh 1955b: 72

Type genus: Dendezia Basilewsky, 1952: 36

Synonym: Lissotinae Benesh, 1955

Original spelling and citation: Lissotini Benesh 1955b: 73

Type genus: Lissotes Westwood, 1855: 213

Synonym: Sclerostominae Benesh, 1955

Original spelling and citation: Sclerostomini Benesh 1955a: 97

Type genus: Sclerostomus Burmeister, 1847: 423

Synonym: Scortizinae Benesh, 1955

Original spelling and citation: Scortizini Benesh 1955a: 103

Type genus: Scortizus Westwood, 1834: 119

Synonym: Pholidotinae Kikuta, 1986

Original spelling and citation: Pholidotini Kikuta 1986: 131

Type genus: Pholidotus MacLeay, 1819: 97

Remark: This family-group name is permanently invalid because the type genus, Pholidotus MacLeay, 1819, is a junior homonym of Pholidotus Brisson, 1762 (Mammalia) (Article 39). Pholiodotus Hope, 1843 was proposed as a replacement name for Pholidotus MacLeay, 1819.

Synonym: Brasilucaninae Nikolajev, 1999

Original spelling and citation: Brasilucanini Nikolajev 1999a: 171

Type genus: Brasilucanus Vulcano and Pereira, 1961: 473

$†$ Subfamily Paralucaninae Nikolajev, 2000

Original spelling and citation: Paralucaninae Nikolajev 2000b: S328

Type genus: Paralucanus Nikolajev, 2000: S328 (Nikolajev 2000b)

Family OCHODAEIDAE Mulsant and Rey, 1871

Original spelling and citation: Ochodéens Mulsant and Rey 1871: 236

Type genus: Ochodaeus Dejean, 1821: 56

Remark: Although this family-group name was not originally proposed in a Latinized form, it has subsequently been Latinized by numerous authors and should be considered available under Article 11.7.2.

†Subfamily Cretochodaeinae Nikolajev, 1995

Original spelling and citation: Cretochodaeini Nikolajev 1995a: 78

Type genus: Cretochodaeus Nikolajev, 1995: 79 (Nikolajev 1995a)

\section{Subfamily OCHODaEINaE Mulsant and Rey, 1871}

Original spelling and citation: Ochodéens Mulsant and Rey 1871: 236

Type genus: Ochodaeus Dejean, 1821: 56

Tribe OCHOdaeini Mulsant and Rey, 1871

Original spelling and citation: Ochodéens Mulsant and Rey 1871: 236

Type genus: Ochodaeus Dejean, 1821: 56

\section{Tribe Enodognathini Scholtz, 1988}

Original spelling and citation: Endognathini Scholtz in Scholtz et al. 1988: 228

Type genus: Enodognathus Benderitter, 1920: 112 
Remark: Scholtz (1991) corrected Endognathini to Enodognathini to correct a misspelling of the type genus.

\section{Subfamily Chaetocanthinae Scholtz, 1988}

Original spelling and citation: Chaetocanthinae Scholtz in Scholtz et al. 1988: 231

Type genus: Chaetocanthus Péringuey, 1901: 495

\section{Tribe Chaetocanthini Scholtz, 1988}

Original spelling and citation: Chaetocanthini Scholtz in Scholtz et al. 1988: 231

Type genus: Chaetocanthus Péringuey, 1901: 495

\section{Tribe Pseudochodaeini Scholtz, 1988}

Original spelling and citation: Pseudochodaeini Scholtz in Scholtz et al. 1988: 235

Type genus: Pseudochodaeus Carlson and Ritcher, 1974: 99

\section{Tribe Synochodaeini Scholtz, 1988}

Original spelling and citation: Synochodaeini Scholtz in Scholtz et al. 1988: 237

Type genus: Synochodaeus Kolbe, 1907: 27

\section{Family Hybosoridae Erichson, 1847}

Original spelling and citation: Hybosoridae Erichson 1847a: 104

Type genus: Hybosorus MacLeay, 1819: 120

\section{Subfamily Anaidinae Nikolajev, 1996}

Original spelling and citation: Anaidini Nikolajev 1996: 94

Type genus: Anaides Westwood, 1842: 457 (Westwood 1842a)

Synonym: Cryptogeniinae Howden, 2001

Original spelling and citation: Cryptogeniini Howden 2001: 199

Type genus: Cryptogenius Westwood, 1842: 457 (Westwood 1842a)

\section{Subfamily Ceratocanthinae Martínez, 1968}

Original spelling and citation: Ceratocanthini Martínez 1968: 14

Type genus: Ceratocanthus White, 1842: 93

\section{Tribe Ceratocanthini Martínez, 1968}

Original spelling and citation: Ceratocanthini Martínez 1968: 14

Type genus: Ceratocanthus White, 1842: 93

Synonym: Acanthocerini Lacordaire, 1856

Original spelling and citation: Acanthocérides Lacordaire 1856: 155

Type genus: Acanthocerus MacLeay, 1819: 136

Remark: Although this family-group name was not originally proposed in a Latinized form, it has subsequently been Latinized by numerous authors and should be considered available under Article 11.7.2. This family-group name is permanently invalid because the type genus, Acanthocerus MacLeay, 1819, is a junior homonym of Acanthocerus Palisot de Beauvois, 1818 (Hemiptera) (Article 39). Ceratocanthus White, 1842 was proposed as a replacement name for Acanthocerus MacLeay, 1819.

Tribe Scarabatermitini Nikolajev, 1999

Original spelling and citation: Scarabatermitini Nikolajev 1999b: 175

Type genus: Scarabatermes Howden, 1973: 29

Tribe Ivieolini Howden and Gill, 2000

Original spelling and citation: Ivieolini Howden and Gill 2000: 315

Type genus: Ivieolus Howden and Gill, 1988: 2077

\section{Subfamily Hyвosorinae Erichson, 1847}

Original spelling and citation: Hybosoridae Erichson 1847a: 104

Type genus: Hybosorus MacLeay, 1819: 120 
Subfamily LiPAROCHRINAE Ocampo, 2006

Original spelling and citation: Liparochrinae Ocampo 2006: 29

Type genus: Liparochrus Erichson, 1848: 925

Subfamily Pachyplectrinae Ocampo, 2006

Original spelling and citation: Pachyplectrinae Ocampo 2006: 30

Type genus: Pachyplectrus LeConte, 1874: 53

Family GLAPHYRIDAE MacLeay, 1819

Original spelling and citation: Glaphyridae MacLeay 1819: 76

Type genus: Glaphyrus Latreille, 1802: 150

Subfamily GLaPhyrinae MacLeay, 1819

Original spelling and citation: Glaphyridae MacLeay 1819: 76

Type genus: Glaphyrus Latreille, 1802: 150

Remark: Amphicomites (Blanchard 1845: 211) was also used but was not subsequently Latinized and is therefore unavailable. From the context of Blanchard (1845), all his "Famille" and "Groupe" names with the "-ides" and "-ites" suffixes respectively are French vernacular names (some have accents).

$\dagger$ Subfamily CretoglaPHYRINAE Nikolajev, 2005

Original spelling and citation: Cretoglaphyrini Nikolajev 2005b: 70

Type genus: Cretoglaphyrus Nikolajev, 2005: 70 (Nikolajev 2005b)

Family SCARAbaEIDAE Latreille, 1802

Original spelling and citation: Scarabæïdes Latreille 1802: 144

Type genus: Scarabaeus Linnaeus, 1758: 345

†Subfamily LithoscarabaEINAE Nikolajev, 1992

Original spelling and citation: Lithoscarabaeinae Nikolajev 1992: 76

Type genus Lithoscarabaeus Nikolajev, 1992: 78

\section{Subfamily Chironinae Blanchard, 1845}

Original spelling and citation: Chironites Blanchard 1845: 225

Type genus: Chiron MacLeay, 1819: 107

Remark: Although this family-group name was not originally proposed in a Latinized form, it has subsequently been Latinized by numerous authors and should be considered available under Article 11.7.2. The stem of this family-group name may be formed incorrectly but this spelling is in prevailing usage and must be maintained (Article 29.5).

\section{Subfamily Aegialinae Laporte, 1840}

Original spelling and citation: Aegialites Laporte 1840: 99

Type genus: Aegialia Latreille, 1807: 96

Remark: Although this family-group name was not originally proposed in a Latinized form, it has subsequently been Latinized by numerous authors and should be considered available under Article 11.7.2.

Synonym: Silluviinae Landin, 1949

Original spelling and citation: Silluviinae Landin 1949: 3

Type genus: Silluvia Landin, 1949: 5

\section{Subfamily EremazinaE Iablokoff-Khnzorian, 1977}

Original spelling and citation: Eremazini Iablokoff-Khnzorian 1977: 168

Type genus: Eremazus Mulsant, 1851: 139

Remark: Eremazina (Stebnicka, 1977: 488) was also used in the same year but with a later publication date.

\section{Subfamily ApHodinae Leach, 1815}

Original spelling and citation: Aphodida Leach 1815a: 97

Type genus: Aphodius Illiger, 1798: 15 (Kugelann and Illiger 1798) 
Remark: Several family-group names have been used for taxa within this subfamily that were not originally Latinized and have not been subsequently Latinized and accepted as valid. These names (and others like them) are unavailable: Ammoeciates (Mulsant 1842: 301), Heptaulacates (Mulsant and Rey 1870: 385), Hexalates (Mulsant and Rey 1870: 385), Plagiogonates (Mulsant and Rey 1870: 609), and Pleurophorates (Mulsant 1842: 304).

Tribe ApHodinn Leach, 1815

Original spelling and citation: Aphodida Leach 1815a: 97

Type genus: Aphodius Illiger, 1798: 15 (Kugelann and Illiger 1798)

Subtribe ApHodina Leach, 1815

Original spelling and citation: Aphodida Leach 1815a: 97

Type genus: Aphodius Illiger, 1798: 15 (Kugelann and Illiger 1798)

\section{Subtribe Didactylinna Pittino, 1985}

Original spelling and citation: Didactyliina Pittino 1985: 270

Type genus: Didactylia d'Orbigny, 1896: 247

Subtribe Proctophanina Stebnicka and Howden, 1995

Original spelling and citation: Proctophanini Stebnicka and Howden 1995: 742

Type genus: Proctophanes Harold, 1861: 111

Tribe Corythoderini Schmidt, 1910

Original spelling and citation: Corythoderina Schmidt 1910: 137

Type genus: Corythoderus Klug, 1845: [8]

Tribe EupariINI Schmidt, 1910

Original spelling and citation: Eupariina Schmidt 1910: 102

Type genus: Euparia LePeletier and Serville, 1828: 357 (LePeletier and Serville, $1828 a)$

Synonym: Ataeniini Harold, 1868

Original spelling and citation: Ataenidae Harold 1868: 278

Type genus: Ataenius Harold, 1867: 82 (Harold 1867b)

Remark: Although Ataeniini has priority over Eupariini, the later is in prevailing usage and must be considered the valid using a reversal of precedence (Article 23.9). Ataeniini has not been used as a valid name since it was first proposed. Therefore, I invoke Article 23.9.2 and provide evidence that Eupariini has be used as a valid name in at least 25 works, published by at least 10 authors in the immediately preceding 50 years and encompassing a span of not less than 10 years. In compliance with the requirements of the Code, the following list of qualified publications, in chronological order, used Eupariini (with any recognized familygroup suffix) as a valid family-group name, which is sufficient evidence that it is in prevailing usage: Balthasar 1964; Cartwright 1977; Endrödi and Rakovič 1981; Chalumeau 1983; Ratcliffe 1991; Chalumeau 1992; Deloya 1994; Stebnicka and Howden 1996; Stebnicka 1997; Stebnicka 2001a; Stebnicka 2001b; Dellacasa and Stebnicka 2001; Martínez, Deloya, and Dellacasa 2001; Cruz and Martínez 2002; Skelley and Gordon 2002; Stebnicka 2002a; Stebnicka 2002b; Gordon and McCleve 2003; Stebnicka 2003a; Stebnicka 2003b; Stebnicka 2003c; Ordóñez Reséndiz and Deloya 2004; Stebnicka 2004; Masumoto and Ochi 2005; Smith 2005; Stebnicka 2005a; Stebnicka 2005b; and Stebnicka and Lago 2005.

Synonym: Lomanoxiini Stebnicka, 1999

Original spelling and citation: Lomanoxiini Stebnicka 1999: 280

Type genus: Lomanoxia Martínez, 1951: 29

Tribe Odontolochini Stebnicka and Howden, 1996

Original spelling and citation: Odontolochini Stebnicka and Howden 1996: 99

Type genus: Odontolochus Schmidt, 1916: 99 
Tribe Odochilini Rakovič, 1987

Original spelling and citation: Odochilini Rakovič 1987: 29

Type genus: Odochilus Harold, 1877: 97

Tribe Psammodini Mulsant, 1842

Original spelling and citation: Psammodiaires Mulsant 1842: 317

Type genus: Psammodius Fallén, 1807: 37

Remark: Although this family-group name was not originally proposed in a Latinized form, it has subsequently been Latinized by numerous authors and should be considered available under Article 11.7.2.

Subtribe Psammodina Mulsant, 1842

Original spelling and citation: Psammodiaires Mulsant 1842: 317

Type genus: Psammodius Fallén, 1807: 37

Synonym: Psammobiina Schmidt, 1910: 115

Original spelling and citation: Psammobiina Schmidt 1910: 115

Type genus: Psammobius Heer, 1841: 531

Subtribe Rhyssemina Pittino and Mariani, 1986

Original spelling and citation: Rhyssemina Pittino and Mariani 1986: 17

Type genus: Rhyssemus Mulsant, 1842: 314

\section{Tribe RHYParini Schmidt, 1910}

Original spelling and citation: Rhyparina Schmidt 1910: 130

Type genus: Rhyparus Westwood, 1845: xciii (Westwood 1845b*)

Remark: The original spelling of the type genus is Ryparus and Agassiz (1847) later made the unjustified emendation to Rhyparus. Since this unjustified emendation is in prevailing usage, it should be considered a justified emendation (Article 33.2.3.1). The emended spelling avoids homonymy with Ryparus Spinola, 1844 (Coleoptera: Cleridae). Rhyparus Westwood, 1845 is a senior homonym of Rhyparus Agassiz, 1847 (Coleoptera: Cleridae). The later name is an unjustified emendation of Ryparus Spinola, 1844 and is not in prevailing usage. Since the emended spelling is not in prevailing usage for the Cleridae name, Ryparus Spinola, 1844 and the Cleridae Rhyparus Agassiz, 1847 should both be treated as separate names.

Tribe Stereomerini Howden and Storey, 1992

Original spelling and citation: Stereomerini Howden and Storey 1992: 1811

Type genus: Stereomera Arrow, 1905: 534

Tribe TermitoderinI Tangelder and Krikken, 1982

Original spelling and citation: Termitoderini Tangelder and Krikken 1982: 10

Type genus: Termitoderus Mateu, 1966: 718

Tribe Thinorycterini Semenov-Tian-Shanskij and Reichardt, 1925

Original spelling and citation: Thinorycterina Semenov-Tian-Shanskij and Reichardt 1925: 86

Type genus: Thinorycter Semenov-Tian-Shanskij and Reichardt, 1925: 83

Tribe Phycochini Landin, 1960

Original spelling and citation: Phycochini Landin 1960: 59

Type genus: Phycochus Broun, 1886: 770

Subfamily Aulonocneminae Janssens, 1946

Original spelling and citation: Aulonocneminae Janssens 1946: 7

Type genus: Aulonocnemis Klug, 1838: 70

\section{Subfamily TERMITOTROGiNaE Wasmann, 1918}

Original spelling and citation: Termitotrogini Wasmann 1918: 4

Type genus: Termitotrox Reichensperger, 1915: 16 


\section{Subfamily SCARABaEINAE Latreille, 1802}

Original spelling and citation: Scarabæïdes Latreille 1802: 144

Type genus: Scarabaeus Linnaeus, 1758: 345

Tribe Eucranini Burmeister, 1873

Original spelling and citation: Eucraniadae Burmeister 1873: 405

Type genus: Eucranium Brullé, 1837: 289 (Audouin and Brullé 1837)

Synonym: Ennearabdini Pereira and Martínez, 1956

Original spelling and citation: Ennearabdini Pereira and Martínez 1956: 238.

Type genus: Ennearabdus van Lansberge, 1874: CXLIII (van Lansberge 1874a)

\section{Tribe Gymnopleurini Lacordaire, 1856}

Original spelling and citation: Gymnopleurides Lacordaire 1856: 72

Type genus: Gymnopleurus Illiger, 1803: 199

Remark: Although this family-group name was not originally proposed in a Latinized form, it has subsequently been Latinized by numerous authors and should be considered available under Article 11.7.2.

Tribe Eurysternini Vulcano, Martínez, and Pereira, 1961

Original spelling and citation: Eurysternini Vulcano, Martínez, and Pereira 1961: 268

Type genus: Eurysternus Dalman, 1824: 8

\section{Tribe Canthonini van Lansberge, 1874}

Original spelling and citation: Canthonides van Lansberge 1874b: 184

Type genus: Canthon Hoffmannsegg, 1817: 38

Remark: Although this family-group name was not originally proposed in a Latinized form, it has subsequently been Latinized by numerous authors and should be considered available under Article 11.7.2. Two family-group names have been used for taxa within this tribe that were not originally Latinized and have not been subsequently Latinized and accepted as valid. These names are unavailable: Epirinides (van Lansberge 1874b: 189) and Minthophilides (Lacordaire 1856: 80). From the context of van Lansberge (1874b), all his "tribu" names with the "-ides" suffix are French vernacular names (some have accents).

Synonym: Deltochilini Lacordaire, 1856

Original spelling and citation: Deltochilides Lacordaire, 1856: 78

Type genus: Deltochilum Eschscholtz, 1822: 37

Remark: Although this family-group name was not originally proposed in a Latinized form, it was subsequently Latinized by Germain (1903: 354) and should be considered available under Article 11.7.2. Although Deltochilini has priority over Canthonini, the latter is in prevailing usage at the tribal level and must not be displaced by the older name (Article 35.5).

Synonym: Epilissini van Lansberge, 1874

Original spelling and citation: Epilissides van Lansberge, 1874: 188 (van Lansberge $1874 b)$

Type genus: Epilissus Dejean, 1836: 151

Remark: Although this family-group name was not originally proposed in a Latinized form, it was subsequently been Latinized by Lebis (1953: 107) and should be considered available under Article 11.7.2.

Synonym: Panelini Arrow, 1931

Original spelling and citation: Panelini Arrow 1931: 404

Type genus: Panelus Lewis, 1895: 375

\section{Tribe Coprini Leach, 1815}

Original spelling and citation: Coprides Leach 1815a: 96

Type genus: Copris Geoffroy, 1762: 59 
Synonym: Coptodactylini Janssens, 1946

Original spelling and citation: Coptodactylides Janssens 1946: 13

Type genus: Coptodactyla Burmeister, 1846: [3]

Tribe Ateuchini Laporte, 1840

Original spelling and citation: Ateuchites Laporte 1840: 63

Type genus: Ateuchus Weber, 1801: 10

Remark: Although this family-group name was not originally proposed in a Latinized form, it has subsequently been Latinized by numerous authors and should be considered available under Article 11.7.2. Dichotomides (Halffter 1961: 228) and Dichotomiini (Halffter and Matthews 1966: 256) were used as a familygroup name for taxa within this tribe but neither was described or validated in any code compliant way, therefore the name is unavailable.

Synonym: Scatonomini Lacordaire, 1856

Original spelling and citation: Scatonomides Lacordaire, 1856: 87

Type genus: Scatonomus Erichson, 1835: 256

Remark: Although this family-group name was not originally proposed in a Latinized form, it was subsequently been Latinized by Harold (1867a: 9) and should be considered available under Article 11.7.2.

Synonym: Choeridiini Harold, 1867

Original spelling and citation: Choerididae Harold 1867a: 9

Type genus: Choeridium LePeletier and Serville, 1828: 536 (LePeletier and Serville, $1828 a)$

Synonym: Pinotini Kolbe, 1905

Original spelling and citation: Pinotinae Kolbe 1905: 548

Type genus: Pinotus Erichson, 1847: 108 (Erichson 1847a)

\section{Tribe Oniticellini Kolbe, 1905}

Original spelling and citation: Oniticellini Kolbe 1905: 547

Type genus: Oniticellus Dejean, 1821: 53

Subtribe Drepanocerina van Lansberge, 1875

Original spelling and citation: Drèpanocérides van Lansberge 1875: 14

Type genus: Drepanocerus Kirby, 1828: 521

Remark: Although this family-group name was not originally proposed in a Latinized form, it has subsequently been Latinized by numerous authors and should be considered available under Article 11.7.2. Although Drepanocerina has priority over Oniticellini, the later is in prevailing usage at the tribal level and must not be displaced by the older name (Article 35.5).

\section{Subtribe Oniticellina Kolbe, 1905}

Original spelling and citation: Oniticellini Kolbe 1905: 547

Type genus: Oniticellus Dejean, 1821: 53

\section{Subtribe Helictopleurina Janssens, 1946}

Original spelling and citation: Helictopleurides Janssens 1946: 11

Type genus: Helictopleurus d'Orbigny, 1915: 402

\section{Tribe ONITINI Laporte, 1840}

Original spelling and citation: Onitides Laporte 1840: 88

Type genus: Onitis Fabricius, 1798: 25

Remark: Although this family-group name was not originally proposed in a Latinized form, it has subsequently been Latinized by numerous authors and should be considered available under Article 11.7.2.

\section{Tribe Onthophagini Burmeister, 1846}

Original spelling and citation: Onthophagidae Burmeister 1846: [1]

Type genus: Onthophagus Latreille, 1802: 141 
Synonym: Alloscelini Janssens, 1946

Original spelling and citation: Alloscelides Janssens 1946: 10

Type genus: Alloscelus Boucomont, 1923: 1

Tribe Scarabaeini Latreille, 1802

Original spelling and citation: Scarabæïdes Latreille 1802: 144

Type genus: Scarabaeus Linnaeus, 1758: 345

Synonym: Pachysomatini Ferreira, 1953

Original spelling and citation: Pachysomides Ferreira, 1953: 8

Type genus: Pachysoma MacLeay, 1821: 507

Synonym: Actinophorini Ádám, 2003

Original spelling and citation: Actinophorini Ádám 2003: 130

Type genus: Actinophorus Creutzer, 1799: 79*

Remark: The genus Actinophorus is a junior synonym of Scarabaeus therefore the family-group name Actinophorini is a synonym of Scarabaeini.

Tribe Phanaeini Kolbe, 1905

Original spelling and citation: Phanaeinae Kolbe 1905: 550

Type genus: Phanaeus MacLeay, 1819: 124

\section{Tribe SisYPHINI Mulsant, 1842}

Original spelling and citation: Sisyphaires Mulsant 1842: 41

Type genus: Sisyphus Latreille, 1807: 79

Remark: Although this family-group name was not originally proposed in a Latinized form, it has subsequently been Latinized by numerous authors and should be considered available under Article 11.7.2. The original spelling of the type genus is Sisyphe, however, the incorrect subsequent spelling Sisyphus is in prevailing usage and should be considered the correct original spelling (Article 33.3.1).

$\nmid$ Subfamily Prototroginae Nikolajev, 2000

Original spelling and citation: Prototroginae Nikolajev 2000a: 63

Type genus: Prototrox Nikolajev, 2000: 65 (Nikolajev 2000a)

\section{$†$ Subfamily Cretoscarabaeinae Nikolajev, 1995}

Original spelling and citation: Cretoscarabaeinae Nikolajev 1995b: 147

Type genus: Cretoscarabaeus Nikolajev, 1995: 147 (Nikolajev 1995b)

\section{Subfamily Dynamopodinae Arrow, 1911}

Original spelling and citation: Dynamopinæ Arrow 1911b: 611

Type genus: Dynamopus Semenov-Tian-Shanskij, 1895: 336

Remark: Lawrence and Newton (1995) corrected the stem of this family-group name.

\section{Subfamily Phaenomeridinae Erichson, 1847}

Original spelling and citation: Phaenomerini Erichson 1847b: 655

Type genus: Phaenomeris Hope, 1833: 62

Remark: The International Commission on Zoological Nomenclature (1962) emended the stem of this family-group name from Phaenomer- to Phaenomerid- thus removing it from homonymy with another family-group name. In this ruling, "Ohaus, 1913" was erroneously given as the original author of this family-group name.

\section{Subfamily OrPhNINAE Erichson, 1847}

Original spelling and citation: Orphnidae Erichson 1847a: 111

Type genus: Orphnus MacLeay, 1819: 119

\section{Tribe ORPHNINI Erichson, 1847}

Original spelling and citation: Orphnidae Erichson 1847a: 111

Type genus: Orphnus MacLeay, 1819: 119 
Remark: Hybalites (Jacquelin du Val and Fairmaire 1859: 31) was used for taxa within this tribe but this family-group name was not originally Latinized and has not been subsequently Latinized and accepted as valid, therefore it is unavailable. From the context of Jacquelin du Val and Fairmaire (1859), all their "Groupe" names are French vernacular names (some have accents) even though they have the "-ites" suffix.

\section{Tribe Aegidinn Paulian, 1984}

Original spelling and citation: Aegidiinae Paulian 1984: 68

Type genus: Aegidium Westwood, 1845: 440 (Westwood 1845a)

Remark: The type genus was described three times in 1845 by Westwood (1845a: 440, 1845c: 158) and Blanchard (1845: 221). The earliest know publication dates for these papers are as follows: Westwood 1845a: 1 June 1845 (Evenhuis 2003), Blanchard 1845: 28 June 1845 (Evenhuis 1997), and Westwood 1845c: 25 November 1845 (Wheeler 1912). Therefore Westwood (1845a) has priority and must be considered the publication that first made Aegidium available under the ICZN.

\section{Subfamily Allidiostomatinae Arrow, 1940}

Original spelling and citation: Allidiostomidae Arrow 1940: 16

Type genus: Allidiostoma Arrow, 1940: 16

Remark: Lawrence and Newton (1995) corrected the stem of this family-group name.

Synonym: Idiostomatinae Arrow, 1904

Original spelling and citation: Idiostominae Arrow 1904: 747

Type genus: Idiostoma Arrow, 1904: 740

Remark: This family-group name is permanently invalid because the type genus, Idiostoma Arrow, 1904, is a junior homonym of Idiostoma Walsingham, 1882 (Lepidoptera) (Article 39). Allidiostoma Arrow, 1940 was proposed as a replacement name for Idiostoma Arrow, 1904.

\section{Subfamily AClopinae Blanchard, 1850}

Original spelling and citation: Aclopitae Blanchard 1850: 96

Type genus: Aclopus Erichson, 1835: 259

\section{Tribe ACLOPINI Blanchard, 1850}

Original spelling and citation: Aclopitae Blanchard 1850: 96

Type genus: Aclopus Erichson, 1835: 259

\section{Tribe Phaenognathini Iablokoff-Khnzorian, 1977}

Original spelling and citation: Phaenognathini Iablokoff-Khnzorian 1977: 137

Type genus: Phaenognatha Hope, 1842: 45 (Hope 1842b)

Remark: The genus was spelled Phaenognathus and Phaenognatha in the paper validating the name but the later spelling is in prevailing usage and is the correct spelling (Allsopp 1981).

\section{$\dagger$ Tribe HolcorobeINI Nikolajev, 1992}

Original spelling and citation: Holcorobeini Nikolajev 1992: 81

Type genus: Holcorobeus Nikritin, 1977: 127

Remark: The type genus was spelled both Holcorobeus (6 times) and Holcoribeus (1 time) in the paper containing the original description. Holcorobeus is obviously the intended spelling and has been adapted by subsequent authors, therefore this should be considered the correct spelling.

\section{Subfamily Melolonthinae Leach, 1819}

Original spelling and citation: Melolonthidæ Leach in Samouelle 1819: 189

Type genus: Melolontha Fabricius, 1775: 31

Remark: This family-group name was proposed in a publication by Samouelle (1819) but was attributed by Samouelle to Leach. Therefore Leach is the author of the name but "Leach in Samouelle" can also be used to facilitate information retrieval as 
suggested in Recommendation 51E of the ICZN. Leach (Samouelle 1819) and MacLeay (1819) both used Melolonthidae in the same year. Samouelle was published first (June 1819) and MacLeay later (November 1819) so Leach in Samouelle has priority and should be credited with authorship of this name. The publication dates of these references were reported in the "Catalogue of the Library of the Linnean Society" in Transactions of the Linnean Society and in Evenhuis (1997) (both from independent sources). The type genus, Melolontha Fabricius, 1775, is not a junior homonym of Melolontha Geoffroy, 1762. The Geoffroy name was suppressed for the purposes of the Principle of Priority and the Principle of Homonymy (ICZN 1994).

\section{Tribe Pachypodini Erichson, 1840}

Original spelling and citation: Pachypoden Erichson 1840: 29

Type genus: Pachypus Dejean, 1821: 57

Remark: Although this family-group name was not originally proposed in a Latinized form, it has subsequently been Latinized by numerous authors and should be considered available under Article 11.7.2. Billberg (1820: 390) used the name Pachypus prior to Dejean (1821), but this name was not made available under the ICZN in that publication. Therefore, Dejean (1821) is the author of the genus and it is not a junior homonym.

\section{Tribe LichniInI Burmeister, 1844}

Original spelling and citation: Lichniadae Burmeister 1844: 8

Type genus: Lichnia Erichson, 1835: 269

Tribe Euchirini Hope, 1840

Original spelling and citation: Eucheiridae Hope 1840: 300

Type genus: Euchirus Kirby, 1828: 636 (Kirby and Spence 1828)

Remark: The incorrect subsequent spelling Eucheirus originated with Hope (1837: 24) and should not be used.

Tribe Systellopini Sharp, 1877

Original spelling and citation: Systellopides Sharp 1877: 311

Type genus: Systellopus Sharp, 1877: 315

\section{Tribe Chasmatopterini Lacordaire, 1856}

Original spelling and citation: Chasmatoptérides Lacordaire 1856: 220

Type genus: Chasmatopterus Dejean, 1821: 60

Remark: Although this family-group name was not originally proposed in a Latinized form, it has subsequently been Latinized by numerous authors and should be considered available under Article 11.7.2.

\section{Tribe ONCERINI LeConte, 1861}

Original spelling and citation: Oncerini LeConte 1861: 133

Type genus: Oncerus LeConte, 1856: 283 (LeConte 1856a)

\section{Tribe Podolasinn Howden, 1997}

Original spelling and citation: Podolasiini Howden 1997: 224

Type genus: Podolasia Harold, 1869: 122

Synonym: Lasiopodini LeConte, 1856

Original spelling and citation: Lasiopodes LeConte 1856a: 282

Type genus: Lasiopus LeConte, 1856: 282 (LeConte 1856a)

Remark: This family-group name is permanently invalid because the type genus, Lasiopus LeConte, 1856, is a junior homonym of Lasiopus Schönherr, 1823 (Coleoptera: Curculionidae) and Lasiopus Geoffroy, 1835 (Mammalia) (Article 39). Podolasia Harold, 1869 was proposed as a replacement name for Lasiopus LeConte, 1856.

\section{Tribe Ablaberini Blanchard, 1850}

Original spelling and citation: Ablaberitae Blanchard 1850: 100

Type genus: Ablabera Dejean, 1833: 159 
Synonym: Camentini Machatschke, 1959

Original spelling and citation: Camentini Machatschke 1959: 743

Type genus: Camenta Erichson, 1847: 695 (Erichson 1847b)

Tribe SERICINI Kirby, 1837

Original spelling and citation: Sericidae Kirby 1837: 128

Type genus: Serica MacLeay, 1819: 146

Remark: Hope (1837) and Kirby (1837) both used Sericidae in the same year and the Hope (1837) paper refers to the Kirby (1837) paper. This is internal evidence in Hope (1837) that the Kirby (1837) paper was published first so Kirby should be credited with authorship of this family-group name.

\section{Subtribe Phyllotocina Burmeister, 1855}

Original spelling and citation: Phyllotocidae Burmeister 1855: 182

Type genus: Phyllotocus Fisher von Waldheim, 1823: 255

\section{Subtribe Sericina Kirby, 1837}

Original spelling and citation: Sericidae Kirby 1837: 128

Type genus: Serica MacLeay, 1819: 146

Remark: Omalopliites (Blanchard 1845: 212) was used for taxa within this tribe but this family-group name was not originally Latinized and has not been subsequently Latinized and accepted as valid, therefore it is unavailable. From the context of Blanchard (1845), all his "Famille" and "Groupe" names with the "-ides" and "-ites" suffixes respectively are French vernacular names (some have accents).

Synonym: Homalopliina Burmeister, 1855

Original spelling and citation: Homalopliadae Burmeister 1855: 147

Type genus: Homaloplia Agassiz, 1847: 258

Remark: The type genus is an unjustified emendation of Omaloplia Schönherr, 1817. Since the emended spelling is not in prevailing usage this name should be considered as a separate, available name. Erichson (1847b: 700) used Homaloplia in the same year as Agassiz (1847) but the exact publication dates of these works are unclear. Agassiz (1847) is dated 1846 on the cover page so I am assuming that it came out early in the following year.

Synonym: Astaenina Burmeister, 1855

Original spelling and citation: Astaenidae Burmeister 1855: 123

Type genus: Astaena Erichson, 1847: 101 (Erichson 1847a)

\section{Subtribe Trochalina Brenske, 1898}

Original spelling and citation: Trochalinae Brenske 1898: 354

Type genus: Trochalus Laporte, 1832: [1] (Laporte 1832c)

Tribe Phyllotocidinn Britton, 1957

Original spelling and citation: Phyllotocidiini Britton 1957: 9

Type genus: Phyllotocidium Blackburn, 1898: 24

\section{Tribe Diphucephalini Laporte, 1840}

Original spelling and citation: Diphucéphalites Laporte 1840: 145

Type genus: Diphucephala Dejean, 1821: 58

Remark: Although this family-group name was not originally proposed in a Latinized form, it has subsequently been Latinized by numerous authors and should be considered available under Article 11.7.2.

Tribe Comophorinini Britton, 1957

Original spelling and citation: Comophorini Britton 1957: 10

Type genus: Comophorina Strand, 1928: 3

\section{Tribe STETHaspini Burmeister, 1855}

Original spelling and citation: Stethaspididae Burmeister 1855: 218

Type genus: Stethaspis Hope, 1837: 40 
Remark: Although Stethaspini has not been used in any publication since before 1900 and Xylonichini has been used recently as a valid tribe, a reversal of precedence (Article 23.9) cannot be used to preserve the latter. Xylonichini has not been used as a valid name in at least 25 works published by at least 10 authors in the immediately preceding 50 years. Therefore, Stethaspini must be considered the valid name for this tribe.

Synonym: Xylonichini Britton, 1957

Original spelling and citation: Xylonychini Britton 1957: 9

Type genus: Xylonichus Boisduval, 1835: 186

Remark: Two spellings have been used for the type genus: Xylonichus, the original spelling and Xylonychus, an incorrect subsequent spelling. The incorrect subsequent spelling was used to form the family-group name. Since neither spelling is in prevailing usage (Britton 1957, Houston and Weir 1992) the original spelling should be used as the correct one. Therefore, the family-group name must be emended to match the original and correct spelling of the type genus (Article 35.4.1).

\section{Tribe Automolini Britton, 1978}

Original spelling and citation: Automoliini Britton 1978: 7

Type genus: Automolius Britton, 1978: 7

Remark: This genus-group name and family-group name are replacement names for Automolus Burmeister, 1855 (a junior homonym) and Automolini Britton, 1957.

Synonym: Caulobiini Burmeister, 1855

Original spelling and citation: Caulobiina Burmeister 1855: 204

Type genus: Caulobius Le Guillou, 1844: 224

Remark: This family-group name is permanently invalid because the type genus, Caulobius Le Gouillou, 1844, is a junior homonym of Caulobius Duponchel, 1838 (Lepidoptera) (Article 39). Deuterocaulobius Dalla Torre, 1912 was proposed as a replacement name for Caulobius Le Guillou, 1844.

Synonym: Automolini Britton, 1957

Original spelling and citation: Automolini Britton 1957: 9

Type genus: Automolus Burmeister, 1855: 202

Remark: This family-group name is permanently invalid because the type genus, Automolus Burmeister, 1855, is a junior homonym of Automolus Reichenbach, 1853 (Aves). Consequently the genus-group name and associated family-group name were both replaced by Britton (1978) (see Automoliini above).

\section{Tribe Maechidinn Burmeister, 1855}

Original spelling and citation: Maechidiina Burmeister 1855: 208

Type genus: Maechidius MacLeay, 1819: 140

\section{Tribe Liparetrini Burmeister, 1855}

Original spelling and citation: Liparetridae Burmeister 1855: 187

Type genus: Liparetrus Guérin-Méneville, 1831: 3

Synonym: Haplonychini Burmeister, 1855

Original spelling and citation: Haplonychidae Burmeister 1855: 224

Type genus: Haplonycha Dejean, 1836: 179

Remark: The original spelling of the type genus is Aplonycha but Agassiz (1847: 29) made the unjustified emendation to Haplonycha. Since this unjustified emendation is in prevailing usage, it should be considered a justified emendation (Article 33.2.3.1). Britton (1986) commented that this generic name was not made available from where it first appeared in text (in Dejean 1833). Although this is correct, Britton overlooked the next edition (Dejean 1836) of the Dejean catalogue, which does properly validate this name. Haplonycha Dejean, 1836 is currently considered to be a junior synonym of Colpochila Erichson, 1843. 
Synonym: Allarini Britton, 1955

Original spelling and citation: Allarini Britton 1955: 125

Type genus: Allara Britton, 1955: 124

Synonym: Colpochilini Britton, 1957

Original spelling and citation: Colpochilini Britton 1957: 10

Type genus: Colpochila Erichson, 1843: 195

\section{Tribe Scitalini Britton, 1957}

Original spelling and citation: Scitalini Britton 1957: 10

Type genus: Scitala Erichson, 1842; 166

Tribe Pachytrichini Burmeister, 1855

Original spelling and citation: Pachytrichiadae Burmeister 1855: 241

Type genus: Pachytricha Hope, 1841: 303

\section{Tribe SERICoIdini Erichson, 1847}

Original spelling and citation: Sericoideae Erichson 1847a: 102

Type genus: Sericoides Guérin-Méneville, 1840: 301

\section{Tribe Heteronychini Lacordaire, 1856}

Original spelling and citation: Hétéronychides Lacordaire 1856: 225

Type genus: Heteronyx Guérin-Méneville, 1831: 3

Remark: Although this family-group name was not originally proposed in a Latinized form, it has subsequently been Latinized by numerous authors and should be considered available under Article 11.7.2.

\section{Tribe Diplotaxini Kirby, 1837}

Original spelling and citation: Diplotaxidae Kirby 1837: 129

Type genus: Diplotaxis Kirby, 1837: 129

Synonym: Apogoniini Blanchard, 1851

Original spelling and citation: Apogoniitae Blanchard 1851: 228

Type genus: Apogonia Kirby, 1819: 401 (Kirby 1819a)

Synonym: Liogenini Blanchard, 1851

Original spelling and citation: Liogenitae Blanchard 1851: 166

Type genus: Liogenys Guérin-Méneville, 1831: 3

\section{Tribe Melolonthini Leach, 1819}

Original spelling and citation: Melolonthidæ Leach in Samouelle 1819: 189

Type genus: Melolontha Fabricius, 1775: 31

\section{Subtribe Schizonychina Burmeister, 1855}

Original spelling and citation: Schizonychidae Burmeister 1855: 265

Type genus: Schizonycha Dejean, 1833: 161

\section{Subtribe Enarinna Dewailly, 1950}

Original spelling and citation: Enarina Dewailly 1950: 323

Type genus: Enaria Erichson, 1847: 657 (Erichson 1847b)

\section{Subtribe Heptophyllina Medvedev, 1951}

Original spelling and citation: Heptophyllini Medvedev 1951: 197

Type genus: Heptophylla Motschulsky, 1858: 32

\section{Subtribe Pegylina Lacroix, 1989}

Original spelling and citation: Pegylini Lacroix 1989: 115

Type genus: Pegylis Erichson, 1847: 657 (Erichson 1847b)

\section{Subtribe Rhizotrogina Burmeister, 1855}

Original spelling and citation: Rhizotrogidae Burmeister 1855: 308

Type genus: Rhizotrogus Latreille, 1825: 371 
Remark: The original spelling of the type genus is Rhizotrogue but Berthold (1827) made the unjustified emendation to Rhizotrogus. Since this unjustified emendation is in prevailing usage, it should be considered a justified emendation (Article 33.2.3.1) (see Branco 2006 for more details).

Subtribe Leucopholina Burmeister, 1855

Original spelling and citation: Leucopholidae Burmeister 1855: 285

Type genus: Leucopholis Dejean, 1833: 160

\section{Subtribe Melolonthina Leach, 1819}

Original spelling and citation: Melolonthidæ Leach in Samouelle 1819: 189

Type genus: Melolontha Fabricius, 1775: 31

Synonym: Polyphyllina Burmeister, 1855

Original spelling and citation: Polyphyllidae Burmeister 1855: 397

Type genus: Polyphylla Harris, 1841: 30

Synonym: Tostegopterina LeConte, 1861

Original spelling and citation: Tostegopterae LeConte 1861: 139

Type genus: Tostegoptera Blanchard, 1851: 149

Synonym: Psilonychini Péringuey, 1904

Original spelling and citation: Psilonychides Péringuey, 1904: 184

Type genus: Psilonychus Burmeister, 1855: 288

\section{Tribe Pachydemini Burmeister, 1855}

Original spelling and citation: Pachydemidae Burmeister 1855: 437

Type genus: Pachydema Laporte, 1832: [1] (Laporte 1832b)

Remark: Calicnémites (Blanchard 1845: 219) was used for taxa within this tribe but this family-group name was not originally Latinized and has not been subsequently Latinized and accepted as valid, therefore it is unavailable. From the context of Blanchard (1845), all his "Famille" and "Groupe" names with the "ides" and "-ites" suffixes respectively are French vernacular names (some have accents).

Synonym: Elaphocerini Blanchard, 1851

Original spelling and citation: Elaphoceritae Blanchard 1851: 164

Type genus: Elaphocera Gené, 1836: 188

Remark: Although Elaphocerini has priority over Pachydemini, the later is in prevailing usage and must be considered the valid using a reversal of precedence (Article 23.9). Elaphocerini has not been used as a valid name after 1899. Therefore, I invoke Article 23.9.2 and provide evidence that Pachydemini has be used as a valid name in at least 25 works, published by at least 10 authors in the immediately preceding 50 years and encompassing a span of not less than 10 years. In compliance with the requirements of the Code, the following list of qualified publications, in chronological order, used Pachydemini as a valid family-group name, which is sufficient evidence that it is in prevailing usage: Petrovitz 1968; Martínez 1972; Martínez 1973; Frey 1974a; Frey 1974b; Martínez 1975; Hardy 1978; Baraud 1979; Baraud 1982; Martínez 1982; Baraud 1985; López Colón 1986; López Colón 1989; Baraud 1991; Baraud and Branco 1991; Chavanon and Zirari 1998; Sabatinelli and Pontuale 1998; Nikolajev 2000c; Lacroix 2001; Vincini, López, Alvarez-Castillo, Carmona, Manetti, and Morón 2001; Keith 2002; Miessen and Cludts 2002; Lacroix 2003; Montreuil 2003; Sanmartín 2003; Sanmartín and Martin-Piera 2003; Keith and Montreuil 2004; Lacroix 2004; Keith 2005; Lacroix 2005; Smith and Evans 2005.

Synonym: Achloini Burmeister, 1855

Original spelling and citation: Achloidae Burmeister 1855: 465

Type genus: Achloa Erichson, 1840: 41 
Synonym: Cephalotrichiini Burmeister, 1855

Original spelling and citation: Cephalotrichiadae Burmeister 1855: 433

Type genus: Cephalotrichia Hope, 1837: 39

Synonym: Leptopodini Burmeister, 1855

Original spelling and citation: Leptopodidae Burmeister 1855: 428

Type genus: Leptopus Dejean, 1833: 159

Remark: This family-group name is permanently invalid because the type genus, Leptopus Dejean, 1833, is a junior homonym of Leptopus Latreille, 1809 (Hemiptera), Leptopus Rafinesque, 1814 (Pisces), Leptopus Lamarck, 1818 (Crustacea), and Leptopus Fallén, 1823 (Diptera) (Article 39).

Synonym: Macrophyllini Burmeister, 1855

Original spelling and citation: Macrophyllidae Burmeister 1855: 447

Type genus: Macrophylla Hope, 1837: 103

Synonym: Sparrmanniini Péringuey, 1904

Original spelling and citation: Sparrmannini Péringuey 1904: 115

Type genus: Sparrmannia Laporte, 1840: 132

Remark: Although Sparmannia was the original spelling of this genus, Sparrmannia is in prevailing usage and should be considered the correct spelling (see Evans 1989).

Tribe Macrodactylini Kirby, 1837

Original spelling and citation: Macrodactylidae Kirby 1837: 133

Type genus: Macrodactylus Dejean, 1821: 58

Remark: Philochlénides (Lacordaire 1856: 256) was used for taxa within this tribe but was not originally Latinized and has not been subsequently Latinized and accepted as valid, therefore it is unavailable.

Synonym: Ceraspini Burmeister, 1855

Original spelling and citation: Ceraspididae Burmeister 1855: 91

Type genus: Ceraspis LePeletier and Serville, 1828: 370 (LePeletier and Serville, $1828 a)$

Synonym: Dichelonychini Burmeister, 1855

Original spelling and citation: Dichelonychidae Burmeister 1855: 70

Type genus: Dichelonyx Harris, 1827: 7

Synonym: Dicraniini Burmeister, 1855

Original spelling and citation: Dicraniadae Burmeister 1855: 65

Type genus: Dicrania LePeletier and Serville, 1828: 371 (LePeletier and Serville, $1828 a)$

Synonym: Isonychini Burmeister, 1855

Original spelling and citation: Isonychidae Burmeister 1855: 22

Type genus: Isonychus Mannerheim, 1829: 69

Synonym: Microcraniini Burmeister, 1855

Original spelling and citation: Microcraniadae Burmeister 1855: 75

Type genus: Microcrania Burmeister, 1855: 75

Synonym: Plectrini Burmeister, 1855

Original spelling and citation: Plectridae Burmeister 1855: 80

Type genus: Plectris LePeletier and Serville, 1828: 369 (LePeletier and Serville, $1828 a)$

Synonym: Clavipalpini Lacordaire, 1856

Original spelling and citation: Clavipalpides Lacordaire, 1856: 267

Type genus: Clavipalpus Laporte, 1832: 406 (Laporte 1832a) 
Remark: Clavipalpides (Lacordaire 1856: 267) and Clavipalpidae / Clavipalpides (Imhoff 1856: 12) were both used in the same year. The Imhoff (1856) paper refers to the Lacordaire (1856) paper numerous times. This is internal evidence in Imhoff (1856) that the Lacordaire (1856) paper was published first so Lacordaire should be credited with authorship of this family-group name. Although this family-group name was not originally proposed in a Latinized form it has subsequently been Latinized and should be considered available under Article 11.7.2.

Tribe DiphyCERINI Medvedev, 1952

Original spelling and citation: Diphycerini Medvedev 1952: 186

Type genus: Diphycerus Deyrolle and Fairmaire, 1878: 100

Tribe HopLIINI Latreille, 1829

Original spelling and citation: Hoplides Latreille 1829: 563

Type genus: Hoplia Illiger, 1803: 226

Subtribe Pachycnemina Laporte, 1840

Original spelling and citation: Pachycnémides Laporte 1840: 155

Type genus: Pachycnema LePeletier and Serville, 1828: 375 (LePeletier and Serville $1828 a$ )

Remark: Although this family-group name was not originally proposed in a Latinized form, it has subsequently been Latinized by numerous authors and should be considered available under Article 11.7.2.

Synonym: Anisonychina Burmeister, 1844

Original spelling and citation: Anisonychidae Burmeister 1844: 40

Type genus: Anisonyx Latreille, 1807: 119

\section{Subtribe Hoplina Latreille, 1829}

Original spelling and citation: Hoplides Latreille 1829: 563

Type genus: Hoplia Illiger, 1803: 226

Remark: Madahopliini Lacroix 1997: 21 was used but the family-group name was not based on an available genus-group name and is therefore unavailable. Madahoplia Lacroix, 1998: 551 was not described until the following year.

Synonym: Gymnolomina Burmeister, 1844

Original spelling and citation: Gymnolomidae Burmeister 1844: 138

Type genus: Gymnoloma Dejean, 1833: 167

Synonym: Heterochelina Burmeister, 1844

Original spelling and citation: Heterochelidae Burmeister 1844: 86

Type genus: Heterochelus Burmeister, 1844: 87

Synonym: Lepisiina Burmeister, 1844

Original spelling and citation: Lepisiidae Burmeister 1844: 166

Type genus: Lepisia LePeletier and Serville, 1828: 374 (LePeletier and Serville $1828 a)$

Synonym: Scelophysina Péringuey, 1902

Original spelling and citation: Scelophysides Péringuey, 1902: 624

Type genus: Scelophysa Burmeister, 1844: 168

Tribe Colymbomorphini Blanchard, 1850

Original spelling and citation: Colymbomorphitae Blanchard 1850: 97

Type genus: Colymbomorpha Blanchard, 1850: 98

\section{Tribe TANYPROCTINI Erichson 1847}

Original spelling and citation: Tanyproctini Erichson 1847b: 653

Type genus: Tanyproctus Ménétries, 1832: 185

\section{$\dagger$ Tribe Cretomelolonthini Nikolajev, 1998}

Original spelling and citation: Cretomelolonthini Nikolajev 1998: 80

Type genus: Cretomelolontha Nikolajev, 1998: 81 


\section{Subfamily Rutelinae MacLeay, 1819}

Original spelling and citation: Rutelidae MacLeay 1819: 69

Type genus: Rutela Latreille, 1802: 151

\section{Tribe Rutelini MacLeay, 1819}

Original spelling and citation: Rutelidae MacLeay 1819: 69

Type genus: Rutela Latreille, 1802: 151

\section{Subtribe Areodina Burmeister, 1844}

Original spelling and citation: Areodidae Burmeister 1844: 423

Type genus: Areoda MacLeay, 1819: 158

\section{Subtribe Heterosternina Bates, 1888}

Original spelling and citation: Heterosterninae Bates 1888: 286

Type genus: Heterosternus Dupont, 1832: 10

Synonym: Macropnina Horn, 1866

Original spelling and citation: Macropni Horn 1866: 398

Type genus: Macropnus Horn, 1866: 397

Remark: Although Macropnina has priority over Heterosternina, the later is in prevailing usage and must be considered the valid using a reversal of precedence (Article 23.9). Macropnina has not been used as a valid name since it was first proposed. Therefore, I invoke Article 23.9.2 and provide evidence that Heterosternina has be used as a valid name in at least 25 works, published by at least 10 authors in the immediately preceding 50 years and encompassing a span of not less than 10 years. In compliance with the requirements of the Code, the following list of qualified publications, in chronological order, used Hetero sternina as a valid family-group name, which is sufficient evidence that it is in prevailing usage: Machatschke 1972; Morón 1979; Morón 1983; Morón, Villalobos, and Deloya 1985; Morón 1987; Sigwalt 1987; Jameson 1990; Morón 1990; Morón 1991; Morón and Howden 1992; Morón 1993; Morón 1994; Delgado and Blackaller-Bages 1997; Morón 1997; Morón and Blackaller 1997; Jameson 1998; Morón, Deloya, Ramírez-Campos, and Hernández-Rodríguez 1998; Soula 1998; Delgado, Pérez, and Blackaller 2000; Morón and Nogueira 2000; Morón-Ríos and Morón 2001; Curoe and Morón 2003; Smith and Morón 2003; Paucar-Cabrera 2005; and Reyes Novelo and Morón 2005.

\section{Subtribe DidrePanePhorina Ohaus, 1918}

Original spelling and citation: Didrepanephorina Ohaus 1918: 14 Type genus: Didrepanephorus Wood-Mason, 1878: 423

\section{Subtribe Lasiocalina Ohaus, 1918}

Original spelling and citation: Lasiocalina Ohaus 1918: 30

Type genus: Lasiocala Blanchard, 1851: 220

\section{Subtribe Parastasinna Burmeister, 1844}

Original spelling and citation: Parastasiidae Burmeister 1844: 368

Type genus: Parastasia Westwood, 1841: 204 (Westwood 1841b)

\section{Subtribe ORyctomorphina Burmeister, 1847}

Original spelling and citation: Oryctomorphidae Burmeister 1847: 28

Type genus: Oryctomorphus Guérin-Méneville, 1831: 3

\section{Subtribe Desmonychina Arrow, 1917}

Original spelling and citation: Desmonychinæ Arrow 1917: 359

Type genus: Desmonyx Arrow, 1907: 355

\section{Subtribe Rutelina MacLeay, 1819}

Original spelling and citation: Rutelidae MacLeay 1819: 69

Type genus: Rutela Latreille, 1802: 151 
Synonym: Chasmodiina Burmeister, 1844

Original spelling and citation: Chasmodiidae Burmeister 1844: 333

Type genus: Chasmodia MacLeay, 1819: 155

Synonym: Chrysophorina Burmeister, 1844

Original spelling and citation: Chrysophoridae Burmeister 1844: 412

Type genus: Chrysophora Dejean, 1821: 60

Synonym: Macraspidina Burmeister, 1844

Original spelling and citation: Macraspididae Burmeister 1844: 343

Type genus: Macraspis MacLeay, 1819: 156

Synonym: Pelidnotina Burmeister, 1844

Original spelling and citation: Pelidnotidae Burmeister 1844: 388

Type genus: Pelidnota MacLeay, 1819: 157

Synonym: Anticheirina Lacordaire, 1856

Original spelling and citation: Antichirides Lacordaire 1856: 341

Type genus: Anticheira Eschscholtz, 1818: 475

Remark: Although this family-group name was not originally proposed in a Latinized form, it has subsequently been Latinized by numerous authors and should be considered available under Article 11.7.2.

Synonym: Plusiotina Bates, 1888

Original spelling and citation: Plusiotina Bates 1888: 276

Type genus: Plusiotis Burmeister, 1844: 417

Synonym: Fruhstorferiina Ohaus, 1918

Original spelling and citation: Frustorferiina Ohaus 1918: 43

Type genus: Fruhstorferia Kolbe, 1894

\section{Tribe Anatistini Imhoff, 1856}

Original spelling and citation: Anatistidae Imhoff, 1856: xi

Type genus: Anatista Brême, 1844: 305

Remark: Although Anatistini has not been used in any publication since before 1900 and Spodochlamyini has been used recently as a valid tribe, a reversal of precedence (Article 23.9) cannot be used to preserve the latter. Spodochlamyini has not been used as a valid name in at least 25 works published by at least 10 authors in the immediately preceding 50 years. Therefore, Anatistini must be considered the valid name for this tribe.

Synonym: Spodochlamyini Ohaus, 1918: 166

Original spelling and citation: Spodochlamyini Ohaus 1918: 166

Type genus: Spodochlamys Burmeister, 1855: 528

\section{Tribe Anoplognathini MacLeay, 1819}

Original spelling and citation: Anoplognathidae MacLeay 1819: 81

Type genus: Anoplognathus Leach, 1815: 156 (Leach 1815b)

\section{Subtribe Anoplognathina MacLeay, 1819}

Original spelling and citation: Anoplognathidae MacLeay 1819: 81

Type genus: Anoplognathus Leach, 1815: 156 (Leach 1815b)

\section{Subtribe Schizognathina Ohaus, 1918}

Original spelling and citation: Schizognathina Ohaus 1918: 174

Type genus: Schizognathus Fischer von Waldheim, 1823: 263

\section{Subtribe Phalangogonina Ohaus, 1918}

Original spelling and citation: Phalangogoniina Ohaus 1918: 176

Type genus: Phalangogonia Burmeister, 1844: 451 


\section{Subtribe Platycoelina Burmeister, 1844}

Original spelling and citation: Platycoeliidae Burmeister 1844: 451

Type genus: Platycoelia Dejean, 1833: 154

\section{Subtribe Brachysternina Burmeister, 1844}

Original spelling and citation: Brachysternidae Burmeister 1844: 455

Type genus: Brachysternus Guérin-Méneville, 1831: 3

\section{Tribe Geniatini Burmeister, 1844}

Original spelling and citation: Geniatidae Burmeister 1844: 478

Type genus: Geniates Kirby, 1819: 401 (Kirby 1819a)

Synonym: Leucothyreini Burmeister, 1844

Original spelling and citation: Leucothyreidae Burmeister 1844: 485

Type genus: Leucothyreus MacLeay, 1819: 145

\section{Tribe Alvarengini Frey, 1975}

Original spelling and citation: Alvarengiini Frey 1975: 84

Type genus: Alvarengius Frey, 1975: 84

Remark: Pachylides (Lacordaire 1856: 394) was used for taxa within this tribe but this family-group name was not originally Latinized and has not been subsequently Latinized and accepted as valid, therefore it is unavailable. Additionally, this name is based on the genus Pachylus Burmeister, 1847, which is a junior homonym.

Tribe Anomalini Streubel, 1839

Original spelling and citation: Anomalidae Streubel 1839: 136

Type genus: Anomala Samouelle, 1819: 191

Remark: The type genus, Anomala Samouelle, 1819, is not a junior homonym of Anomala von Block, 1799. The von Block name was suppressed for the purposes of the Principle of Priority and the Principle of Homonymy (ICZN 1989).

\section{Subtribe Anomalina Streubel, 1839}

Original spelling and citation: Anomalidae Streubel 1839: 136

Type genus: Anomala Samouelle, 1819: 191

Synonym: Euchlorina Hope, 1839

Original spelling and citation: Euchloridae Hope 1839: 67

Type genus: Euchlora MacLeay, 1819: 147

Remark: Although Euchlorina has priority over Anomalina, the later is in prevailing usage and must be considered the valid using a reversal of precedence (Article 23.9). Euchlorina has not been used as a valid name since it was first proposed. Therefore, I invoke Article 23.9.2 and provide evidence that Anomalina has be used as a valid name in at least 25 works, published by at least 10 authors in the immediately preceding 50 years and encompassing a span of not less than 10 years. In compliance with the requirements of the Code, the following list of qualified publications, in chronological order, used Anomalina (or this stem with any other family-group suffix) as a valid family-group name, which is sufficient evidence that it is in prevailing usage: Ritcher 1966; Howden and Hardy 1971; Machatschke 1971; Machatschke 1972; Machatschke 1973a; Machatschke 1973b; Woodruff 1973; Potts 1974; Potts 1977a; Potts 1977b; Jameson 1990; Ratcliffe 1991; Bader 1992; Cassis and Weir 1992; Morón 1997; Browne and Scholtz 1998; Jameson 1998; Harpootlian 2001; Micó, Verdú, and Galante 2001; Morón and Howden 2001; Ratcliffe, Jameson, and Smith 2002; Jameson, Paucar-Cabrera, and Solís 2003; Micó, Morón, and Galante 2003; Jameson and Hawkins 2005; Paucar-Cabrera 2005; Smith and Evans 2005; and Micó, Gómez, and Galante 2006.

Synonym: Dilophochilina Ohaus, 1918

Original spelling and citation: Dilophochilina Ohaus 1918: 133

Type genus: Dilophochila Bates, 1888: 261 
Subtribe PopIllina Ohaus, 1918

Original spelling and citation: Popilliina Ohaus 1918: 133

Type genus: Popillia Dejean, 1821: 60

Subtribe IsoplinNa Péringuey, 1902

Original spelling and citation: Isopliini Péringuey 1902: 564

Type genus: Isoplia Burmeister, 1855: 487

Subtribe AnISOPLIINA Burmeister, 1844

Original spelling and citation: Anisopliadae Burmeister 1844: 208

Type genus: Anisoplia Schönherr, 1817: 186

Subtribe Leptohoplina Potts, 1974

Original spelling and citation: Lepothopliini Potts 1974: 152

Type genus: Leptohoplia Saylor, 1935: 132

Remark: Potts (1974) inadvertently misspelled Leptohopliini when he erected the family-group name.

Tribe Adoretini Burmeister, 1844

Original spelling and citation: Adoretidae Burmeister 1844: 466

Type genus: Adoretus Laporte, 1840: 142

Subtribe Adorrhinyptinna Arrow, 1917

Original spelling and citation: Adorrhinyptiini Arrow 1917: 273

Type genus: Adorrinyptia Arrow, 1917: 273

\section{Subtribe Adoretina Burmeister, 1844}

Original spelling and citation: Adoretidae Burmeister 1844: 466

Type genus: Adoretus Laporte, 1840: 142

Synonym: Adorodociina Ohaus, 1912

Original spelling and citation: Adorodociina Ohaus 1912a: 151

Type genus: Adorodocia Brenske, 1893: 1

Synonym: Adoroleptina Ohaus, 1912

Original spelling and citation: Adoroleptina Ohaus 1912a: 151

Type genus: Adoroleptus Brenske, 1893: 1

Synonym: Pseudadoretina Ohaus, 1912

Original spelling and citation: Pseudadoretina Ohaus 1912a: 151

Type genus: Pseudadoretus Semenov-Tian-Shanskij, 1889: 202

Synonym: Scaphorhinadoretina Ohaus, 1912

Original spelling and citation: Scaphorhinadoretina Ohaus 1912a: 151

Type genus: Scaphorhinadoretus Ohaus, 1912: 426 (Ohaus 1912a)

Subtribe Pachyrhinadoretina Ohaus, 1912

Original spelling and citation: Pachyrhinadoretina Ohaus 1912a: 151

Type genus: Pachyrhinadoretus Ohaus, 1912: 509 (Ohaus 1912a)

Subtribe Trigonostomina Ohaus, 1912

Original spelling and citation: Trigonostomina Ohaus 1912a: 151

Type genus: Trigonostomum Burmeister, 1844: 466

Subtribe Prodoretina Ohaus, 1912

Original spelling and citation: Prodoretina Ohaus 1912a: 151

Type genus: Prodoretus Brenske, 1893: 1

\section{Subfamily Dynastinae MacLeay, 1819}

Original spelling and citation: Dynastidae MacLeay 1819: 64

Type genus: Dynastes MacLeay, 1819: 22 


\section{Tribe Hexodontin Lacordaire, 1856}

Original spelling and citation: Hexodontides Lacordaire 1856: 391

Type genus: Hexodon Olivier, 1789: 1

Remark: Lacordaire (1856: 391) and Imhoff (1856: 17) both used Hexodontides in the same year and the Imhoff (1856) paper refers to the Lacordaire (1856) paper (numerous times). This is internal evidence in Imhoff (1856) that the Lacordaire (1856) paper was published first so Lacordaire should be credited with authorship of this family-group name. Although this family-group name was not originally proposed in a Latinized form, it has subsequently been Latinized by numerous authors and should be considered available under Article 11.7.2.

\section{Tribe Cyclocephalini Laporte, 1840}

Original spelling and citation: Cyclocephalites Laporte 1840: 124

Type genus: Cyclocephala Dejean, 1821: 57

Remark: Although this family-group name was not originally proposed in a Latinized form, it has subsequently been Latinized by numerous authors and should be considered available under Article 11.7.2.

Synonym: Chalepini Burmeister, 1847

Original spelling and citation: Chalepidae Burmeister 1847: 71

Type genus: Chalepus MacLeay 1819: 149

Synonym: Peltonotini Arrow, 1917

Original spelling and citation: Peltonotini Arrow 1917: 27

Type genus: Peltonotus Burmeister, 1847: 75

Synonym: Acrobolbiini Ohaus, 1918

Original spelling and citation: Acrobolbiina Ohaus 1918: 13

Type genus: Acrobolbia Ohaus, 1912: 316 (Ohaus 1912b)

Tribe Dynastini MacLeay, 1819

Original spelling and citation: Dynastidae MacLeay 1819: 64

Type genus: Dynastes MacLeay, 1819: 22

Synonym: Xylotrupini Hope, 1845

Original spelling and citation: Xylotrupidae Hope 1845: 7

Type genus: Xylotrupes Hope, 1837: ix

Synonym: Megasomatidae Imhoff, 1856

Original spelling and citation: Megasomidae Imhoff 1856: 19

Type genus: Megasoma Kirby, 1825: 566

\section{Tribe Oryctini Mulsant, 1842}

Original spelling and citation: Oryctésaires Mulsant 1842: 372

Type genus: Oryctes Illiger, 1798: 11 (Kugelann and Illiger 1798)

Remark: Although this family-group name was not originally proposed in a Latinized form, it has subsequently been Latinized by numerous authors and should be considered available under Article 11.7.2.

Synonym: Megacerini Burmeister, 1847

Original spelling and citation: Megaceridae Burmeister 1847: 212

Type genus: Megaceras Hope, 1837: 82

Synonym: Strategini Burmeister, 1847

Original spelling and citation: Strategidae Burmeister 1847: 87

Type genus: Strategus Kirby, 1828: 644 (Kirby and Spence 1828)

\section{Tribe OryctoderinI Endrödi, 1966}

Original spelling and citation: Oryctoderini Endrödi 1966: 25

Type genus: Oryctoderus Boisduval, 1835: 160 


\section{Tribe Pentodontini Mulsant, 1842}

Original spelling and citation: Pentodonaires Mulsant 1842: 372

Type genus: Pentodon Hope, 1837: 30

Remark: Although this family-group name was not originally proposed in a Latinized form, it has subsequently been Latinized by numerous authors and should be considered available under Article 11.7.2.

\section{Subtribe Pentodontina Mulsant, 1842}

Original spelling and citation: Pentodonaires Mulsant 1842: 372

Type genus: Pentodon Hope, 1837: 30

Synonym: Bothynina Burmeister, 1847

Original spelling and citation: Bothynidae Burmeister 1847: 90

Type genus: Bothynus Hope, 1837: 30

Synonym: Pimelopodina Burmeister, 1847

Original spelling and citation: Pimelopodea Burmeister 1847: 172

Type genus: Pimelopus Erichson, 1842: 159

Synonym: Podalgina Burmeister, 1847

Original spelling and citation: Podalgidae Burmeister 1847: 90

Type genus: Podalgus Burmeister, 1847: 117

Synonym: Metanastina Carne, 1957

Original spelling and citation: Metanastini Carne 1957: 32

Type genus: Metanastes Arrow, 1911: 166 (Arrow 1911a)

Remark: When Carne (1957) erected this family-group name, he placed the genus Pentodon in it. Since Pentodon is the type genus of Pentodontina, Metanastini is unnecessary and should be considered a synonym of Pentodontina.

\section{Subtribe Cheiroplatina Carne, 1957}

Original spelling and citation: Cheiroplatina Carne 1957: 61

Type genus: Cheiroplatys Hope, 1837: 29

Subtribe Dipelicina Carne, 1957

Original spelling and citation: Dipelicina Carne 1957: 117

Type genus: Dipelicus Hope, 1843: 62

\section{Subtribe Pseudoryctina Carne, 1957}

Original spelling and citation: Pseudoryctina Carne 1957: 121

Type genus: Pseudoryctes Sharp, 1873: 267

\section{Tribe Agaocephalini Burmeister, 1847}

Original spelling and citation: Agaocephalidae Burmeister 1847: 280

Type genus: Agaocephala LePeletier and Serville, 1828: 570 (LePeletier and Serville, $1828 a)$

Remark: The original spelling of this genus is Agacephala, but it was later spelled Agaocephala by Mannerheim (1829: 56) and almost all authors since (although a few recent authors have used the original spelling). Since the incorrect subsequent spelling is in prevailing usage, it is now considered the correct original spelling of the name under Article 33.3.1.

\section{Tribe Phileurini Burmeister, 1847}

Original spelling and citation: Phileuridae Burmeister 1847: 138

Type genus: Phileurus Latreille, 1807: 103

\section{Subtribe Phileurina Burmeister, 1847}

Original spelling and citation: Phileuridae Burmeister 1847: 138

Type genus: Phileurus Latreille, 1807: 103 


\section{Subtribe Cryptodina Burmeister and Schaum, 1840}

Original spelling and citation: Cryptodinae Burmeister and Schaum 1840: 360 Type genus: Cryptodus MacLeay, 1819: 138

\section{Subfamily Cetoninae Leach, 1815}

Original spelling and citation: Cetonida Leach 1815a: 99

Type genus: Cetonia Fabricius, 1775: 42

Remark: Although Cetoniinae has priority over Melolonthinae, the later is in prevailing usage at the family level and must not be displaced by the older name under Article 35.5. This is relevant for authors who consider Melolonthidae to be a family containing the subfamily Cetoniinae.

\section{Tribe VALGinI Mulsant, 1842}

Original spelling and citation: Valguaires Mulsant 1842: 519

Type genus: Valgus Scriba, 1790: 66

Remark: Valguaires Mulsant (1842: 718) and Valgidae Burmeister (1842: 718) were both used in the same year. Mulsant (1842) was published in August 1842 (Sherborn 1922) and the introduction to Burmeister (1842) is dated September 1842. Therefore, Mulsant (1842) was published first and should be credited with authorship of this family-group name. Although this family-group name was not originally proposed in a Latinized form, it has subsequently been Latinized by numerous authors and should be considered available under Article 11.7.2.

\section{Subtribe Microvalgina Kolbe, 1904}

Original spelling and citation: Microvalginae Kolbe, 1904: 10

Type genus: Microvalgus Kraatz, 1883: 374

\section{Subtribe Valgina Mulsant, 1842}

Original spelling and citation: Valguaires Mulsant 1842: 519

Type genus: Valgus Scriba, 1790: 66

Synonym: Acanthovalgina Kolbe, 1904

Original spelling and citation: Acanthovalginae Kolbe 1904: 11

Type genus: Acanthovalgus Kraatz, 1895: 444

Synonym: Cosmovalgina Kolbe, 1904

Original spelling and citation: Cosmovalginae Kolbe 1904: 11

Type genus: Cosmovalgus Kolbe, 1897: 204

Synonym: Dasyvalgina Kolbe, 1904

Original spelling and citation: Dasyvalginae Kolbe 1904: 11

Type genus: Dasyvalgus Kolbe, 1904: 34

Synonym: Ischnovalgina Kolbe, 1904

Original spelling and citation: Ischnovalginae Kolbe 1904: 9

Type genus: Ischnovalgus Kolbe, 1897: 190

Synonym: Sphinctovalgina Kolbe, 1904

Original spelling and citation: Sphinctovalginae Kolbe 1904: 9

Type genus: Sphinctovalgus Kolbe, 1904: 51

\section{Tribe TrichIINI Fleming, 1821}

Original spelling and citation: Trichiadae Fleming 1821: 50

Type genus: Trichius Fabricius, 1775: 40

Remark: Trichiinae Lozek, 1956 (Mollusca: Gastropoda) is a junior homonym of this family-group name. A recent case to the International Commission on Zoological Nomenclature to emend the spelling of the gastropod to remove it from homonymy was not approved (ICZN 2004).

\section{Subtribe Cryptodontina Lacordaire, 1856}

Original spelling and citation: Cryptodontides Lacordaire 1856: 462

Type genus: Cryptodontes Burmeister, 1847: 292 
Remark: Although this family-group name was not originally proposed in a Latinized form, it has subsequently been Latinized by numerous authors and should be considered available under Article 11.7.2.

Subtribe Platygenina Krikken, 1984

Original spelling and citation: Platygeniini Krikken 1984: 18

Type genus: Platygenia MacLeay, 1819: 151

\section{Subtribe Trichinna Fleming, 1821}

Original spelling and citation: Trichiadae Fleming 1821: 50

Type genus: Trichius Fabricius, 1775: 40

Synonym: Elpidina Péringuey, 1907

Original spelling and citation: Elpidides Péringuey, 1907: 314

Type genus: Elpidus Péringuey, 1907: 318

Synonym: Myodermina Péringuey, 1907

Original spelling and citation: Myodermini Péringuey 1907: 294

Type genus: Myodermum Burmeister and Schaum, 1840: 396

\section{Subtribe InCaIna Burmeister, 1842}

Original spelling and citation: Incadae Burmeister 1842: 704

Type genus: Inca LePeletier and Serville, 1828: 380 (LePeletier and Serville, 1828a)

\section{Subtribe Osmodermatina Schenkling, 1922}

Original spelling and citation: Osmodermini Schenkling 1922: 3

Type genus: Osmoderma LePeletier and Serville, 1828: 702 (LePeletier and Serville, 1828b)

Tribe Cremastocheilini Burmeister and Schaum, 1841

Original spelling and citation: Cremastochilidae Burmeister and Schaum 1841: 243

Type genus: Cremastocheilus Knoch, 1801: 115

Subtribe SPILOPHORINa Krikken, 1984

Original spelling and citation: Spilophorina Krikken 1984: 25

Type genus: Spilophorus Schaum, 1848: 61*

\section{Subtribe Macromina Burmeister and Schaum, 1840}

Original spelling and citation: Macrominae Burmeister and Schaum 1840: 360 Type genus: Macroma Gory and Percheron, 1833: 35

\section{Subtribe Trogodina Krikken, 1984}

Original spelling and citation: Trogodina Krikken 1984: 27

Type genus: Trogodes Westwood, 1874: 30

\section{Subtribe Nyassinina Krikken, 1984}

Original spelling and citation: Nyassinina Krikken 1984: 25

Type genus: Nyassinus Westwood, 1879: 199

\section{Subtribe Heterogenina Krikken, 1984}

Original spelling and citation: Heterogeniina Krikken 1984: 25

Type genus: Heterogenius Moser, 1911: 143

\section{Subtribe AsPILINA Krikken, 1984}

Original spelling and citation: Aspilina Krikken 1984: 25

Type genus: Aspilus Schaum, 1848: 61*

\section{Subtribe Coenochilina Burmeister, 1842}

Original spelling and citation: Coenochilidae Burmeister 1842: 148

Type genus: Coenochilus Schaum, 1841: 268 (in Burmeister and Schaum 1841) 
Subtribe Cymophorina Krikken, 1984

Original spelling and citation: Cymophorina Krikken 1984: 23

Type genus: Cymophorus Kirby, 1827: 153

Subtribe Trichoplina Krikken, 1984

Original spelling and citation: Trichoplina Krikken 1984: 23

Type genus: Trichoplus Burmeister, 1842: 660

Subtribe Oplostomatina Krikken, 1984

Original spelling and citation: Oplostomina Krikken 1984: 23

Type genus: Oplostomus MacLeay, 1838: 20

Subtribe Telochilina Krikken, 1984

Original spelling and citation: Telochilina Krikken 1984: 21

Type genus: Telochilus Krikken, 1975: 21

Subtribe Genuchina Krikken, 1984

Original spelling and citation: Genuchina Krikken 1984: 21

Type genus: Genuchus Kirby, 1825: 569

Subtribe Pilinurgina Krikken, 1984

Original spelling and citation: Pilinurgina Krikken 1984: 25

Type genus: Pilinurgus Burmeister, 1842: 658

Subtribe Goliathopsidina Krikken, 1984

Original spelling and citation: Goliathopsidina Krikken 1984: 25

Type genus: Goliathopsis Janson, 1881: 609

Subtribe Cremastocheiluna Burmeister and Schaum, 1841

Original spelling and citation: Cremastochilidae Burmeister and Schaum 1841: 243 Type genus: Cremastocheilus Knoch, 1801: 115

\section{Subtribe LissogenIINa Krikken, 1984}

Original spelling and citation: Lissogeniina Krikken 1984: 25

Type genus: Lissogenius Schaum, 1845: 420

Tribe XIPHOSCELIDINI Burmeister, 1842

Original spelling and citation: Xiphoscelideae Burmeister 1842: 613

Type genus: Xiphoscelis Burmeister, 1842: 613

\section{Tribe Stenotarsinn Kraatz, 1880}

Original spelling and citation: Stenotarsiden Kraatz 1880b: 182

Type genus: Stenotarsia Burmeister, 1842: 590

Remark: Although this family-group name was not originally proposed in a Latinized form, it has subsequently been Latinized by numerous authors and should be considered available under Article 11.7.2.

\section{Subtribe CoptomiIna Schenkling, 1921}

Original spelling and citation: Coptomiini Schenkling 1921: 147

Type genus: Coptomia Burmeister, 1842: 549

\section{Subtribe AnochILIINa Krikken, 1984}

Original spelling and citation: Anochiliina Krikken 1984: 31

Type genus: Anochilia Burmeister, 1842: 558

Remark: Pouillaude (1916) used Anochiliens but this name was published after 1900 and not Latinized, therefore it is unavailable from this publication.

\section{Subtribe Pantolina Krikken, 1984}

Original spelling and citation: Pantoliina Krikken 1984: 33

Type genus: Pantolia Burmeister, 1842: 567

Remark: Pouillaude (1916) used Pantoliens but this name was published after 1900 and not Latinized, therefore it is unavailable from this publication. 


\section{Subtribe Stenotarsina Kraatz, 1880}

Original spelling and citation: Stenotarsiden Kraatz 1880b: 182

Type genus: Stenotarsia Burmeister, 1842: 590

Remark: Although this family-group name was not originally proposed in a Latinized form, it has subsequently been Latinized by numerous authors and should be considered available under Article 11.7.2.

Subtribe Euchroeina Paulian and Descarpentries, 1982

Original spelling and citation: Euchroeina Paulian and Descarpentries 1982: 5 Type genus: Euchroea Burmeister, 1842: 571

Remark: Pouillaude (1916) used Euchrœens but this name was published after 1900 and not Latinized, therefore it is unavailable from this publication.

Subtribe Doryscelina Krikken, 1984

Original spelling and citation: Doryscelina Krikken 1984: 33

Type genus: Doryscelis Dejean, 1836: 189

Remark: Pouillaude (1916) used Dorysceliens but this name was published after 1900 and not Latinized, therefore it is unavailable from this publication.

Subtribe Parachilina Krikken, 1984

Original spelling and citation: Parachiliina Krikken 1984: 33

Type genus: Parachilia Burmeister, 1842: 556

\section{Subtribe Heterophanina Schoch, 1894}

Original spelling and citation: Heterophanae Schoch 1894: 173

Type genus: Heterophana Burmeister, 1842: 602

\section{Subtribe ChromoptiLIna Krikken, 1984}

Original spelling and citation: Chromoptiliina Krikken 1984: 31

Type genus: Chromoptilia Westwood, 1842: 128 (Westwood 1842d)

\section{Subtribe Heterosomatina Krikken, 1984}

Original spelling and citation: Heterosomatina Krikken 1984: 29

Type genus: Heterosoma Schaum, 1845: 390

\section{Tribe SchizorhinINI Burmeister, 1842}

Original spelling and citation: Schizorrhinidae Burmeister 1842: 530

Type genus: Schizorhina Kirby, 1825: 570

\section{Subtribe Schizorhinina Burmeister, 1842}

Original spelling and citation: Schizorrhinidae Burmeister 1842: 530

Type genus: Schizorhina Kirby, 1825: 570

Synonym: Diaphoniina Kraatz, 1880

Original spelling and citation: Diaphoniadae Kraatz 1880b: 195

Type genus: Diaphonia Newman, 1840: 366

Synonym: Eupoecilina Kraatz, 1880

Original spelling and citation: Eupoecilidae Kraatz 1880b: 188

Type genus: Eupoecila Burmeister, 1842: 540

Synonym: Hemipharina Kraatz, 1880

Original spelling and citation: Hemipharidae Kraatz 1880b: 182

Type genus: Hemipharis Burmeister, 1842: 531

\section{Subtribe LoMAPTERINa Burmeister, 1842}

Original spelling and citation: Lomapteridae Burmeister 1842: 310

Type genus: Lomaptera Gory and Percheron, 1833: 43

Synonym: Macronotina Burmeister, 1842

Original spelling and citation: Macronotidae Burmeister 1842: 318

Type genus: Macronota Hoffmannsegg, 1817: 15 


\section{Tribe Goliathini Griffith and Pidgeon, 1832}

Original spelling and citation: Goliathidae Griffith and Pidgeon 1832: 492

Type genus: Goliathus Lamarck, 1801: 209

\section{Subtribe Goliathina Griffith and Pidgeon, 1832}

Original spelling and citation: Goliathidae Griffith and Pidgeon 1832: 492

Type genus: Goliathus Lamarck, 1801: 209

Synonym: Hypselogeniina Schoch, 1894

Original spelling and citation: Hypselogeniae Schoch 1894: 169

Type genus: Hypselogenia Burmeister, 1840: [1]

\section{Subtribe Dicronocephalina Krikken, 1984}

Original spelling and citation: Dicronocephalina Krikken 1984: 37

Type genus: Dicronocephalus Hope, 1831: 24

Remark: The original spelling of this genus is Dicranocephalus, but it was later spelled Dicronocephalus by Hope (1837: 61), Westwood (1842c: 116), and most authors since (although a few recent authors have used the original spelling). Since the incorrect subsequent spelling is in prevailing usage, it is now considered the correct original spelling of the name under Article 33.3.1. The original spelling placed the name in homonymy with Dicranocephalus Hahn, 1826 (Hemiptera) but the adaptation of the subsequent spelling as the correct spelling avoids this homonymy problem.

\section{Subtribe ICHNESTOMATINA Burmeister, 1842}

Original spelling and citation: Ischnostomidae Burmeister 1842: 600

Type genus: Ichnestoma Gory and Percheron, 1833: 41

\section{Subtribe CoRYPHOCERINa Burmeister, 1842}

Original spelling and citation: Coryphoceridae Burmeister 1842: 215

Type genus: Coryphocera Burmeister, 1842: 220

Synonym: Heterorhinina Kraatz, 1880

Original spelling and citation: Heterorrhinidae Kraatz 1880a: 21

Type genus: Heterorhina Westwood, 1842: 132 (Westwood 1842e)

Remark: Wallace (1868: 520) used "Heterorhinae" but from the context of the paper, it is clearly a lapsus calami for the genus Heterorhina. He did not intend to erect a new family-group name.

Synonym: Ceratorhinina Kraatz, 1880

Original spelling and citation: Ceratorrhinidae Kraatz 1880a: 18

Type genus: Ceratorhina Westwood, 1843: 170

Synonym: Bothrorrhinina Schoch, 1894

Original spelling and citation: Bothrorrhinae Schoch 1894: 173

Type genus: Bothrorrhina Burmeister, 1842: 200

Synonym: Gnathocerina Schoch, 1894

Original spelling and citation: Gnathoceridae Schoch 1894: 170

Type genus: Gnathocera Kirby, 1825: 571

Synonym: Ischnoscelina Schoch, 1894

Original spelling and citation: Ischnosceli Schoch 1894: 170

Type genus: Ischnoscelis Burmeister, 1842: 179

Synonym: Coelorrhinina Schoch, 1895

Original spelling and citation: Coelorrhinae Schoch 1895: III

Type genus: Coelorrhina Hope, 1841: 302

Remark: The original spelling of this genus is Caelorrhina, but it was later spelled Coelorrhina by Burmeister (1842: 206) and most authors since. Because the incorrect subsequent spelling is in prevailing usage, it is now considered the correct original spelling of the name under Article 33.3.1. 
Synonym: Rhomborhinina Schoch, 1894

Original spelling and citation: Rhomborrhinae Schoch 1894: 171

Type genus: Rhomborhina Hope, 1837: 120

Synonym: Tmesorrhinina Schoch, 1894

Original spelling and citation: Tmesorrhinae Schoch 1894: 170

Type genus: Tmesorrhina Westwood, 1842: 71 (Westwood 1842b)

Synonym: Mecynorhinina Schenkling, 1921

Original spelling and citation: Mecynorrhinina Schenkling 1921: 15

Type genus: Mecynorhina Hope, 1837: 119

Synonym: Stephanorrhinina Schenkling, 1921

Original spelling and citation: Stephanorrhinina Schenkling 1921: 35

Type genus: Stephanorrhina Burmeister, 1842: 208

\section{Tribe Cetoninn Leach, 1815}

Original spelling and citation: Cetonida Leach 1815a: 99

Type genus: Cetonia Fabricius, 1775: 42

\section{Subtribe Cetonina Leach, 1815}

Original spelling and citation: Cetonida Leach 1815a: 99

Type genus: Cetonia Fabricius, 1775: 42

Synonym: Elaphinina Schoch, 1894

Original spelling and citation: Elaphinina Schoch 1894: 175

Type genus: Elaphinis Burmeister, 1842: 595

Synonym: Glycyphanina Schoch, 1894

Original spelling and citation: Glycyphanina Schoch 1894: 175

Type genus: Glycyphana Burmeister, 1842: 345

Synonym: Pachnodina Péringuey, 1907

Original spelling and citation: Pachnodii Péringuey 1907: 371

Type genus: Pachnoda Burmeister, 1842: 511

Synonym: Tephraeina Schenkling, 1921

Original spelling and citation: Tephraeides Schenkling, 1921: 313

Type genus: Tephraea Burmeister, 1842: 419

\section{Subtribe Euphorina Schoch, 1894}

Original spelling and citation: Euphoriae Schoch 1894: 175

Type genus: Euphoria Burmeister, 1842: 370

\section{Subtribe Leucocelina Kraatz, 1882}

Original spelling and citation: Leucoceliden Kraatz 1882b: 65

Type genus: Leucocelis Burmeister, 1842: 421

Remark: Although this family-group name was not originally proposed in a Latinized form, it has subsequently been Latinized by numerous authors and should be considered available under Article 11.7.2.

\section{Tribe Gymnetini Kirby, 1827}

Original spelling and citation: Gymnetidae Kirby 1827: 150

Type genus: Gymnetis MacLeay, 1819: 152

\section{Subtribe Gymnetina Kirby, 1827}

Original spelling and citation: Gymnetidae Kirby 1827: 150

Type genus: Gymnetis MacLeay, 1819: 152

Synonym: Clinteriina Kraatz, 1882

Original spelling and citation: Clinteriidae Kraatz 1882a: 49

Type genus: Clinteria Burmeister, 1842: 299 
Synonym: Stethodesmatina Schoch, 1894

Original spelling and citation: Stethodesmae Schoch 1894: 172

Type genus: Stethodesma Bainbridge, 1841: 482

\section{Subtribe BLAEsIINA Schoch, 1895}

Original spelling and citation: Blaesiina Schoch, 1895: III

Type genus: Blaesia Burmeister, 1842: 615

\section{Tribe Diplognathini Burmeister, 1842}

Original spelling and citation: Diplognathidae Burmeister 1842: 617

Type genus: Diplognatha Gory and Percheron, 1833: 31

Remark: The type genus was spelled both Diplognatha and Diplognata in Gory and Percheron (1833). The former spelling was used multiple times and is obviously the intended spelling of the name. Diplognatha has also been adapted by all subsequent authors and should be considered the correct spelling.

Synonym: Porphyronotini Péringuey, 1907

Original spelling and citation: Porphyronotii Péringuey 1907: 371

Type genus: Porphyronota Burmeister, 1842: 622

\section{Tribe Phaedimini Schoch, 1894}

Original spelling and citation: Phaedimi Schoch 1894: 169

Type genus: Phaedimus Westwood, 1841: 5 (Westwood 1841a)

Tribe Taenioderini Mikšić, 1976

Original spelling and citation: Taenioderina Mikšić 1976: 29

Type genus: Taeniodera Burmeister, 1842: 325

\section{Subtribe TaEnIODERINa Mikšić, 1976}

Original spelling and citation: Taenioderina Mikšić 1976: 29

Type genus: Taeniodera Burmeister, 1842: 325

\section{Subtribe Chalcotheina Mikšić, 1976}

Original spelling and citation: Chalcotheina Mikšić 1976: 29

Type genus: Chalcothea Burmeister, 1842: 319

\section{Acknowledgments}

I thank Luca Bartolozzi (Museo di Storia Naturale dell'Università di Firenze), Aleš Bezděk (Institute of Entomology, Academy of Sciences of the Czech Republic), Art Evans (Virginia Museum of Natural History), Phil Harpootlian (Simpsonville, South Carolina), Dave Hawks (University of California-Riverside), Mary Liz Jameson (University of Nebraska), Frank Krell (The Natural History Museum, London), Al Newton (Field Museum of Natural History, Chicago), Matt Paulsen (University of Nebraska), Brett Ratcliffe (University of Nebraska), and Fernando Vaz-de-Mello (Instituto de Ecología, Xalapa, Mexico) for critical reviews, nomenclatural advice, and / or taxonomic insights into various scarabs groups. My acknowledgment of those listed above does not necessarily indicate that they agree with the classification or nomenclatural decisions within. I greatly appreciate assistance by the following people in finding old and obscure literature: Aleš Bezděk ((Institute of Entomology, Academy of Sciences of the Czech Republic), Pat Bouchard (Canadian National Collection of Insects), François Génier (Canadian Museum of Nature), Henry Howden (Canadian Museum of Nature), Frank Krell (The Natural History Museum, London), Al Newton (Field Museum of Natural History, Chicago), Matt Paulsen (University of Nebraska), Brett Ratcliffe (University of Nebraska), Paul Robbins (Cornell University), Aleš Smetana (Canadian National Collection of Insects), Fernando Vaz-deMello (Instituto de Ecología, Xalapa, Mexico), Mike Wayne (Canadian Museum of Nature Library), and Jason Weintraub (Academy of Natural Sciences, Philadelphia). I would also like to thank Neal Evenhuis (Bishop Museum, Honolulu) for graciously answering my numerous, pesky questions about the publication dates of old and / or obscure literature. This publication was supported, in part, by an NSF/BS\&I grant (DEB-0342189) to A. B. T. 
Smith and F. C. Ocampo, an NSF/PEET grant (DEB-0118669) to M. L. Jameson and B. C. Ratcliffe, and an NSERC-PDF award to A. B. T. Smith.

\section{References Cited}

Ádám, L. 2003. Faunisztikai adatok a Kárpát-medencéböl (Coleoptera: Scarabaeoidea). Folia Historico Naturalia Musei Matraensis 27:101-136.

Agassiz, L. 1847. Nomenclatoris Zoologici Index Universalis, Continens Nomina Systematica Classium, Ordinum, Familiarum et Generum Animalium Omnium, Tam Viventium quam Fossilium, Secundum Ordinem Alphabeticum Unicum Disposita, Adjectis Homonymiis Plantarum, nec non Variis Adnotationibus et Emendationibus. Nomenclator Zoologicus, volume 12. Jent et Gassmann, Solothurn. [Dated 1846.]

Allsopp, P. G. 1981. Revision of the Australian species of Phaenognatha Hope (Coleoptera: Scarabaeidae: Aclopinae). Journal of the Australian Entomological Society 20:185-195.

Alonso-Zarazaga, M. A., and C. H. C. Lyal. 1999. A World Catalogue of Families and Genera of Curculionoidea (Insecta: Coleoptera) (Excepting Scolytidae and Platypodidae). Entomopraxis, Barcelona.

Arrow, G. J. 1904. Sound-production in the Lamellicorn beetles. Transactions of the Entomological Society of London 52:709-750.

Arrow, G. J. 1905. On some oriental aphodiid Coleoptera of the Rhyparus group, with description of a new genus. Annals and Magazine of Natural History (series 7) 15:534-540.

Arrow, G. J. 1907. Some new species and genera of Lamellicorn Coleoptera from the Indian Empire. Annals and Magazine of Natural History (series 7) 19:347-359.

Arrow, G. J. 1911a. Notes on the coleopterous subfamily Dynastinae, with descriptions of new genera and species. Annals and Magazine of Natural History (series 8) 8:151-176, plates 4-5.

Arrow, G. J. 1911b. Upon the Dynamopinae, a new subfamily of Lamellicorn beetle. Annals and Magazine of Natural History (series 8) 8:610-612.

Arrow, G. J. 1917. The Fauna of British India, Including Ceylon and Burma. Coleoptera Lamellicornia Part II (Rutelinae, Desmonycinae, and Euchirinae). Taylor and Francis, London, U.K.

Arrow, G. J. 1931. The Fauna of British India, Including Ceylon and Burma. Coleoptera Lamellicornia Part III (Coprinae). Taylor and Francis, London.

Arrow, G. J. 1940. A nomenclatural note (Coleoptera). Proceedings of the Royal Entomological Society of London. Series B. Taxonomy 9:16.

Arrow, G. J. 1950. The Fauna of India including Pakistan, Ceylon, Burma and Malaya. Coleoptera Lamellicornia; Lucanidae and Passalidae, volume 4. Taylor and Francis, London.

Audouin, M. V., and M. A. Brullé. 1837. Histoire Naturelle des Insectes, volume 6. Coléoptères 3. F. D. Pillot, Paris, France.

Bader, A. M. 1992. A review of the North and Central American Strigoderma (Coleoptera: Scarabaeidae). Transactions of the American Entomological Society 118:269-355.

Bainbridge, W. 1841. Descriptions of new species of Cetoniadae in the collection of the Rev. F. W. Hope, with some observations on the genus Osmoderma. Annals and Magazine of Natural History series 1 volume 6:481-482.

Balthasar, V. 1964. Monographie der Scarabaeidae und Aphodiidae der palaearktischen und orientalischen Region. Coleoptera: Lamellicornia. Band 3. Tschechoslowakischen Akademie der Wissenschaften, Prague, Czechoslovakia.

Baraud, J. 1979. Coléoptères Scarabaeoidea de l'Afrique du Nord, 3 e note: les Pachydemini. Annales de la Société Entomologique de France (N. S.) 15:247-310.

Baraud, J. 1982. Nouveaux Pachydemini et Onthophagini de la faune paléarctique. Nouvelle Revue d'Entomologie 12:235-240.

Baraud, J. 1985. Révision des Pachydemini des îles Canaries (Coleoptera, Melolonthidae). Nouvelle Revue d'Entomologie (N. S.) 2:129-140. 
Baraud, J. 1991. Otoclinius loebli, nouvelle espéce d'Iran (Coleoptera, Melolonthidae, Pachydeminae). Archives des Sciences 44:289-291.

Baraud, J., and T. Branco. 1991. Scission du genre Pachydemocera Reitter, 1902 (Coleoptera, Melolonthidae, Pachydeminae). Bulletin de la Société Entomologique de France 96:175-181.

Basilewsky, P. 1952. Un Lucanide nouveau du Ruanda. Revue de Zoologie et de Botanique Africaines 46:35-40.

Bates, H. W. 1888. Insecta. Coleoptera. Rutelidae [pp. 216-296]. In: Biologia CentraliAmericana, volume 2, part 2. F. D. Godman and O. Salvin (eds.).

Benderitter, E. 1920. Description d'un genre et de deux espèces nouvelles d'Ochodaeinae. Annales de la Société Entomologique de Belgique 60:112-113.

Benesh, B. 1955a. Some notes on Neotropical stagbeetles (Coleoptera: Lucanidae). Entomological News 66:97-104.

Benesh, B. 1955b. Some further notes on the stagbeetles, with especial reference to Figulinae (Coleoptera: Lucanidae). Transactions of the American Entomological Society 81:59-76.

Benesh, B. 1960. Familia Lucanidae. Coleopterorum Catalogus Supplementa 8:1-178.

Berthold, A. A. 1827. Latreille's Natürliche Familien des Thierreichs. Aus dem Französischen. Mit Anmerkungen und Zusätzen. Landes-Industrie-Comptoir, Weimar.

Billberg, G. J. 1820. Novae insectorum species descriptiae. Mémoires de l'Académie Impérialedes Sciences de St. Pétersbourg (5)7:381-395.

Blackburn, T. 1898. Further notes on Australian Coleoptera, with descriptions of new genera and species. XXIII. Transactions of the Royal Society of South Australia 22:18-64.

Blanchard, C. É. 1845. Histoire des Insectes, Traitant de leurs Mours et de leurs Métamorphoses en Général et Comprenant une Nouvelle Classification Fondée sur leurs Rapports Naturels. Hyménoptères et Coléoptères, part 1. Firmin Didot Frères, Paris, France.

Blanchard, C. É. 1850. Ordre des Coleoptera. In: Muséum d'Histoire Naturelle de Paris. Catalogue de la Collection Entomologique. Classe des Insectes. vol. 1, part 1. H. MilneEdwards, C. É. Blanchard, and H. Lucus (eds.). Gide and Baudry, Paris, France.

Blanchard, C. É. 1851. Ordre des Coleoptera. In: Muséum d'Histoire Naturelle de Paris. Catalogue de la Collection Entomologique. Classe des Insectes. vol. 1, part 2. H. MilneEdwards, C. É. Blanchard, and H. Lucus (eds.). Gide and Baudry, Paris, France.

Boisduval, J. B. A. 1835. Voyage de Découvertes de L'Astrolabe Exécuté par Ordre du Roi, Pendant les Années 1826-1827-1828-1829, nous le Commandement de M. J. Dumont D'Urville. Fauna Entomologique de l'Océan Pacifique, avec l'Illustration des Insectes Nouveaux Recueillis Pendant le Voyage. Deuxiéme Partie. Coléoptéres et Autres Ordres. J. Tastu, Paris, France.

Bouchard, P., J. F. Lawrence, A. Davies, and A. F. Newton. 2005. Synoptic classification of the world Tenebrionidae (Insecta: Coleoptera) with a review of family-group names. Annales Zoologici 55:499-530.

Boucher, S. 2005. Évolution et phylogénie des Coléoptères Passalidae (Scarabaeoidea). Annales de la Société Entomologique de France 41:239-604.

Boucomont, A. 1909. Notes sur quelques sous-genres de Bolboceras [Col.] et description d'un sous-genre nouveau. Bulletin de la Société entomologique de France 1909:116-118.

Boucomont, A. 1911. Contribution a la classification de Geotrypidae [Col.]. Annales de la Société Entomologique de France 79:333-350. [Dated 1910].

Boucomont, A. 1923. Coprophaga Africana 2me note. Revue Zoologique Africaine 11:1-19.

Boucomont, A. 1932. Genre nouveau et espèces nouvelles ou peu connues de Bolbocerinia [Col. Scarabaeidae]. Bulletin de la Société Entomologique de France 37:262-268.

Bovo, B., and M. Zunino. 1983. Nuovi generi di Geotrupini (Coleoptera, Scarabaeoidea: Geotrupidae) asiatici. Bollettino del Museo Regionale di Scienze Naturali Torino $1: 397-416$.

Branco, T. 2006. Authorship and date of the genus-group names Rhizotrogus and Amphimallon (Coleoptera: Melolonthidae). Elytron 19:43-48. [Dated 2005.]. 
Brême, F. 1844. Insectes Coléoptères nouveaux ou peu connus. Première et deuxième decades. Annales de la Société Entomologique de France 2:287-313.

Brenske, E. 1893. Zur Kenntniss der Adoretiden Madagascars. Societas Entomologica $8: 1-2$.

Brenske, E. 1898. Die Serica-Arten der Erde. Monographisch bearbeitet. Berliner Entomologische Zeitschrift 42:345-438. [Dated 1897].

Britton, E. B. 1955. Coleoptera: Scarabaeidae: Melolonthinae and Dynastinae from the Monte Bello Islands, 1952. Proceedings of the Linnean Society of London 165:124-126.

Britton, E. B. 1957. A Revision of the Australian Chafers (Coleoptera: Scarabaeidae: Melolonthinae). Volume 1. British Museum (Natural History), London, U.K.

Britton, E. B. 1978. A revision of the Australian chafers (Coleoptera: Scarabaeidae: Melolonthinae) vol. 2. Tribe Melolonthini. Australian Journal of Zoology Supplementary Series 60:1-150.

Britton, E. B. 1986. A revision of the Australian chafers (Coleoptera: Scarabaeidae: Melolonthinae) Vol. 4. Tribe Liparetrini: genus Colpochila. Australian Journal of Zoology Supplementary Series 118:1-135.

Broun, T. 1886. Manual of New Zealand Coleoptera, parts 3 and 4. George Didsbury, Government Printer, Wellington, New Zealand.

Browne, D. J., and C. H. Scholtz. 1995. Phylogeny of the families of Scarabaeoidea (Coleoptera) based on characters of the hindwing articulation, hindwing base and wing venation. Systematic Entomology 20:145-173.

Browne, J., and C. H. Scholtz. 1998. Evolution of the scarab hindwing articulation and wing base: a contribution toward the phylogeny of the Scarabaeidae (Scarabaeoidea: Coleoptera). Systematic Entomology 23:307-326.

Burmeister, H. 1840. III. Coleoptera. 7. Lamellicornia. 40. Hypselogenia, 2 unnumbered pages. In: Genera Quaedam Insectorum. H. Burmeister (ed.). Privately published, Berlin, Germany.

Burmeister, H. 1842. Handbuch der Entomologie, volume 3. T.C.F. Enslin, Berlin, Germany.

Burmeister, H. 1844. Handbuch der Entomologie, volume 4, part 1. T.C.F. Enslin, Berlin, Germany.

Burmeister, H. 1846. III. Coleoptera. 7. Lamellicornia. 27. Copris, 4 unnumbered pages. In: Genera Quaedam Insectorum. H. Burmeister (ed.). Privately published, Berlin, Germany.

Burmeister, H. 1847. Handbuch der Entomologie, volume 5. T.C.F. Enslin, Berlin, Germany.

Burmeister, H. 1855. Handbuch der Entomologie, volume 4, part 2. T.C.F. Enslin, Berlin, Germany.

Burmeister, H. 1873. Lamellicornia Argentina. Stettiner Entomologische Zeitung 34:403-417.

Burmeister, H., and H. Schaum. 1840. Kritische Revision der Lamellicornia melitophila. Zeitschrift für die Entomologie 2:353-378.

Burmeister, H., and H. Schaum. 1841. Kritische Revision der Lamellicornia melitophila. Zeitschrift für die Entomologie 3:226-282.

Cambefort, Y. 1991. From saprophagy to coprophagy [pp. 22-35]. In: Dung Beetle Ecology. I. Hanski and Y. Cambefort (eds.). Princeton University Press, Princeton, NJ.

Carlson, D. V., and P. O. Ritcher. 1974. A new genus of Ochodaeinae and a description of the larva of Pseudochodaeus estriatus (Schaeffer) (Coleoptera: Scarabaeidae). PanPacific Entomologist 50:99-110.

Carne, P. B. 1957. A Systematic Revision of the Australian Dynastinae (Coleoptera: Scarabaeidae). Commonwealth Scientific and Industrial Research Organization, Melbourne, Australia.

Cartwright, O. L. 1977. A new species of Psammodius from sand dunes of California (Scarabaeidae: Aphodiinae: Eupariina). Coleopterists Bulletin 31:281-282.

Cassis, G., and T. A. Weir. 1992. Rutelinae [pp. 359-382]. In: Zoological Catalogue of Australia. Coleoptera: Scarabaeoidea, volume 9. W. W. K. Houston and T. A. Weir (eds.). AGPS, Canberra, Australia. 
Chalumeau, F. 1983. Batesiana et Martinezia, nouveaux genres d'Eupariini (Coleoptera: Scarabaeidae: Aphodiinae) du nouveau monde. Bulletin Mensuel de la Société Linnéenne de Lyon 52:142-153.

Chalumeau, F. 1992. Eupariini du nouveau monde: un mise au point (Coleoptera, Scarabaeidae) (1 re partie). Nouvelle Revue d'Entomologie 9:189-206.

Chavanon, G., and A. Zirari. 1998. Un nouveau Pachydema Castelnau, 1832 du Maroc: Pachydema camberforti n. sp. (Coleoptera, Melolonthidae). Nouvelle Revue d'Entomologie (N. S.) 15:329-331.

*Creutzer, C. 1799. Entomologische Versuche (Kleine Beitrage zur nahren Berichtigungen einiger Kaferarten mit 3 ausgemahften Kupfertafeln von Sturm J.). Wien, Austria.

Cruz, M., and I. Martínez. 2002. Data on nesting and preimaginal development in two Mexican species of Ataenius Harold, 1867 (Coleoptera, Scarabaeoidea, Aphodiidae; Eupariinae). Folia Entomologica Mexicana 41:1-5.

Curoe, D. J., and M. A. Morón. 2003. A new species of Promacropoides Sigwalt (Coleoptera: Scarabaeidae: Rutelinae) from Panamá. Zootaxa 312:1-8.

Dalman, J. W. 1824. Ephemerides entomologica. P. A. Norstedt, Stockholm.

Dejean, P. F. M. A. 1821. Catalogue de la Collection de Coléoptères de M. le Baron Dejean. Crevot Libraire, Paris, France.

Dejean, P. F. M. A. 1833. Catalogue des Coléoptères de la Collection de M. le Comte Dejean, Fascicles 1-2. Méquignon-Marvis Père et Fils, Paris.

Dejean, P. F. M. A. 1836. Catalogue des Coléoptères de la Collection de M. le Comte Dejean. Troisième Édition, Revue, Corrigée et Augmentée, Fascicles 1-4. Méquignon-Marvis Père et Fils, Paris, France.

Dellacasa, M. 1988. Contribution to a world-wide catalogue of Aegialiidae, Aphodiidae, Aulonocnemidae, Termitotrogidae. (part I). Memorie della Società Entomologica Italiana 66:1-455. [Dated 1987.].

Dellacasa, M., and Z. Stebnicka. 2001. A new genus for Oxyomus morosus Harold, 1869 (Eupariini) and redefinition of Oxyomus setosopunctatus A. Schmidt, 1911 (Aphodiini) (Coleoptera Scarabaeidae: Aphodiinae). Acta Zoologica Mexicana (Nueva Serie) 83:29-34.

Delgado, L., and J. Blackaller-Bages. 1997. A new Mexican species of Homoiosternus (Coleoptera: Melolonthidae; Rutelinae). Journal of the New York Entomological Society $105: 170-179$.

Delgado, L., A. Pérez, and J. Blackaller. 2000. Claves para determinar a los taxones genericos y supragenericos de Scarabaeoidea Latreille, 1802 (Coleoptera) de Mexico. Folia Entomologica Mexicana 110:33-87.

Deloya, C. 1994. Distribucion del genero Ataenius Harold, 1867 en Mexico (Coleoptera: Scarabaeidae: Aphodiinae: Eupariini). Acta Zoologica Mexicana (Nueva Serie) 61:43-56.

Dewailly, P. 1950. Coléoptères Melolonthini de Madagascar. Mémoires de l'Institut Scientifique de Madagascar, série A 4:209-454.

Deyrolle, H. 1863. Nouveau genre de Lucanide. Annales de la Société Entomologique de France series 4 3:485-487.

Deyrolle, H., and L. Fairmaire. 1878. Descriptions de Coléoptères recueillis par M. l'abbé David dans la Chine centrale. Annales de la Société Entomologique de France (5) $8: 87-140$.

Didier, R., and E. Séguy. 1953. Catalogue Illustré des Lucanides du Globe. Paul Lechevalier, Paris, France.

Dupont, H. 1832. Hétérosterne. Heterosternus. Dupont. Magasin de Zoologie 2: plate 10.

Endrödi, S. 1966. Monographie der Dynastinae (Coleoptera, Lamellicornia). I. Teil. Entomologische Abhandlungen Staatliches Museum für Tierkunde in Dresden $33: 1-457$.

Endrödi, S. 1985. The Dynastinae of the World. W. Junk, Dordrecht, Netherlands.

Endrödi, S., and M. Rakovič. 1981. Key to the species of South and south west African Aphodiinae. Folia Entomologica Hungarica 34:31-77.

Erichson, W. F. 1835. Neue Südamerikanische Käfergattungen aus der Familie der Blätterhörner. Archiv für Naturgeschichte 1:256-270. 
Erichson, W. F. 1840. Die Pachypoden, eine kleine Gruppe aus der Familie der Melolonthen. Entomographien 1:29-43.

Erichson, W. F. 1842. Beitrag zur Insecten-Fauna von Vandiemensland, mit besonderer Berücksichtigung der geographischen Verbreitung der Insecten. Archiv für Naturgeschichte 8:83-287.

Erichson, W. F. 1843. Bericht über die wissenschaftlichen Leistungen in der Naturgeschichte der Insecten, Arachniden, Crustaceen u. Entomostraceen während des Jahres 1842. Archiv für Naturgeschichte 9:149-288.

Erichson, W. F. 1847a. Conspectus Insectorum Coleopterum, quae in Republica Peruana observata sunt. Archiv für Naturgeschichte 13:67-185.

Erichson, W. F. 1847b. Naturgeschichte der Insecten Deutschlands, volume 3, part 5. Nicolaischen Buchhandlung, Berlin, Germany.

Erichson, W. F. 1848. Naturgeschichte der Insecten Deutschlands, volume 3, part 5. Nicolaischen Buchhandlung, Berlin, Germany.

Eschscholtz, J. F. 1818. Decades tres eleutheratorum novorum descripsit. Mémoires de l'Académie Impériale des Sciences de St. Pétersbourg 6:451-484.

Eschscholtz, J. F. 1822. Entomographien. O. Reimer, Berlin.

Evans, A. V. 1989. Revision of the genus Sparrmannia Laporte (Coleoptera: Melolonthidae: Melolonthinae). Journal of the Entomological Society of Southern Africa 52:11-44.

Evans, A. V. 2003. A checklist of the New World chafers (Coleoptera: Scarabaeidae: Melolonthinae). Zootaxa 211:1-458.

Evenhuis, N. L. 1997. Litteratura Taxonomica Dipterorum (1758-1930). Volume I-II. Backhuys Publishers, Leiden, Netherlands.

Evenhuis, N. L. 2003. Publication and dating of the journals forming the Annals and Magazine of Natural History and the Journal of Natural History. Zootaxa 385:1-68.

Fabricius, J. C. 1775. Systema Entomologiae, Sistens Insectorum Classes, Ordines, Genera, Species, Adiectis Synonymis, Locis, Descriptionibus, Observationibus. Officina Libraria Kortii, Flensburg and Leipzig.

Fabricius, J. C. 1792. Entomologiae Systematicae Emendatae et Auctae, volume 1, part 1. C. G. Proft, Copenhagen, Denmark.

Fabricius, J. C. 1798. Supplementum Entomologiae Systematicae. Proft et Storge, Copenhagen, Denmark.

Fabricius, J. C. 1801. Systema Eleutheratorum Secundum Ordines, Genera, Species: Adiectis Synonymis, Locis, Observationibus, Descriptionibus, volume 2. Impensis Bibliopolii Academici Novi, Kiel, Germany.

Fairmaire, L. 1850. Description d'un nouveau genre de lucanide. Annales de la Société Entomologique de France (series 2) 8:53-57.

Fall, H. C. 1901. A change of name. Canadian Entomologist 33:324.

Fallén, C. F. 1807. Observationes Entomologicae, part 3. Litteris Berlingianis, Lund.

Ferreira, M. C. 1953. Monografia dos Escarabaeídeos da Africa do Sul. Tribo-Scarabaeini. I Parte Sub-tribo Pachysomides. Boletím da Sociedade de Estudos da Provincia de Moçambique 23:1-87.

Fischer von Waldheim, G. 1823. Coleoptera quaedam exotica, descripta. Mémoires de la Société Impériale des Naturalistes de Moscou 6:254-267.

Fleming, J. 1821. Insecta. In: Supplement to the Fourth, Fifth, and Sixth Editions of the Encyclopadia Britannica, volume 5, part 1. Archibald Constable and Company, Edinburgh, Scotland.

Frey, G. 1974a. Ein neuer amerikanische Gattung der Tribus Pachydemini (Col. Melolonthidae). Entomologische Arbeiten aus dem Museum G. Frey 25:139-140.

Frey, G. 1974b. Ein neuer Trichinopus aus dem Museum Alexander König in Bonn (Col. Melolonthidae Pachydemini). Entomologische Arbeiten aus dem Museum G. Frey 25:342.

Frey, G. 1975. Eine neue südamerikanische Gattung und Tribus der Melolonthiden. Entomologische Arbeiten aus dem Museum G. Frey 26:84-85.

Gené, J. 1836. De quibusdam insectis sardiniae novis aut minus cognitis. Memorie della Reale Accademia della Scienze di Torino 39:161-199. 
Geoffroy, E. L. 1762. Histoire Abrégée des Insectes, volume 1. Calixte-Volland and Rémont, Paris, France.

Germain, P. 1897. Apuntes Entomolójicos. Agrupacion de los Taurocerastidae. Anales de la Universidad de Chile 98:287-300.

Germain, P. 1903. Apuntes Entomolójicos. Anales de la Universidad de Chile 112:343-365.

Gordon, R., and S. McCleve. 2003. Five new species of Euparixia Brown (Coleoptera: Aphodiidae: Eupariinae), with a revised key to species. Proceedings of the Entomological Society of Washington 105:685-697.

Gory, H., and A. Percheron. 1833. Monographie des Cétoines et Genres Voisins, Formant, dans les Familles Naturelles de Latreille, la Division des Scarabées Mélitophiles. J.-B. Baillière, Paris, France.

Gravely, F. H. 1914. An account of the oriental Passalidae (Coleoptera), based primarily on the collection in the Indian Museum. Memoirs of the Indian Museum 3:177-353, plates XI-XII.

Griffith, E., and E. Pidgeon. 1832. The Class Insecta Arranged by the Baron Cuvier, with Supplementary Additions to each Order. Volume 1, Whittaker, Treacher, and Co., London, U.K..

Guérin-Méneville, F. E. 1831. Insectes. In: Voyage Autour du Monde, Exécuté par Ordre du Roi, sur la Corvette de la Majesté, la Coquille, Pendant les Années 1822, 1823, 1824 et 1825, sous le Ministère et Conformément aux Instructions de S. E. M. Le Marquis de Clermont-Tonnerre, Ministre de la Marine; et Publié sous les Auspices de son Excellence Mgr le Cte de Chabrol, Ministre de la Marine et des Colonies M. L. I. Duperrey (ed.). Atlas (Histoire naturelle, Zoologie), Arthus Bertrand, Paris, France.

Guérin-Méneville, F. E. 1840. Description de quelques Coléoptères des côtes du détroit de Magellan. Revue Zoologique 1840:295-305.

Halffter, G. 1961. Monografia de las especies norteamericanas del genero Canthon Hoffsg. (Coleopt., Scarab.). Ciencia 20:225-320.

Halffter, G., and E. G. Matthews. 1966. The natural history of dung beetles of the subfamily Scarabaeinae (Coleoptera, Scarabaeidae). Folia Entomologica Mexicana 1214:1-312.

Hardy, A. R. 1978. Three new Pachydemini and a key to the species of the genus Phobetus (Coleoptera: Scarabaeidae). Coleopterists Bulletin 32:47-52.

Harold, E. 1861. Beiträge zur Kenntniss einiger coprophagen Lamellicornia. Berliner Entomologische Zeitschrift 5:92-115.

Harold, E. 1867a. Zur Kenntniss der Gattung Canthidium und ihrer nächsten Verwandten. Coleopterologische Hefte 1:1-61.

Harold, E. 1867b. Diagnosen neuer Coprophagen. Coleopterologische Hefte 1:76-83.

Harold, E. 1868. Die chilensischen Aphodiden. Berliner Entomologische Zeitschrift 11:278-282. [Dated 1867.].

Harold, E. 1869. Abänderungen vergebener Namen. Coleopterologische Hefte 5:122-125.

Harold, E. 1877. Enumération des Lamellicornes Coprophages rapportés de l'Archipel Malais, de la Nouvelle Guinée et de l'Australie boréale par M. M. J. Doria, O. Beccari et L. M. D'Albertis. Annali del Museo Civico di Storia Naturale di Genova 10:38-110.

Harpootlian, P. J. 2001. Scarab beetles (Coleopetera: Scarabaeidae) of South Carolina. Biota of South Carolina 2:1-157.

Harris, T. W. 1827. Minutes towards a history of some American species of Melolonthae particularly injurious to vegetation. Massachusetts Agricultural Journal $10: 1-12$.

Harris, T. W. 1841. A Report on the Insects of Massachusetts, Injurious to Vegetation. Folsom, Wells, and Thurston, Cambridge, U.K.

Heer, O. 1841. Fauna Coleopterorum Helvetica, part 1, fascicle 3. Orelii, Fuesslini et Sociorum, Zurich, Switzerland.

Heller, K. M. 1900. Neue Käfer von Celebes IV. Abhandlungen und Berichte des Königlichen Zoologischen und Anthropologisch-Ethnographischen Museums zu Dresden 9:1-46. 
Hellwig, J. C. L. 1792. Dritte Nachricht von neuen Gattungen im entomologischen System. Neues Magazin für die Liebhaber der Entomologie 1:385-408.

Heyden, L., E. Reitter, and J. Weise. 1883. Catalogus Coleopterorum Europae et Caucasi, editio tertia. Libraria Nicolai, Berlin, Germany.

Holloway, B. A. 1968. The relationship of Syndesus MacLeay and Sinodendron Schneider (Coleoptera: Lucanidae). New Zealand Journal of Science 11:264-269.

Holloway, B. A. 1972. The systematic position of the genus Diphyllostoma Fall (Coleoptera: Scarabaeoidea). New Zealand Journal of Science 15:31-38.

Holloway, B. A. 1997. Elytral surface structures as indicators of relationships in stag beetles, with special reference to the New Zealand species (Coleoptera: Lucanidae). New Zealand Journal of Zoology 24:47-64.

Hoffmannsegg, J. C. 1817. Entomologische Bemerkungen bei Gelegenheit der Abhandlungen über amerikanische Insecten. Zoologisches Magazin 1:8-56.

Hope, F. W. 1831. Synopsis of the new species of Nepaul insects in the collection of Major General Hardwicke. Zoological Miscellany 1:21-32.

Hope, F. W. 1833. On the characters of several new genera and species of Coleopterous insects. Proceedings of the Zoological Society of London 1:61-64.

Hope, F. W. 1837. The Coleopterists Manual, Containing the Lamellicorn Insects of Linneus and Fabricius. Henry G. Bohn, London, U.K.

Hope, F. W. 1839. A monograph on Mr. William Sharp MacLeay's coleopterous genus Euchlora. Proceedings of the Zoological Society of London 7:65-75.

Hope, F. W. 1840. Descriptions of some new insects collected in Assam, by William Griffith, Esq., Assistant Surgeon in the Madras Medical Establishment. Annals and Magazine of Natural History (series 1) 6:299-301.

Hope, F. W. 1841. Descriptions of some nondescript Lamellicorn beetles in his collection. Annals and Magazine of Natural History (series 1) 8:302-304.

Hope, F. W. 1842a. On some rare and beautiful Coleopterous insects from Silhet, the major part belonging to the collection of Frederic Parry, Esq., of Cheltenham. Proceedings of the Linnean Society of London 1:127-128.

Hope, F. W. 1842b. Observations on the Coleoptera of Port Essington, in Australia, with descriptions of the following new species. Annals and Magazine of Natural History series 1 volume 9:423-430.

Hope, F. W. 1843. Descriptions of the Coleopterous insects sent to England by Dr. Cantor from Chusan and Canton, with observations on the entomology of China. Annals and Magazine of Natural History (series 1) 11:62-66.

Hope, F. W. 1845. On the entomology of China, with descriptions of the new species sent to England by Dr. Cantor from Chusan and Canton. Transactions of the Entomological Society of London 4:4-17.

Horn, G. H. 1866. Descriptions of some new genera and species of Central American Coleoptera. Proceedings of the Academy of Natural Sciences of Philadelphia 18:397-401.

Houston, W. W. K., and T. A. Weir. 1992. Melolonthinae [pp. 174-358]. In: Zoological Catalogue of Australia. Coleoptera: Scarabaeoidea, volume 9. W. W. K. Houston and T. A. Weir (eds.). AGPS, Canberra, Australia.

Howden, H. F. 1973. Scarabatermes amazonensis, a new genus, new species, of termitophilous Scarabaeidae (Coleoptera). Canadian Entomologist 105:29-33.

Howden, H. F. 1997. Podolasiini Howden, new tribe, and a revision of the included genera, Podolasia Harold and Podostena Howden, new genus (Coleoptera: Scarabaeidae: Melolonthinae). Coleopterists Bulletin 51:223-255.

Howden, H. F. 2001. A new tribe of Hybosorinae with a description of a new species of Callosides Howden (Coleoptera: Scarabaeidae). Coleopterists Bulletin 55:199-204.

Howden, H. F., and J. B. Cooper. 1977. The generic classification of the Bolboceratini of the Australian region, with descriptions of four new genera (Scarabaeidae: Geotrupinae). Australian Journal of Zoology Supplementary Series 50:1-50.

Howden, H. F., and B. D. Gill. 1988. A fourth genus of unusually modified Ceratocanthinae (Coleoptera: Scarabaeidae) from South America. Canadian Journal of Zoology 66:2077-2079. 
Howden, H. F., and B. D. Gill. 2000. Tribes of New World Ceratocanthinae, with keys to genera and descriptions of new species (Coleoptera: Scarabaeidae). Sociobiology 35:281-329.

Howden, H. F., and A. R. Hardy. 1971. Generic placement and adult behaviour of the genus Leptohoplia Saylor (Coleoptera: Scarabaeidae). Proceedings of the Entomological Society of Washington 73:337-341.

Howden, H. F., and J. F. Lawrence. 1974. The New World Aesalinae, with notes on the North American lucanid sub-families (Coleoptera, Lucanidae). Canadian Journal of Zoology 52:1505-1510.

Howden, H. F., and A. Martínez. 1963. The new tribe Athyreini and its included genera (Coleoptera: Scarabaeidae, Geotrupidae). Canadian Entomologist 95:345-352.

Howden, H. F., and R. I. Storey. 1992. Phylogeny of the Rhyparini and the new tribe Stereomerini with descriptions of new genera and species (Coleoptera; Scarabaeidae; Aphodiinae). Canadian Journal of Zoology 70:1810-1823.

Iablokoff-Khnzorian, S. M. 1977. Über die Phylogenie der Lamellicornia (Insecta, Coleoptera). Entomologische Abhandlungen Staatliches Museum für Tierkunde in Dresden 41:135-200.

Illiger, J. K. W. 1803. Verzeichniss der in Portugall einheimischen Käfer. Erste Lieferung. Magazin für Insektenkunde 2:186-258.

Imhoff, L. 1856. Versuch einer Einführung in das Studium der Koleoptern. Schweighauser'sche Buchdruckerei, Basel, Switzerland.

International Commission on Zoological Nomenclature (ICZN). 1962. Opinion 621. Phaenomerididae Ohaus, 1913, and Phaenomerina Faust, 1898 (Insecta, Coleoptera); addition to the official list. Bulletin of Zoological Nomenclature 19:74-75.

International Commission on Zoological Nomenclature (ICZN). 1989. Opinion 1546. Chelonus Panzer, 1806 (Insecta, Hymenoptera) and Anomala Samouelle, 1819 (Insecta, Coleoptera): names conserved. Bulletin of Zoological Nomenclature 46:149-150.

International Commission on Zoological Nomenclature (ICZN). 1994. Opinion 1754. Histoire abrégée des insectes qui se trouvent aux environs de Paris (Geoffroy, 1762): some generic names conserved (Crustacea, Insecta). Bulletin of Zoological Nomenclature 51:58-70.

International Commission on Zoological Nomenclature (ICZN). 1999. International Code of Zoological Nomenclature, Fourth Edition. International Commission on Zoological Nomenclature, The Natural History Museum, London, U.K.

International Commission on Zoological Nomenclature (ICZN). 2004. Opinion 2079 (Case 2926). Trichia Hartmann, 1840 (Mollusca, Gastropoda): proposed conservation; and Trichiinae Lozek, 1956 (Gastropoda): proposed emendation of spelling to Trichiainae, so removing the homonymy with Trichiidae Fleming, 1821 (Insecta, Coleoptera) not approved. Bulletin of Zoological Nomenclature 61:177-181.

Jacquelin du Val, P. N. C., and L. Fairmaire. 1859. Genera des Coléoptères d'Europe, volume 3. A. Deyrolle, Paris, France.

Jameson, M. L. 1990. Revision, phylogeny and biogeography of the genera Parabyrsopolis Ohaus and Viridimicus new genus (Coleoptera: Scarabaeidae: Rutelinae). Coleopterists Bulletin 44:377-422.

Jameson, M. L. 1998. Phylogenetic analysis of the subtribe Rutelina and revision of the Rutela generic groups (Coleoptera: Scarabaeoidea: Rutelinae: Rutelini). Bulletin of the University of Nebraska State Museum 14:1-184. [Dated 1997.].

Jameson, M. L., and S. J. Hawkins. 2005. Synopsis of the genera of Geniatini (Coleoptera: Scarabaeidae: Rutelinae) with an annotated catalog of species. Zootaxa 874:1-76.

Jameson, M. L., A. Paucar-Cabrera, and A. Solís. 2003. Synopsis of the New World genera of Anomalini (Coleoptera: Scarabaeidae: Rutelinae) and description of a new genus from Costa Rica and Nicaragua. Annals of the Entomological Society of America 96:415-432.

Janson, O. E. 1881. Notes of new or little known Cetoniidae. Cistula Entomologica 2:603-611, plate 11 . 
Janssens, A. 1946. Contribution a l'étude des Coléoptères Lamellicornes coprophages. Bulletin du Musée Royal d'Histoire Naturelle de Belgique 22:1-13.

Jekel, H. 1866. Essai sur la classification naturelle des Geotrupes Latreille et descriptions d'espèces nouvelles. Annales de la Société Entomologique de France 4:513-618. [Dated 1865.].

Kaup, J. 1868a. Prodromus zu einer Monographie der Passaliden. Coleopterologische Hefte $3: 4-32$.

Kaup, J. 1868b. Prodromus zu einer Monographie der Passaliden. Coleopterologische Hefte $4: 1-31$.

Kaup, J. 1869. Prodromus zu einer Monographie der Passaliden. Coleopterologische Hefte $5: 1-40$.

Kaup, J. 1871. Monographie der Passaliden. Berliner Entomologische Zeitschrift 15:1-125.

Keith, D. 2002. Sur quelques Pachydeminae (Coleoptera, Melolonthinae). Lambillionea 102:36-42.

Keith, D. 2005. Les Elaphocera du basin Mediterraneen oriental a hanches posterieures saillantes en pointe: deux nouvelles especes de Grece (Col. Melolonthidae Pachydeminae). Lambillionea 105:242-244.

Keith, D., and O. Montreuil. 2004. Révision des genres Otoclinius Brenske 1896, Falsotoclinius n. gen. et Tanyproctoides Petrovitz 1971 (Coleoptera: Melolonthidae: Pachydeminae). Annales de la Société Entomologique de France 40:213-225.

Kikuta, T. 1986. On the higher taxa of the stag beetle family Lucanidae [pp. 131-138]. In: Papers on Entomology Presented to Professor Takeshiko Nakane in Commemoration of his Retirement. Japanese Society of Coloepterology, Tokyo, Japan.

Kirby, W. 1819a. A century of insects, including several new genera described from his cabinet. Transactions of the Linnean Society of London 12:375-453. [Dated 1818.].

Kirby, W. 1819b. A description of several new species of insects collected in New Holland by Robert Brown. Transactions of the Linnean Society of London 12:454 482. [Dated 1818.].

Kirby, W. 1825. A description of such genera and species of insects, alluded to in the "Introduction to Entomology" of Messrs. Kirby and Spence, as appear not to have before sufficiently noticed of described. Transactions of the Linnean Society of London 14:563-572.

Kirby, W. 1827. A description of some new genera and species of petalocerous Coleoptera. Zoological Journal 3:145-158.

Kirby, W. 1828. A description of some Coleopterous insects in the collection of the Rev. F.W. Hope, F.L.S. Zoological Journal 3:520-525.

Kirby, W. 1837. The Insects. In: Fauna Boreali-Americana, part 4. J. Richardson, W. Swainson, and W. Kirby (eds.). Josiah Fletcher, Norwich, U.K.

Kirby, W., and W. Spence. 1828. An Introduction to Entomology, volume 4. Fifth Edition. Longman, Rees, Orme, Brown, and Green, London, U.K.

Klug, J. C. F. 1838. Ueber zwei neue Käfergattungen aus Madagaskar. Archiv für Naturgeschichte 4:67-72.

Klug, J. C. F. 1845. Coleoptera XV-XVI, 8 unnumbered pages, plate XLI-XLII. In: Symbolae Physicae seu Icones et Descriptiones Insectorum quae ex itinere Africam Borealem et Asiam Occidentalem, volume 5. C. G. Eherenberg (ed.). G. Reimeri, Berlin.

Knoch, A. W. 1801. Neue Beyträge zur Insectenkunde. Leipzig, Germany.

Kolbe, H. J. 1894. Ueber einige neue, von Herrn J. Fruhstorfer auf Java entdeckte Coleopteren. Stettiner Entomologische Zeitung 55:3-11.

Kolbe, H. J. 1897. Beiträge zur Kenntniss der melitophilen Lamellicornier (Coleoptera). VIII. Die afrikanischen Genera und Spezies der Valgiden. Stettiner Entomologische Zeitung 58:184-215.

Kolbe, H. J. 1904. Gattungen und Arten der Valgiden von Sumatra und Borneo. Stettiner Entomologische Zeitung 65:3-57.

Kolbe, H. J. 1905. Über die Lebensweise und die geographische Verbreitung der coprophagen Lamellicornier. Zoologischen Jahrbüchern Supplement 8:475-594. 
Kolbe, H. 1907. Neue Coprophagen aus Afrika. 1. Annales de la Société Entomologique de Belgique 51:25-31.

Kraatz, G. 1880a. Genera nova Cetonidarum. Entomologische Monatsblätter 2:17-32.

Kraatz, G. 1880b. Genera Cetonidarum Australiae. Deutsche Entomologische Zeitschrift 24:177-214.

Kraatz, G. 1882a. Ueber die Gattung Clinteria Burm. Deutsche Entomologische Zeitschrift 26:49-51.

Kraatz, G. 1882b. Die africanischen Leucoceliden und die ihnen zunächst verwandten Gattungen der Cetoniden. Deutsche Entomologische Zeitschrift 26:65-78.

Kraatz, G. 1883. Ueber die Gattung Valgus und eine Anzahl neuer Arten derselben. Deutsche Entomologische Zeitschrift 27:371-379.

Kraatz, G. 1895. Acanthovalgus nov. gen. Valginorum. Deutsche Entomologische Zeitschrift 1895:444.

Krikken, J. 1975. Telochilus freyi, a new genus and species from Nigeria (Coleoptera: Cetoniidae). Zoologische Mededelingen 49:21-25.

Krikken, J. 1984. A new key to the suprageneric taxa in the beetle family Cetoniidae, with annotated lists of the known genera. Zoologische Verhandelingen 210:1-75.

Kugelann, J. G., and J. K. W. Illiger. 1798. Verzeichniss der Käfer Preussens. Johann Jacob Gebauer, Halle, Germany.

Kuwert, A. 1891. Systematische Uebersicht der Passaliden-Arten und Gattungen. Deutsche Entomologische Zeitschrift 1891:161-192.

Kuwert, A. 1896. Die Passaliden dichotomisch bearbeitet. Novitates Zoologicae 3:209-231.

Lacordaire, J. T. 1856. Histoire Naturelle des Insectes. Genera des Coléoptères, vol. 3. Librairie Encyclopédique de Roret, Paris, France.

Lacroix, J. P. 1979. Contributions à l'étude des Coléoptères lucanides du globe: deux genres nouveaux et onze espèces inédites (Chiasognathinae, Lucaninae, Chalcodinae, Cladognathinae, Dorcinae). Bulletin et Annales de la Société Royal Belge d'Entomologie 114:249-294. [Dated 1978.].

Lacroix, M. 1989. Insectes Coléoptères Melolonthidae (1re partie). Fauna de Madagascar $73: 1-302$.

Lacroix, M. 1997. Insectes Coléoptères Hopliidae (1ère partie). Fauna de Madagascar $88: 1-400$.

Lacroix, M. 1998. Insectes Coléoptères Hopliidae (2e partie). Fauna de Madagascar 88:401-755.

Lacroix, M. 2001. Pachydeminae de l'Est africain (Kenya et Tanzanie) (Coleoptera, Melolonthidae). Coléoptères 7:173-226.

Lacroix, M. 2003. Contribution à la connaissance des Pachydeminae africains. III. Nouveau genre et nouvelles espéces (Coleoptera, Melolonthidae). Coléoptères 9:63-82.

Lacroix, M. 2004. Contribution à la connaissance des Pachydeminae africains, IV. Nouvelle espèces (Coleoptera, Melolonthidae). Coléoptères 10:107-118.

Lacroix, M. 2005. Contribution à la connaissance des Pachydeminae africains, V. Nouvelles espèces de Oedanomerus Waterhouse (Coleoptera, Melolonthidae). Coléoptères 11:51-65.

van Laicharting, J. N. 1781. Verzeichniss und Beschreibung der Tyroler Insecten. 1. Theil Käferartige Insecten, volume 1. Johann Caspar Füessly, Zürich, Switzerland.

Lamarck, J. B. 1801. Systêma des Animaux sans Vertèbres. Muséum d'Histoire Naturelle, Paris, France.

Landin, B.-O. 1949. Entomological results from the Swedish expedition 1934 to Burma and British India; Coleoptera: Lamellicornia; Fam. Scarabaeidae collected by René Malaise. Arkiv för Zoologi 1:3-9.

Landin, B.-O. 1960. Report no. 5 from the Lund University expedition in 1957 to the Azores and Madeira. The Lamellicorn beetles of the Azores (Coleoptera) with some reflections on the classification of certain Aphodiini. Boletim do Museu Municipal do Funchal 13:49-84.

van Lansberge, J. W. 1874a. Ennearabdus, gen. nov.; Synapsis Ritsemae Lansb. Annales de la Société Entomologique de Belgique 17:CXLIII-CXLIV. 
van Lansberge, J. W. 1874b. Observations sur la classification des Lamellicornes coprophages. Annales de la Société Entomologique de Belgique 17:177-193.

van Lansberge, J. W. 1875. Monographie des Onitides. Annales de la Société Entomologique de Belgique 18:5-148.

Laporte, F. L. 1832a. Mémoire sur cinquante espèces nouvelles ou peu connues d'insectes. Annales de la Société Entomologique de France 1:386-415.

Laporte, F. L. 1832b. Pachydeme. Pachydema. Laporte. Magasin de Zoologie 2: plate 37.

Laporte, F. L. 1832c. Trochale. Trochalus. Laporte. Magasin de Zoologie 2: plate 44.

Laporte, F. L. (Comte de Castelnau). 1840. Histoire Naturelle des Insectes Coléoptères (volume 2 of Histoire Naturelle des Animaux Articulés). P. Duménil, Paris, France.

Latreille, P. A. 1797. Précis des Caractères Génériques des Insectes, Disposés dans un Ordre Naturel. F. Bourdeaux, Paris, France.

Latreille, P. A. 1802. Histoire Naturelle, Genérale et Particulière, des Crustacés et des Insectes, volume 3. F. Dufart, Paris, France.

Latreille, P. A. 1804. Histoire Naturelle, Genérale et Particulière, des Crustacés et des Insectes, volume 10. F. Dufart, Paris, France.

Latreille, P. A. 1807. Genera Crustaceorum et insectorum Secundum Ordinem Naturalem in Familias Disposita, Iconibus Exemplisque Plurimis Explicata, volume 2. Amand Koenig, Paris, France.

Latreille, P. A. 1825. Familles Naturelles du Règne Animal, Exposées Succinctement et dans un ordre analytique, avec l'Indication de leurs Genres. J.-B. Baillière, Paris, France.

Latreille, P. A. 1829. Le Règne Animal Distribué d'Après son Organisation, pour Servir de Base à l'Histoire Naturelle des Animaux et d'Introduction à l'Anatomie Comparée. Par M. Le Baron Cuvier, avec Figures Dessinées d'Après Nature. Nouvelle Édition, Revue et Augmentée. Tome IV. Crustacés, Arachnides et Partie des Insectes. Déterville, Paris, France.

Lawrence, J. F., and A. F. Newton. 1995. Families and subfamilies of Coleoptera (with selected genera, notes, references and data on family-group names) [pp. 779-1006]. In: Biology, Phylogeny, and Classification of Coleoptera: Papers Celebrating the 80th Birthday of Roy A. Crowson. J. Pakaluk and S. A. Slipinski (eds.). Muzeum i Instytut Zoologii PAN, Warszawa, Poland.

Leach, W. E. 1815a. Entomology [pp. 57-172]. In: Edinburgh Encyclopaedia, volume 9, part 1 Brewster (ed.), Edinburgh, Scotland.

Leach, W. E.. 1815b. Rutela [pp. 43-44, plate 75]. In: The Zoological Miscellany; Being Descriptions of New, or Interesting Animals, (W. E. Leach. author). B. McMillan, London, U.K. [Anoplognathus validated in the "Index Systematicus" on page 156.]

Lebis, E. 1953. Révision des Canthoninae de Madagascar (Col. Scarabaeidae). Mémoires de l'Institut Scientifique de Madagascar, série 3:107-252.

LeConte, J. L. 1856a. Synopsis of the Melolonthidae of the United States. Journal of the Academy of Natural Sciences of Philadelphia (series 2) 3:225-288.

LeConte, J. L. 1856b. Notice of three genera of Scarabaeidae found in the United States. Proceedings of the Academy of National Sciences of Philadelphia 8:19-25.

LeConte, J. L. 1861. Classification of the Coleoptera of North America. Prepared for the Smithsonian Institution. Smithsonian Miscellaneous Collections 3:i-xxv + 1-214.

LeConte, J. L. 1874. Descriptions of new Coleoptera chiefly from the Pacific slope of North America. Transactions of the American Entomological Society 5:43-72.

Le Guillou, E. J. F. 1844. Description de vingt insects Coléoptères recueillis pendant le voyage autour du monde de l'Astrolabe et la Zélée. Revue Zoologique 7:220-225.

LePeletier, A. L. M., and J. G. A. Serville. 1828a. Scarabé, Scarabaeus [pp. 346-382]. In: Encyclopédie Méthodique. Histoire Naturelle. Entomologie, ou Histoire Naturelle des Crustaces, des Arachnides et des Insectes, volume 10, part 2. P. A. Latreille, A. L. M. LePeletier, J. G. A. Serville, and F. E. Guérin-Méneville (eds.). Mme veuve Agasse, Paris, France.

LePeletier, A. L. M., and J. G. A. Serville. 1828b. Trichie, Trichius [pp. 701-704]. In: Encyclopédie Méthodique. Histoire Naturelle. Entomologie, ou Histoire Naturelle des Crustaces, des Arachnides et des Insectes, volume 10, part 2 P. A. Latreille, A. L. M. 
LePeletier, J. G. A. Serville, and F. E. Guérin-Méneville (eds.). Mme veuve Agasse, Paris, France.

Lewis, G. 1895. On the Lamellicorn Coleoptera of Japan, and notices of others. Annals and Magazine of Natural History (series 6) 16:374-408.

Linnaeus, C. 1758. Systema Naturae per Regna Tria Naturae, Secundum Classes, Ordines, Genera, Species, cum Characteribus, Differentiis, Synonymis, Locis, edition 10, volume 1. Laurentii Salvii, Stockholm, Sweden.

López Colón, J. I. 1986. Los Pachydemini de las Islas Canarias (Col. Scarabaeoidea). Bolletin del Grupo Entomologico de Madrid 2:83-106.

López Colón, J. I. 1989. Sobre la diferenciación de los taxones a nivel supraespecífico de los Pachydemini canarios (Coleoptera, Melolonthidae). Bolletino del Museo Regionale di Scienze Naturali di Torino 7:297-302.

Machatschke, J. W. 1959. Phylogenetische Untersuchungen über die Sericini (sensu Dalla Torre 1912) (Coleoptera: Lamellicornia, Melolonthidae). Beiträge zur Entomologie 9:730-746.

Machatschke, J. W. 1971. Vier neue Anomala-Arten aus Gabun (Coleoptera, Lamellicornia, Rutelinae, Anomalini). Entomologische Arbeiten aus dem Museum G. Frey 22:136-149.

Machatschke, J. W. 1972. Scarabaeoidea: Melolonthidae, Rutelinae. Coleopterum Catalogus Supplementa 66:1-361.

Machatschke, J. W. 1973a. Eine neue Anomala aus Äthiopien (Coleoptera: Lamellicornia, Melolonthidae, Rutelinae, Anomalini). Entomologische Arbeiten aus dem Museum G. Frey 24:249-254.

Machatschke, J. W. 1973b. Eine neue Rhinyptia (Pararhinyptia) aus Gabon (Coleoptera: Lamellicornia, Melolonthidae, Rutelinae, Anomalini). Entomologische Arbeiten aus dem Museum G. Frey 24:280-283.

MacLeay, W. S. 1819. Horre Entomologica: or Essays on the Annulose Animals, volume 1, part 1. S. Bagster, London, U.K.

MacLeay, W. S. 1821. Hora Entomologica: or Essays on the Annulose Animals, volume 1, part 2. S. Bagster, London, U.K.

MacLeay, W. S. 1838. Illustrations of the Annulosa of South Africa. In: Illustrations of the Zoology of South Africa; Consisting Chiefly of Figures and Descriptions of the Objects of Natural History Collected During an Expedition into the Interior of South Africa, in the Years 1834, 1835, and 1836. Invertebratae, volume 5. A. Smith (ed.). Smith, Elder and Co., London, U.K.

Madge, R. B. 1989. A catalogue of the family-group names in the Geodephaga, 1758-1985 (Coleoptera: Carabidae s. lat.). Entomologica Scandinavica 19:459-474.

Maes, J.-M. 1992a. Lista de los Lucanidae (Coleoptera) del Mundo. Revista Nicaraguense de Entomologia 22A:1-60.

Maes, J.-M. 1992b. Lista de los Lucanidae (Coleoptera) del Mundo. Revista Nicaraguense de Entomologia 22A:61-121.

Mannerheim, C. G. 1829. Description de quarante nouvelles espèces de scarabéides du Brésil. Mémoires de la Société Impériale des Naturalistes de Moscou 7:31-80, plate 1-2.

Martínez, A. 1951. Scarabaeidae nuevos o poco conocidos II. Misión de Estudios de Patología Regional Argentina 22:23-36.

Martínez, A. 1968. Insectos nuevos o poco conocidos XIII: Ceratocanthini nom. nov. para Acanthocerini (Coleoptera, Scarabaeidae, Troginae). Revista de la Sociedad Entomológica Argentina 30:9-16. [Dated 1967.].

Martínez, A. 1972. Un nuevo genero y especie de Pachydemini Chileno (Col. Scarabaeidae, Melolonthinae). Entomologische Arbeiten aus dem Museum G. Frey 23:86-92.

Martínez, A. 1973. El genero Neogutierrezia Martinez, 1953 (Col. Scarab. Melolonth. Pachydemini). Anales de la Sociedad Científica Argentina 195:25-41.

Martínez, A. 1975. Contribución al conocimiento de los Pachydemini neotropicales (Col. Scarabaeidae, Melolonthinae). Entomologische Arbeiten aus dem Museum G. Frey 26:227-251.

Martínez, A. 1982. Un nuevo genero de Pachydemini Argentino (Col. Scarab. Melolonthinae). Revista Sociedad Entomologica Argentina 41:89-91. 
Martínez, M. I., C. Deloya, and M. Dellacasa. 2001. Anatomical and functional data on female and male reproductive systems of some dung beetle species of Aphodiinae and Eupariinae of Mexico (Coleoptera: Scarabaeoidea: Aphodiidae). Proceedings of the Entomological Society of Washington 103:227-248.

Masumoto, K., and T. Ochi. 2005. New records of Ataenius peregrinator Harold (Scarabaeidae, Aphodiinae, Eupariini) from Okinawa Island. Elytra 33:490.

Mateu, J. 1966. Un nouveau Corythoderini termitophile récolté dans l'Ennedi (Col. Scarabaeidae Aphodiinae). Bulletin de l'Institut Fondamental d'Afrique Noire 28:717-721.

Medvedev, S. I. 1951. Zhestkokrylye 10(1). Plastinchatousye (Scarabaeidae), podsem. Melolonthinae. Fauna SSSR (new series) 46. Zoologicheskiy Institut Akademia Nauk SSSR, Moscow, USSR.

Medvedev, S. I. 1952. Zhestkokrylye 10(2). Plastinchatousye (Scarabaeidae), podsem. Melolonthinae. Fauna SSSR (new series) 52. Zoologicheskiy Institut Akademia Nauk SSSR, Moscow, USSR.

Ménétries, E. 1832. Catalogue Raisonné des Objets de Zoologie Recueillis dans un Voyage au Caucase et Jusqu'aux Frontières Actuelles de la Perse Entrepris par Ordre de S. M. l'Empereur. L'Académie Impériale des Sciences, St. Petersburg, Russia.

Micó, E., B. Gómez, and E. Galante. 2006. The Mesoamerican genus Yaaxkumukia: biogeography and descriptions of new species (Coleoptera: Rutelidae). Annals of the Entomological Society of America 99:1-6.

Micó, E., M. A. Morón, and E. Galante. 2003. New larval descriptions and biology of some New World Anomalini beetles (Scarabaeidae: Rutelinae). Annals of the Entomological Society of America 96:597-614.

Micó, E., J. R. Verdú, and E. Galante. 2001. Larval morphology of some Anisopliini grain beetles with a key to their larvae (Coleoptera: Scarabaeoidea: Rutelidae: Anomalinae). European Journal of Entomology 98:311-320.

Miessen, G., and M. Cludts. 2002. Les Pachydema Castelnau, 1832 nord-africaines des collections entomologiques de l'institut royal des Sciences naturelles de Belgique (I.R.Sc.N.B. - K.B.I.N.) (Coleoptera Scarabaeoidea Melolonthinae Pachydemini). Bulletin de la Société Royale Belge d'Entomologie 138:59-62.

Mikšić, R. 1976. Monographie der Cetoniinae der Paläarktischen und Orientalischen Region, volume 1. Forstinstitut in Sarajevo, Sarajevo, Yugoslavia.

Miwa, Y. 1931. A study on the lucanid-Coleoptera from the Japanese Empire 1. Transactions of the Natural History Society of Formosa 21:315-325.

Mjöberg, E. 1917. Results of Dr. E. Mjöberg's Swedish scientific expeditions to Australia 1910-1913. 14. Cetoniidae, Rutelidae, Passalidae, Chysomelidae: subfam. Sagrinae, Cassidinae, Hispinae. Arkiv för Zoologi 11:1-19.

Montreuil, O. 2003. Tosevskiana Pavićević, 1985, an enigmatic genus of European Melolonthinae Rhizotrogini removed from Pachydeminae (Coleoptera: Melolonthidae). Annales de la Société Entomologique de France 39:207-210.

Morón, M. A. 1979. Fauna de Coleópteros Lamelicornios de la Estación de Biología Tropical, "Los Tuxtlas", Veracruz, Unam. México. Anales del Instituto de Biologia, Universidad Nacional Autónoma de México, Serie Zoología 1:375-454.

Morón, M. A. 1983. A revision of the subtribe Heterosternina (Coleoptera, Melolonthidae, Rutelinae). Folia Entomológica Mexicana 55:31-101.

Morón, M. A. 1987. Adiciones a los Heterosternina (Coleoptera: Melolonthidae, Rutelinae). Folia Entomológica Mexicana 73:69-87.

Morón, M. A. 1990. Rutelini 1. Los Coleópteros de Mundo/The Beetles of the World $10: 1-145$.

Morón, M. A. 1991. Los escarabajos fitófagos, un ejemplo de la riqueza biótica de Mesoamérica (Coleoptera: Scarabaeoidea). Giornale Italiano di Entomologia 5:209-218.

Morón, M. A. 1993. Catalogo de tipos depositados en la coleccion M. A. Morón Xalapa, Veracruz, Mexico (M-XAL) (Insecta, Coleoptera: Lamellicornia). Sociedad Mexicana de Entomología, Xalapa, Mexico. 
Morón, M. A. 1994. Fauna de Coleoptera Lamellicornia en las montañas del noreste de Hidalgo, Mexico. Acta Zoológica Mexicana 63:7-59.

Morón, M. A. 1997. Capítulo 2, Rutelinae. In: Atlas de los Escarabajos de México; Coleoptera: Lamellicornia; Vol. I Familia Melolonthidae. M. A. Morón, B. C. Ratcliffe, and C. Deloya (eds.). Sociedad Mexicana de Entomología, Xalapa, México.

Morón, M. A., and J. Blackaller. 1997. Melolonthidae y Scarabaeidae [pp. 227-243]. In: Historia Natural de Los Tuxtlas. E. González Soriano, R. Dirzo, and R. C. Vogt (eds.). Universidad Nacional Autónoma de México, México City, Mexico.

Morón, M. A., C. Deloya, A. Ramírez-Campos, and S. Hernández-Rodríguez. 1998. Fauna de Coleoptera Lamellicornia de la region de Tepic, Nayarit, Mexico. Acta Zoológica Mexicana 75:73-116.

Morón, M. A., and H. F. Howden. 1992. A second species of Plesiosternus Morón with notes on other Heterosternina (Coleoptera: Scarabaeidae: Rutelinae). Coleopterists Bulletin 46:15-19.

Morón, M. A., and H. F. Howden. 2001. New species in the genus Dilophochila Bates (Coleoptera: Melolonthidae: Rutelinae: Anomalini). Coleopterists Bulletin 55:51-64.

Morón, M. A., and G. Nogueira. 2000. Third stage instar larva and pupa of Paraheterosternus luedeckei (Becker) (Coleoptera: Melolonthidae; Rutelinae). Journal of the Kansas Entomological Society 73:62-67.

Morón, M. A., F. J. Villalobos, and C. Deloya. 1985. Fauna de Coleopteros Lamelicornios de Boca del Chajul, Chiapas, Mexico. Folia Entomológica Mexicana 66:57-118.

Morón-Ríos, A., and M. A. Morón. 2001. La fauna de Coleoptera Melolonthidae de la reserva de la biósfera "El Triunfo", Chiapas, México. Acta Zoológica Mexicana $84: 1-25$

Moser, J. 1911. Neue Cremastochiliden von Afrika und Yunnan. Annales de la Société Entomologique de Belgique 55:134-144.

Motschulsky, V. 1858. Insectes du Japon. Études Entomologiques 6:25-41. [Dated 1857.].

Mulsant, E. 1842. Histoire Naturelle des Coléoptères de France. Lamellicornes. Maison, Libraire, Paris, France.

Mulsant, E. 1851. Description de deux nouvelles espèces de Coléoptères de la tribu des Lamellicornes, dont l'une sert à former un nouveau genre dans la famille des Trogidiens. Mémoires de l'Académie Nationale des Sciences, Belles-Lettres et Arts de Lyon. Classe de Sciences 1:138-140.

Mulsant, E., and C. Rey. 1870. Tribu des Lamellicornes. Annales de la Société d'Agriculture, Sciences et Industries de Lyon (4)2:241-650.

Mulsant, E., and C. Rey. 1871. Tribu des Lamellicornes. Annales de la Société d'Agriculture, Sciences et Industries de Lyon (4)3:155-480.

Newman, E. 1840. Descriptions of some new species of coleopterous insects. Magazine of Natural History (series 2) 4:362-368.

Newton, A. F. Jr., and M. K. Thayer. 1992. Current classification and family-group names in Staphyliniformia (Coleoptera). Fieldiana, Zoology (New Series) 67:1-92.

Nikolajev, G. V. 1970. [Taxonomic position of groups included in the subfamily Geotrupinae (Col., Scarabaeidae)] [pp. 31-34]. In: Materials of the Second Scientific Session of Young Specialists and PhD Candidates (Thesis of Lectures). Kazakhstan, Russia, [In Russian.]

Nikolajev, G. V. 1990. [The usage of the particularities of wing venation for clarification of the system of Lamellicornia beetles] [pp. 98-99]. In: Advances of Entomology in USSR: Coleoptera. Proceedings of the X Meeting of the All-Soviet Entomology Society, Leningrad, September 11-15, 1989. G. S. Medvedev and B. A. Korotyaev (eds.). USSR Academy of Sciences Zoology Institute, Leningrad, USSR, [In Russian.]

Nikolajev, G. V. 1992. [Taxonomic characters and generic composition of Mesozoic Scarabaeidae (Coleoptera)]. Paleontologicheskii Zhurnal 1992: 75-88. English translation: Paleontological Journal 26:96-111, 1992. [In Russian.] 
Nikolajev, G. V. 1995a. [New data on the systematics of the subfamily Ochodaeinae (Coleoptera, Scarabaeidae)]. Zoologicheskiy Zhurnal 74: 72-82. English translation: Entomological Review 75:113-123, 1996. [In Russian.]

Nikolajev, G. V. 1995b. [A new subfamily of lamellicorn beetles (Coleoptera, Scarabaeidae) from the Lower Cretaceous of Transbaikalia and its phylogenetic relationships]. Paleontologicheskii Zhurnal 1995(2), 147-151. English translation: Paleontological Journal 29:185-192, 1995. [In Russian.]

Nikolajev, G. V. 1996. [Lamellicorn beetle species (Coleoptera, Scarabaeidae) with multistriate elytra, from the Lower Cretaceous Baisa locality, Transbaikalia]. Paleontologicheskii Zhurnal 1996: 91-99. English translation: Paleontological Journal 30:217-224, 1996. [In Russian.]

Nikolajev, G. V. 1998. [Pleurostict Lamellicorn beetles (Coleoptera, Scarabaeidae) from the Lower Cretaceous of Transbaikalia]. Paleontologicheskii Zhurnal 1998: 77-84. English translation: Paleontological Journal 32:513-520, 1998. [In Russian.].

Nikolajev, G. V. 1999a. [On the polyphyly of the subfamily Penichrolucaninae (Coleoptera, Lucanidae), with the erection of the new monotypic tribe Brasilucanini]. Tethys Entomological Research 1999:171-172. [In Russian.]

Nikolajev, G. V. 1999b. [New data on the systematics of the scarab beetles of the subfamily Hybosorinae (Coleoptera, Scarabaeidae): the establishment of the new tribe comprising four monotypic South American genera, and description of some new taxa from the Lower Cretaceous of Transbaikalia]. Tethys Entomological Research 1999:173-182. [In Russian.]

Nikolajev, G. V. 2000a. [A new subfamily of Lamellicorn beetles (Coleoptera, Scarabaeoidea) from the lower Cretaceous of Transbaikalia and Mongolia, and its position within the superfamily]. Paleontologicheskii Zhurnal 2000:63-66. [In Russian.]

Nikolajev, G. V. 2000b. New subfamily of the stag beetles (Coleoptera: Scarabaeidae: Lucanidae) from the Mesozoic of Mongolia, and its position in the system of the superfamily. Paleontological Journal 34:S327-S330.

Nikolajev, G. V. 2000c. A review of species of the genus Hemictenius Rtt. (Coleoptera, Scarabaeidae, Pachydeminae), with the isolation of the new genus Asiactenius. Tethys Entomological Research 2:137-150.

Nikolajev, G. V. 2002a. [To possible assignment of a new genus of Lamellicorn beetles from the Lower Cretaceous of Mongolia to the subfamily Pleocominae]. Paleontologicheskii Zhurnal 2002: 51-55. English translation: Paleontological Journal 36:279-282, 2002. [In Russian.].

Nikolajev, G. V. 2002b. A description of the larva of the genus Eubolbitus Reitter (Coleoptera, Scarabaeidae, Bolboceratinae). Euroasian Entomological Journal 1:207-209. [In Russian.].

Nikolajev, G. V. 2003. [The taxonomic composition of the subfamily Bolboceratinae (Coleoptera, Scarabaeidae) from Palaearctic faunistic region]. Tethys Entomological Research 8:187-206. [In Russian.].

Nikolajev, G. V. 2005a. Omorgini (Coleoptera, Scarabaeidae, Troginae)-a new tribe of scarab beetles. Euroasian Entomological Journal 4:321-322. [In Russian.]

Nikolajev, G. V. 2005b. [Scaraboid beetles of the subfamily Glaphyrinae (Coleoptera, Scarabaeidae) from the Lower Cretaceous of Transbaikalia]. Zvivotniy Mir Dal'nego Vostoka [Animal World of the Far East] 5:69-78. [In Russian.]

Nikritin, L. M. 1977. Infraotryad Scarabaeiformia. In: Mezozoiskie zhestkokrylye. L. V. Arnol'di, V. V. Zherikhin, L. M. Nikritin, and A. G. Ponomarenko (eds.). Trudy Paleontologicheskogo Instituta Akademiya Nauk SSSR, 161(b):119-130.

Ocampo, F. C. 2006. Phylogenetic analysis of the scarab family Hybosoridae and monographic revision of the New World subfamily Anaidinae (Coleoptera: Scarabaeoidea). 3. Phylogenetic analysis of the subfamily Anaidinae (Coleoptera: Scarabaeoidea). Bulletin of the University of Nebraska State Museum 19:13-177.

Ohaus, F. 1912a. Revision der Adoretini. (Col. Lamell. Rutelin.). Deutsche Entomologische Zeitschrift 1912:141-156, 267-282, 411-426, 509-524, 625-643.

Ohaus, F. 1912b. Beiträge zur Kenntnis der Ruteliden. X. Stettiner Entomologische Zeitung 73:273-319, 1 plate. 
Ohaus, F. 1918. Scarabaeidae: Euchirinae, Phaenomerinae, Rutelinae. Coleopterorum Catalogus 20:1-241. [Dated 1915.]

Olivier, A. G. 1789. No. 7 Hexodon [pp. 4]. In: Entomologie, ou Histoire Naturelle des Insectes, avec Leurs Caractères Génériques et Spécifiques, leurs Description, leur Synonymie, et leur Figure Enluminée. Coléoptères, volume 1. Baudouin, Paris, France.

d'Orbigny, H. 1896. Synopsis de aphodiens d'Europe et du basin de le Méditerranée. L'Abeille Journal d'Entomology 28:197-271.

d'Orbigny, H. 1915. Synopsis d'un genre nouveau d'Oniticellides (Scarabaeidae Coprini) special a Madagascar. Annales de la Société Entomologique de France 84:402-434.

Ordóñez Reséndiz, M., and A. C. Deloya. 2004. New Mexican state record for Ataenius texanus Harold (Coleoptera: Scarabaeidae: Aphodiinae, Eupariini). Coleopterists Bulletin 58:20.

Pakaluk, J., S. A. Slipinski, and J. F. Lawrence. 1994. Current classification and familygroup names in Cucujoidea (Coleoptera). Genus 5:223-268.

Parry, F. J. S. 1864. A catalogue of lucanoid Coleoptera; with illustrations and descriptions of various new and interesting species. Transactions of the Entomological Society of London (series 3) 2:1-113.

Parry, F. J. S. 1870. A revised catalogue of the lucanoid Coleoptera; with remarks on the nomenclature, and descriptions of new species. Transactions of the Entomological Society of London 1870:53-118.

Paucar-Cabrera, A. 2005. A catalog and distributional analysis of the Rutelinae (Coleoptera: Scarabaeidae) of Ecuador. Zootaxa 948:1-92.

Paulian, R. 1959. Un nouveau coleoptere scarabeide de Madagascar type d'une nouvelle sous-famille. Le Naturaliste Malgache 10:39-46. [Dated 1958.]

Paulian, R. 1984. Les Orphnidae Américains (Coléoptères, Scarabaeoidea). Annales de la Société Entomologique de France 20:65-92.

Paulian, R., and A. Descarpentries. 1982. Insectes Coléoptères. Cetoniidae Euchroeina. 1. Systématique. Fauna de Madagascar 57:1-67.

Pereira, F. S., and A. Martínez. 1956. Algunas notas sinonimicas en Phanaeini (Col. Scarabaeidae, Coprinae). Revista Brasileira de Entomologia 5:229-239.

Péringuey, L. 1901. Descriptive catalogue of the Coleoptera of South Africa. Fam. Lucanidae. Fam. Scarabaeidae. Sub-families: Coprinae, Aphodiinae, Troginae, Chironinae, Geotrupinae, Hybosorinae, Orphninae, Dynastinae. Transactions of the South African Philosophical Society 12:1-560.

Péringuey, L. 1902. Descriptive catalogue of the Coleoptera of South Africa. Fam. Scarabaeidae. Sub-families: Rutelinae, Hopliinae. Transactions of the South African Philosophical Society 12:561-896.

Péringuey, L. 1904. Descriptive catalogue of the Coleoptera of South Africa. Fam. Lucanidae. Fam. Scarabaeidae. Sub-families: Sericinae, Melolonthinae, Trichiinae, Valginae, Cetoniinae. Transactions of the South African Philosophical Society $13: 1-288$.

Péringuey, L. 1907. Descriptive catalogue of the Coleoptera of South Africa. Fam. Lucanidae. Fam. Scarabaeidae. Sub-families: Sericinae, Melolonthinae, Trichiinae, Valginae, Cetoniinae. Transactions of the South African Philosophical Society 13:289-546.

Petrovitz, R. 1968. Neue Tanyproctus- und Atanyproctus-Arten (Pachydemini, Melolonthinae, Scarabaeidae). Entomologische Arbeiten aus dem Museum Frey 19:237-247.

Philippi, R. A. 1866. Einige Insekten von Chile. Stettiner Entomologische Zeitung 27:109-117.

Pittino, R. 1985. Insects of Saudi Arabia Coleoptera Scarabaeoidea: a revision of the family Aphodiidae. Fauna of Saudi Arabia 6:267-360. [Dated 1984.].

Pittino, R., and G. Mariani. 1986. A revision of the Old World species of the genus Diastictus Muls. and its allies (Platytomus Muls., Pleurophorus Muls., Afrodiastictus n. gen., Bordatius n. gen.) (Coleoptera, Aphodiidae, Psammodiini). Giornale Italiano di Entomologia 3:1-165. 
Portevin, G. 1931. Histoire Naturelle des Coléoptères de France. Tome II Polyphaga: Lamellicornia, Palpicornia, Diversicornia. Encyclopédie Entomologique 13:1-542.

Potts, R. W. L. 1974. Revision of the Scarabaeidae: Anomalinae 1. The genera occurring in the United States and Canada (Coleoptera). Pan-Pacific Entomologist 50:148-154.

Potts, R. W. L. 1977a. Revision of the Scarabaeidae: Anomalinae 2. An annotated checklist of Anomala for the United States and Canada (Coleoptera). Pan-Pacific Entomologist 53:34-42.

Potts, R. W. L. 1977b. Revision of the Scarabaeidae: Anomalinae 3. A key to the species of Anomala of America north of Mexico (Coleoptera). Pan-Pacific Entomologist 53:129-134.

Pouillaude, I. 1916. Les Cétonides Malgaches. Insecta Revue Illustrée d'Entomologie 6:49-75.

Rakovič, M. 1987. A revision of the genus Odochilus Harold with remarks on the tribal classification of the subfamily Aphodiinae (Coleoptera, Scarabaeidae). Acta Entomologica Bohemoslovaca 84:27-44.

Ratcliffe, B. C. 1991. The scarab beetles of Nebraska. Bulletin of the University of Nebraska State Museum 12:1-333.

Ratcliffe, B. C., M. L. Jameson, and A. B. T. Smith. 2002. Scarabaeidae Latreille 1802, chapter 34. In: American Beetles. Volume 2. R. H. Arnett, M. C. Thomas, P. E. Skelley, and J. H. Frank (eds.). CRC Press, Boca Raton, FL.

Reichensperger, A. 1915. Myrmekophilen und termitophilen aus Natal und Zululand. Meddelanden från Göteborgs Musei Zoologiska Afdelning 5:1-20.

Reitter, E. 1892. Bestimmungs-Tabelle der Lucaniden und coprophagen Lamellicornen des palaearctischen Faunengebietes. Verhandlungen des Naturforschenden Vereins in Brünn 24:1-230.

Reyes Novelo, E., and M. A. Morón. 2005. Fauna de Coleoptera Melolonthidae y Passalidae de Tzucacab y Conkal, Yucatán, México. Acta Zoológica Mexicana 21:15-49.

Ritcher, P. O. 1966. White Grubs and Their Allies. Oregon State University Press, Corvallis.

Sabatinelli, G., and G. Pontuale. 1998. Melolonthinae and Pachydeminae of Arabia (Coleoptera: Scarabaeoidea: Melolonthidae). Fauna of Arabia 17:107-146.

Samouelle, G. 1819. The Entomologist's Useful Compendium. Thomas Boys, London, U.K..

Sanmartín, I. 2003. Dispersal vs. vicariance in the Mediterranean: historical biogeography of the Palearctic Pachydeminae (Coleoptera, Scarabaeoidea). Journal of Biogeography 30:1883-1897.

Sanmartín, I., and F. Martin-Piera. 2003. First phylogenetic analysis of the subfamily Pachydeminae (Coleoptera, Scarabaeoidea, Melolonthidae): The Palearctic Pachydeminae. Journal of Zoological Systematics and Evolutionary Research 41:2-46.

Saylor, L. W. 1935. A new genus and two new species of Coleoptera from California (Scarabaeidae). Pan-Pacific Entomologist 11:132-134.

Schaum, H. R. 1845. Observations critiques sur la famille des lamellicorns mélitophiles. Annales de la Société Entomologique de France 2:333-426, plate 10. [Dated 1844.]

*Schaum, H. R. 1848. Verzeichnis der Lamellicornia Melitophila. Stettin, Poland.

Schenkling, S. 1921. Scarabaeidae: Cetoninae. Coleopterorum Catalogus 72:1-431.

Schenkling, S. 1922. Scarabaeidae: Trichiinae, Valginae. Coleopterorum Catalogus 75:1-58.

Schmidt, A. 1910. Coleoptera Lamellicornia, fam. Aphodiidae Genera Insectorum 110:1-155, 3 plates.

Schmidt, A. 1916. Namenänderungen und Beschreibung neuer Aphodiinen (Col.). Archiv für Naturgeschichte 82(A) 1:95-116.

Schoch, G. 1894. Ueber die Systematik der Cetoniden. Mittheilungen der Schweizerischen Entomologischen Gesellschaft 9:164-225.

Schoch, G. 1895. Die Genera und Species meiner Cetonidensammlung. I. Teil: Goliathidae, Gymnetidae, Madagassae, Schizorrhinidae. Zürcher \& Furrer, Zürich.

Schönherr, C. J. 1817. Synonymia Insectorum, oder Versuch einer Synonymie aller bisher bekannten Insecten; nach Fabricii Systema Eleutheratorum etc. geordnet. Erster Band. Eleutherata oder Käfer. Dritter Theil. Bruzelius, Upsala. pp 97-506.

Scholtz, C. H. 1991. Nomenclatural changes in the Ochodaeidae (Coleoptera: Scarabaeoidea). Coleopterists Bulletin 45:30. 
Scholtz, C. H., D. d'Hotman, A. V. Evans, and A. Nel. 1988. Phylogeny and systematics of the Ochodaeidae (Insecta: Coleoptera: Scarabaeoidea). Journal of the Entomological Society of South Africa 51:207-240.

Scopoli, J. A. 1763. Entomologia Carniolica Exhibens Insecta Carnioliae Indigena et Distributa in Ordines, Genera, Species, Varietates. Methodo Linnaeana. Trattner, Vienna, Austria.

Scopoli, J. A. 1777. Introductio ad Historiam Naturalem Sistens Genera Lapidum, Plantarum et Animalium Hactenus Detecta, Caracteribus Essentialibus Donata, in Tribus Divisa, Subinde ad Leges Naturae. Wolfgangum Gerle, Prague.

Scriba, L. G. 1790. Verzeichnis der Insekten in der Darmstadter Gegend. Journal für die Liebhaber der Entomologie 1:40-73.

Semenov-Tian-Shanskij, A. 1889. Diagnoses Coleopterorum novorum ex Asia Centrali et Orientali. Horae Societatis Entomologicae Rossicae 24:193-226.

Semenov-Tian-Shanskij, A. 1895. Coleoptera Asiatica nova VI. Horae Societatis Entomologicae Rossicae 29:336-362.

Semenov-Tian-Shanskij, A., and A. Reichardt. 1925. De novo peculiari Aphodiinorum genere, tribum propriam formante (Coleoptera, Scarabaeidae). Revue Russe d'Entomologie 19:83-88.

Sharp, D. 1873. Description de nouveaux genres et de nouvelles espèces de Coléoptères Lamellicornes. Revue et Magasin de Zoologie (3)1:262-273.

Sharp, D. 1877. Descriptions of some new forms of aberrant Melolonthini from Australia forming a distinct subtribe (Systellopides). Annali del Museo Civico di Storia Naturale di Genova 9:311-320.

Sharp, D. 1899. Insects, part II. In: The Cambridge Natural History, volume 6. S. F. Harmer and A. E. Shipley (eds.). MacMillan and Company, London, U.K.

Sherborn, C. D. 1922. Index Animalium. Part I. Introduction, Bibliography and Index A-Aff. The British Museum, London, U.K.

Sigwalt, B. 1987. Promacropoides bertrandi: nouveau genre et nouvelle espèce de Rutelidae Heterosternina d'Equateur (Coleoptera, Scarabaeoidea). Revue Française d'Entomologie (N. S.) 9:13-15.

Skelley, P. E., and R. D. Gordon. 2002. Scarabaeidae Latreille 1802: Aphodiinae Leach 1815, chapter 34-I. In: American Beetles. Volume 2. R. H. Arnett, M. C. Thomas, P. E. Skelley, and J. H. Frank (eds.). CRC Press, Boca Raton, FL.

Smith, A. B. T., and A. V. Evans. 2005. A supplement to the checklist of the New World chafers (Coleoptera: Scarabaeidae: Melolonthinae) with notes on their tribal classification. Zootaxa 1032:29-60.

Smith, A. B. T., D. C. Hawks, and J. M. Heraty. 2006. An overview of the classification and evolution of the major scarab beetle clades (Coleoptera: Scarabaeoidea) based on preliminary molecular analysis. Coleopterists Society Monographs 5:35-46.

Smith, A. B. T., and M. A. Morón. 2003. Revision and phylogenetic analysis of the Central American endemic genus Phalangogonia Burmeister (Coleoptera: Scarabaeidae: Rutelinae: Anoplognathini. Systematic Entomology 28:323-338.

Smith, T. R. 2005. Observations on the habitat preferences of Auperia denominata Chevrolat (Scarabaeidae: Aphodiinae: Eupariini). Coleopterists Bulletin 59:256-257.

Soula, M. 1998. Rutelini 2. Revision des Anthicheirina 1. Les Coléoptères du Monde 26:1-116.

Stebnicka, Z. T. 1977. A revision of the world species of the tribe Aegialiini. Acta Zoologica Cracoviensia 22:397-506.

Stebnicka, Z. T. 1997. A new genus and species of Eupariini from Argentina (Coleoptera: Scarabaeoidea: Aphodiinae). Acta Zoologica Cracoviensia 40:71-73.

Stebnicka, Z. T. 1999. Lomanoxia Martinez, 1951, and a new tribe Lomanoxiini with notes on comparative morphology (Coleoptera: Scarabaeoidea: Aphodiinae). Acta Zoologica Cracoviensia 42:279-286.

Stebnicka, Z. T. 2001a. A revision of the Neotropical species of Saprosites Redtenbacher, 1858 (Insecta: Coleoptera: Scarabaeidae: Aphodiinae: Eupariini). Entomologische Abhandlungen Staatliches Museum für Tierkunde Dresden 59:221-242. 
Stebnicka, Z. T. 2001b. The New World species of Ataenius Harold, 1867. I. Revision of the $A$. crenator-group, A. nugator-group and $A$. perforatus-group (Coleoptera: Scarabaeidae: Aphodiinae: Eupariini). Acta Zoologica Cracoviensia 44:253-283.

Stebnicka, Z. T. 2002a. The New World species of Ataenius Harold, 1867. II. Revision of the West Indian A. terminalis-group (Coleoptera: Scarabaeidae: Eupariini). Acta Zoologica Cracoviensia 45:259-281.

Stebnicka, Z. T. 2002b. The New World Eupariini: revision of the genus Auperia Chevrolat, 1864 (=Phalangochaeta Martinez, 1952) (Coleoptera: Scarabaeidae: Aphodiinae). Revue Suisse de Zoologie 109:741-775.

Stebnicka, Z. 2003a. Revision and hypothetical phylogenetic analysis of the species of the New World genus Ataeniopsis (Coleoptera: Aphodiinae: Eupariini). European Journal of Entomology 100:101-113.

Stebnicka, Z. 2003b. The New World species of Ataenius Harold, 1867. III. Revision of the A. imbricatus-group sensu lato (Coleoptera: Scarabaeidae: Aphodiinae: Eupariini). Acta Zoologica Cracoviensia 46:219-249.

Stebnicka, Z. T. 2003c. The genus Paraplesiataenius Chalumeau, with descriptions of two new species from Brazil (Coleoptera: Scarabaeidae: Eupariini). Coleopterists Bulletin 57:444- 450 .

Stebnicka, Z. T. 2004. The New World species of Ataenius Harold, 1867. IV. Revision of the A. strigicauda-group (Coleoptera: Scarabaeidae: Aphodiinae: Eupariini). Acta Zoologica Cracoviensia 47:211-228.

Stebnicka, Z. T. 2005a. A new species of Saprosites Redtenbacher from North Island, New Zealand, with phylogenetic implications (Coleoptera, Aphodiinae, Eupariini). New Zealand Journal of Zoology 32:47-51.

Stebnicka, Z. T. 2005b. A second species of Selviria Stebnicka from Brazil (Coleoptera: Scarabaeidae: Eupariini). Coleopterists Bulletin 59:23-25.

Stebnicka, Z. T., and P. K. Lago. 2005. The New World species of Ataenius Harold, 1867. V. Revision of the A. strigatus group (Scarabaeidae: Aphodiinae: Eupariini). Insecta Mundi 19:55-83.

Stebnicka, Z. T., and H. F. Howden. 1995. Revision of Australian genera in the tribes Aphodiini, Aegialiini and Proctophanini (Coleoptera: Scarabaeidae: Aphodiinae). Invertebrate Taxonomy 9:709-766.

Stebnicka, Z. T., and H. F. Howden. 1996. Australian genera and species in the tribes Odontolochini, Psammodiini, Rhyparini, Stereomerini and part of the Eupariini (Coleoptera: Scarabaeidae: Aphodiinae). Invertebrate Taxonomy 10:97-170.

Stephens, J. F. 1831. Description of Chiasognathus grantii, a new lucanideous insect forming the type of an undescribed genus, together with some brief remarks upon its structure and affinities. Transactions of the Cambridge Philosophical Society 4:209-217.

Strand, E. 1928. Nomenclatorische Bemerkungen über einige Coleopteren-Gattungen. Entomologisches Nachrichtenblatt 2:2-3.

Streubel, A. V. 1839. Ueber die Stellung der Brachyelytren oder Staphylinen im natürlichen System (Ein Beitrag zur Classification der Käfer). Isis von Oken 1839:126-137.

Tangelder, I. R. M., and J. Krikken. 1982. Termitophilous scarabs of the tribe Corythoderini: a taxonomic review (Coleoptera: Aphodiidae). Zoologische Verhandelingen 194:1-114.

Vincini, A. M., A. N. López, H. A. Alvarez-Castillo, D. M. Carmona, P. L. Manetti, and M. A. Morón. 2001. Descripción de los estados inmaduros y la hembra de Myloxenoides tandilensis Martínez, 1975 (Coleoptera: Melolonthidae: Melolonthinae: Pachydemini). Elytron 14:39-52. [Dated 2000].

Vulcano, M. A., A. Martínez, and F. S. Pereira. 1961. Eurysternini, nueva tribu de Scarabaeinae (Col. Scarabaeidae). Actas y Trabajos del Primer Congreso Sudamericano de Zoología 3:267-271. [Dated 1960.]

Vulcano, M. A., and F. S. Pereira. 1961. A subfamilia Penichrolucaninae (Col. Lucanidae) representada em América. Studia Entomologica 4:471-480.

Wallace, A. R. 1868. A catalogue of the Cetoniidea of the Malayan Archipelago, with descriptions of the new species. Transactions of the Entomological Society of London (3)4:519-601. 
Wasmann, E. 1918. Myrmecophile und termitophile Coleopteren aus Ostindien, hauptsächlich gesammelt von P. J. Assmuth S. J. II. Scarabaeidae. Wiener Entomologische Zeitung 37:1-23.

Weber, F. 1801. Observationes Entomologicae, Continentes Novorum Quae Condidit Generum Characteres, et Nuper Detectarum Specierum Descriptiones. Bibliopolii Academici Novi, Kiel, Germany.

Westwood, J. O. 1834. Descripto generum nonnullorum novorum e familiâ lucanidarum, cum tabulâ synopticâ familiae notulis illustratâ. Annales des Sciences Naturelles. Zoologie et Biologie Animale (2)1:112-122, plate 7.

Westwood, J. O. 1838. Lucanidarum novarum exoticarum Descriptiones, cum Monographia Generum Nigidii et Figuli. Entomological Magazine 5:259-268.

Westwood, J. O. 1841a. Plate I. Descriptions of some Asiatic cornuted species of Cetoniidae, [pp. 1-6, plate I]. In: Arcana Entomologica; or Illustrations of New, Rare, and Interesting Insects, volume 1. William Smith, London, U.K.

Westwood, J. O. 1841b. Insectorum novorum centuria. Annals and Magazine of Natural History (series 1) 8:203-205.

Westwood, J. O. 1842a. Maechidius, MacL., a genus of Lamellicorn beetles, with descriptions and figures of some new genera belonging to the same tribe. Annals and Magazine of Natural History (series 1) 8:457-458.

Westwood, J. O. 1842b. Plate XIX. Descriptions of some Cetoniidae from tropical Africa [pp. 69-72, plate 19]. In: Arcana Entomologica; or Illustrations of New, Rare, and Interesting Insects, volume 1. William Smith, London, U.K.

Westwood, J. O. 1842c. Plates XXIX and XXX. On the goliathideous Cetoniidae of Asia [pp. 113-122, plates 29-30]. In: Arcana Entomologica; or Illustrations of New, Rare, and Interesting Insects, volume 1. William Smith, London, U.K.

Westwood, J. O. 1842d. Plate XXXII. Illustrations of some species of Cetoniidae from Madagascar [pp. 125-128, plate 32]. In: Arcana Entomologica; or Illustrations of New, Rare, and Interesting Insects, volume 1. William Smith, London, U.K.

Westwood, J. O. 1842e. Plates XXXIII, XXXIV, XXXV, and XXXVI. On the goliathideous Cetoniidae of Asia [pp. 129-141, plates 33-36]. In: Arcana Entomologica; or Illustrations of New, Rare, and Interesting Insects, volume 1. William Smith, London, U.K.

Westwood, J. O. 1843. Plates XLII, XLIII, and XLIV. On the goliathideous Cetoniidae of Africa [pp. 163-176, plates 42-44]. In: Arcana Entomologica; or Illustrations of New, Rare, and Interesting Insects, volume 1. William Smith, London, U.K.

Westwood, J. O. 1845a. Memoir on the Geotrupidae and Trogidae. Annals and Magazine of Natural History (series 1) 15:438-441.

*Westwood, J. O. 1845b. On some exotic species of Aphodiidae. Proceedings of the Entomological Society of London 6:xciii.

Westwood, J. O. 1845c . On the Lamellicorn beetles which possess exserted mandibles and labrum, and 10-jointed antennae (continued). Transactions of the Entomological Society of London 1:155-160.

Westwood, J. O. 1848a. On the Australian species of the Coleopterous genus Bolboceras, Kirby. Proceedings of the Linnean Society of London 1:365-366.

Westwood, J. O. 1848b. Descriptions of some new or imperfectly known species of Bolboceras. Proceedings of the Linnean Society of London 1:384-387.

Westwood, J. O. 1855. Descriptions of some new species of exotic Lucanidae. Transactions of the Entomological Society of London 2:197-221.

Westwood, J. O. 1871. Descriptions of some new exotic species of Lucanidae. Transactions of the Entomological Society of London 1871:353-374.

Westwood, J. O. 1874. Thesaurus Entomologicus Oxoniensis; or, illustrations of new, rare, and interesting insects, for the most part contained in the collections presented to the University of Oxford by the Rev. F.W. Hope, M.A., D.C.L., F.R.S., \&c. with forty plates from drawings by the author. MacMillan and Co., London, U.K.

Westwood, J. O. 1879. A decade of new Cetoniidae. Transactions of the Entomological Society of London 1879:199-208. 
Wheeler, G. 1912. On the dates of the publications of the Entomological Society of London. Transactions of the Entomological Society of London 1911:750-767.

White, A. 1842. Descriptions of some hemipterous insects of the section Heteroptera. Transactions of the Entomological Society of London 3:84-94.

Wood-Mason, J. 1878. Description of Didrepanephorus bifalcifer, the type of a new genus and species of Rutelidae, remarkable for the huge sickle-shaped mandibular horns of the males. Annals and Magazine of Natural History (series 5) 2:422-426.

Woodruff, R. E. 1973. The scarab beetles of Florida (Coleoptera: Scarabaeidae). Part 1. The Laparosticti (subfamilies: Scarabaeinae, Aphodiinae, Hybosorinae, Ochodaeinae, Geotrupinae, Acanthocerinae). Arthropods of Florida and Neighboring Land Areas 8:1-220.

Zunino, M. 1984. Sistematica generica dei Geotrupinae (Coleoptera, Scarabaeoidea: Geotrupidae), filogenesi della sottofamiglia e considerazioni biogeografiche. Bollettino del Museo Regionale di Scienze Naturali Torino 2:9-162. 